(a )es
mit ia
1972

Applications of the

Generalized Information Processing System

( GYPSY)

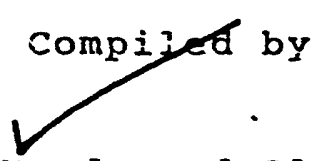

D. W. Moody and Olaf Rays

.

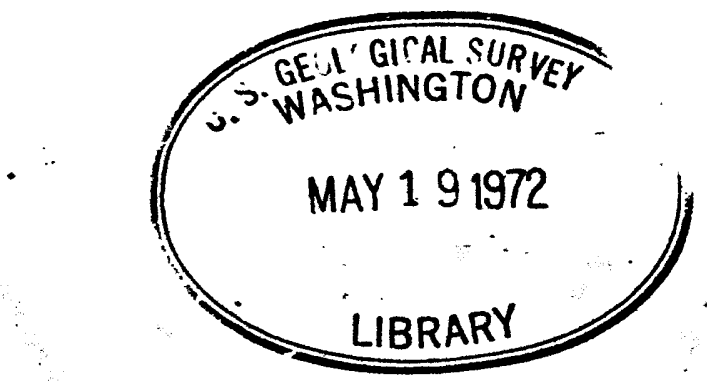

open-file Report , , 23385 72.260

U. S. Geological survey

washington, D. C, 20242

12001
$1771 a$

January 1972 
CONTENTS

Page

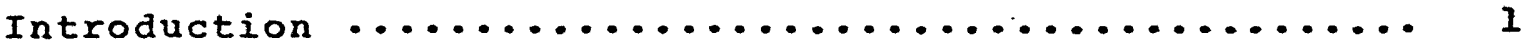

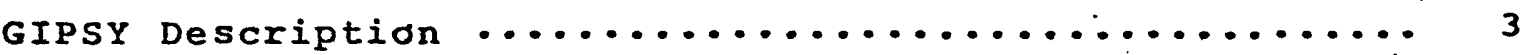

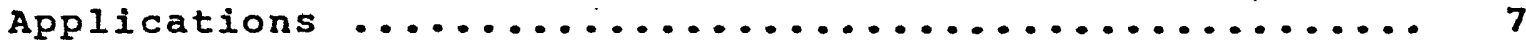

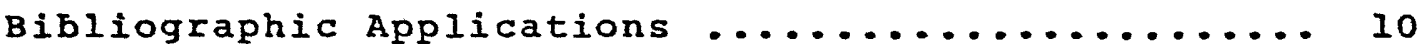

Selected Water Resources Abstracts (OWRR) .... II

Abstracts of North American Geology (USGs) .... 14

Biological Information Retrieval System (NODC). 17

Natural Resources Applications .................. 24

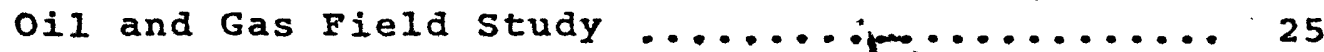

Oil and Gas Field File (OOG) ............. 28

FPC - South Louisiana Area File (OOG) .... 32

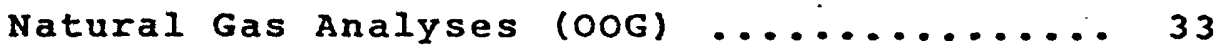

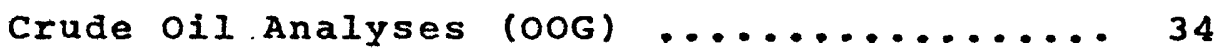

Oil Fieid. Brine Analyses (OOG) ........... 35

Committee on Drilling statistics Well

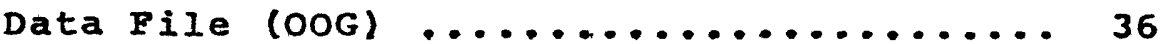

Computerized Resource Information Bank (USGs) • 37

Microprobe Data system (USGs) .............. 42

River Basin Characteristics (USGs) .......... 43

- KRD Blological Data File (USGs) .............46

MRD station File (USGS) .................... 50

Massachusetts Gazetteer (USGs) .............. 53 
CONTENTS

Management Applications

Department of Interior Roster of Field offices

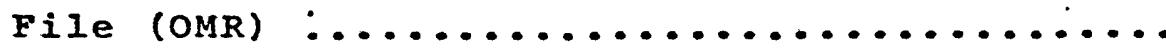

Catalog of Federal Domestic Assistance Program

(OM $\dot{R})$

Grant-in-Aid Program File (OMR)

Working File (OMR)

ocs platform File (USGs)

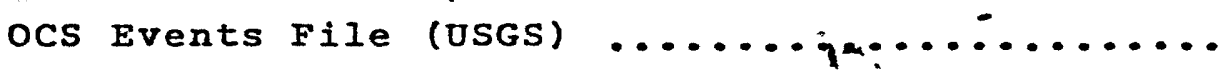

71

WRD Project File (USGS) ..................... 74

Minutes GIPSY Users' Conference ................. 81

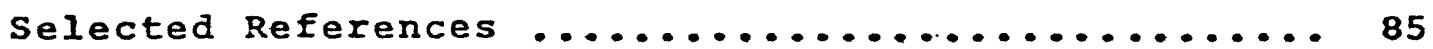




\title{
Applications of the Generalized Information Processing. System (GIPSY)
}

\section{by}

\author{
D. W.. Moody and olaf Kays
}

\section{ABSTRACT}

The Generalized Information Processing system (GIPSY) stores and retrieves variable-field, variable-length records consisting of numeric data, textual data, or codes. A particularly noteworthy feature of GIPSY is its ability to search records for words, word stems, prefixes, ind suffixes as well as for numexic values. Moreover, retrieved records may be printed on pre-defined formats or formatted as fixed-field, fixed-length records for direct input to other-programs, which facilitates the exchange of data with other systems. At present there are some 22 applications of GIPSY falling in the general areas of bibliography, natural resources information, and mariagement science, "This report presents a description of each application including a sample input form, dictionary, and a typical formatted record. It is hoped that these examples will stimulate others to experiment with innovative uses of computer technology. 


\section{INTRODUCTION}

On May 12, 1971, the U. S. Department of Interior sponsored a one-day conference of Generalized Information Processing System (GIPSY) users located in the Washington, D. C. area. During the conference, GIPSY users exchanged experiences and recommended that various extensions and improvements be. made to the GIPSY program. Twenty-two applications of GIPSY were identified during the meeting. These applications fall in the general areas of bibliographic retrieval, natural resources information, and management science.

The Generalized Information processing system was made available to the Department of the Interior by Dr. James $W$. Sweeney and the University of Oklahoma Research Institute in early 1969. GIPSY was first applied to the storage and retrieval of Abstracts of North American Geology. Because of the limited resources of the Geological survey's Computer Center, no attempt was made to publicize GIPSY or ta encourage its use other than to provide manuals upon request. In a sense, this operating environment was a major test of GIPSY's ability to accommodate the users, many of whom were novices in the use of computers. The success of GIPSY is attested to by the fact that the current level of activity has been stimulated primarily by word-of-mouth communication between users and potential users.

During the conference it became apparent that the potential user population in the Department of the Interior 
was much larger than was originally thought. The purpose of this compilation is to acquaint potential users with GIPSY and to describe each of the applications identified at the users' conference. It is hoped that these examples will stimulate further use of GIPSY and the development of new appications.

The final section of this report summarizes the users" recommendations and suggestions for future development of GIPSY. While complete understanding of these suggestions requires a working knowledge of GIPSY, they do indicate some of the types of problems and constrajuts present in the current version of the system.

Acknowledgments. -- It is impossible to thank individually all of the GIPSY users who generously responded to requests for examples of their applications. Obviously this report would not have been possible without their cooperation. Potential users are encouraged to contact the individuals responsible for the specific applications for further information. GIPSY manuals may be obtained from --

Chief, Office of Systems Research and Development

Computer Center Division

U. S. Geological..Survey

Washington, D. C. 20242

(202) 343-8264 
GIPSY Description

The Generalized Information Processing system (GIPSY) was developed at the University of Oklahoma's Merrick Computing Center under the direction of Dr. James W. Sweeney (Addison and others, 1969). The system, written in Basic Assembly Language, utilizes three files: (1) a dictionary consisting of one or more look-up tables (forms) which defines the data element labels and the formats of routine record displays; (2) a dynamic address list of records that meet certain search criteria; (3) the records file containing variable-length, variable-fietä data (figure 1 ). GIPSY is compatible with IBM System/360 computers having a minimum of 65,536 bytes of core storage and 2 IBM/2311 disk drives or equivalent direct access storage. six utility programs are used to build and maintain GIPSY files: (1) CREATE allocates space and pre-formats the file on direct access devices; (2) DBUILD builds forms for the dictionary; (3) RBUILD builds records; (4) UPDATE alters existing records by adding, deleting, or modifying data elements: (5) DUMP creates back-up copies of the file on magnetic tape; and (6) RESTORE loads the files back onto a direct access device.

A GIPSY search is an iterative process that enables the user to make decisions about the course of his search 
GIPSY DATA RETRIEVAL

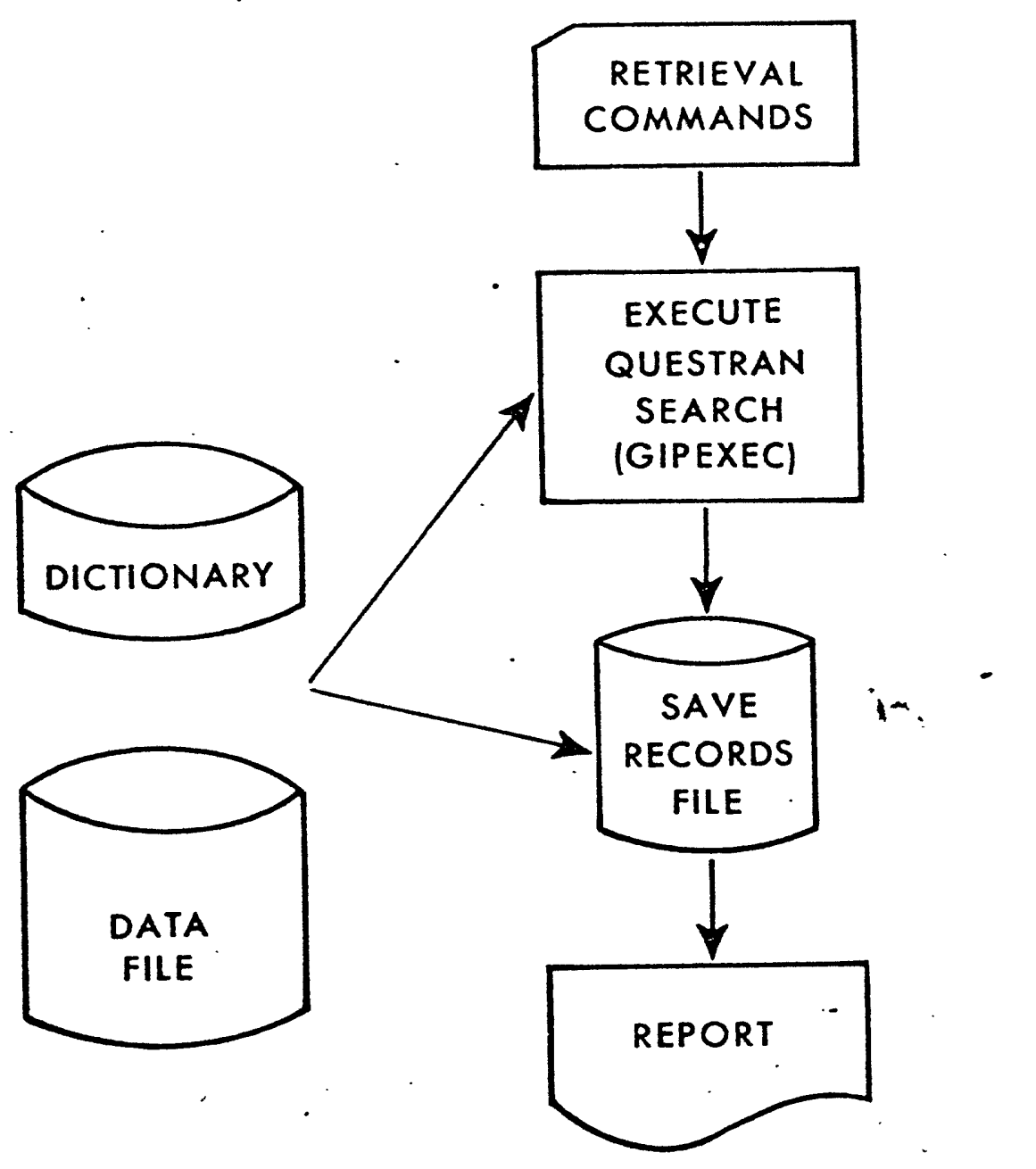

Figure 1. -- Principal components of the Generalized Information Processing system.

4 
at various points during its execution (figure 2). Records are retrieved by using Boolean operators (AND, OR, and NOT) to combine search variables into a logic statement. Text can be searched for particular words, parts of words, phrases, or word ranges; numeric data can be searched by using relational operatois (Equal to, Greater Than, and Less Than). In addition, records can be searched for the presence or absence of specified data elements.

After the search has been completed GIPSY displays the following statistics: (I) The number of records searched; (2) The number of records selected; (3) The number of records in.

which satisfied each search variable; (4) The number of records which satisfied the relationships specified in any additional LOGIC statements. Retrieved records may be sorted on any data item in ascending or descending order before being printed. Records may be printed or transferred to machine-readable form (e.g.. magnetic tape) in any predefined format; or they may be reformatted as fixed-field, fixed-length records at the time of search, thereby enabling the data to be used directly as input to other computer programs. 


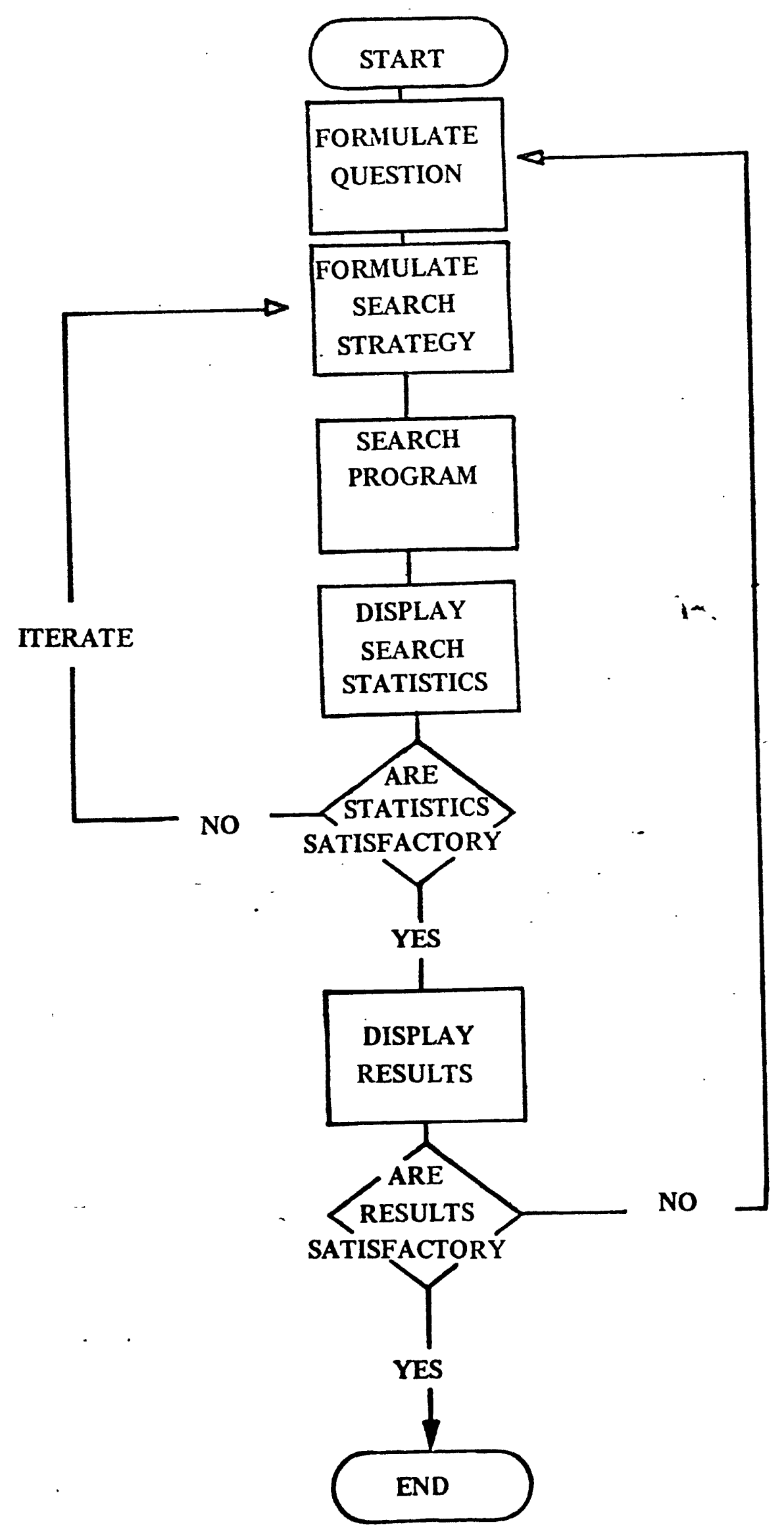

Pigure 2. -- Flow chart of a GIPSy search. 
APPIICATIONS

The 22 applications of GIPSY identified at the GIPSY users' conference are divided into three general areas:

1. Bibliography -- the storage and retrieval of bibliographic citations and in some cases abstracts.

2. Natural resources data -- the storage and retrieval of natural resources data or information usually associated with a set of geographic coordinates.

3. Management science -- the storage and retrieval of information utilized in the mapagement of an organization or an activity.

Most of the application described in this section contains the following elements:

1. Title.-- title or name of the file (or information systems).

2. Sponsor. - name and address of the sponsoring agency.

3. Contact. -- name and telephone number of the individual to contact for more information about the application.

4. Status of application -- each application is classified as follows:

Planned file - the application is being designed.

pilot file - an experimental GIPSY file has been established and the application is being tested. 
Operational file -- the file has been established (or is being implemented) for operational use.

A file, which for one reason or another has been discontinued is listed as inactive. Where possible the reason for a file being inactive is given.

5. Objectives. - the objectives and purpose of the Eile.

6. Source documents. - the sources of information for the file. in.

7. File organization. - a general description of the types of data contained in the file. "Data elements" as used here refers to labels in the GIPSY dictionary.

8. Users. -- the principal users of the file.

9. Size of file. -- the number of records on the file as of september 1970.

10. Problem. - a description of any problems encountered In the design or operation of the file.

In addition to the above information, each application may have one or more of the following illustrations:

1. Plowchart

2. Input document

3. GIPSY dictionary

4. GIPSY record 


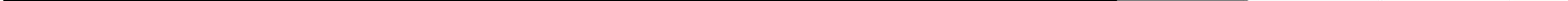


BIBLIOGRAPHIC

APPLICATIONS

in. 
Title: Selected Water Resources Abstracts (SWRA)

Sponsor: U. S. Department of the Interior

Office of Water Resources Research

Water Resources Scientific Information Center

washington, D. C. 20240

Contact: Raymond A. Jensen, (202) 343-8435

Status of application: Operational file

Objectives: To provide archival storage of bibliography and abstracts of water resources literature. The file is used to prepare recurring bibliographic searches.

Source documents: The water Resources Scientific Information Center (WRSIC) prepares a semimonthly publication, Selected Water Resources Abstracts, from documents submitted by subject specialists located at various universities and government agencies throughout the country. The computer file is a by-product of the publication process.

File organization: Each record contains a document accession number, subject field and group code (a classification system devised by the Committee on Water Resources Research, Federal Council for Science and Technology), organization (source), title of publication, authors, project designation, date, citation, descriptors, identifiers, and abstract. Descriptors or controlled index terms are selected from the Water Resources Thesaurus, published by the office of Water Resources Research.

Users: Specialists engaged in water resources research, planning, and management. Included in this group are personnel of approximately 1300 water resource studies conducted by the U. S. Geological survey.

Size of file: Approximately 35,700 records at present. 


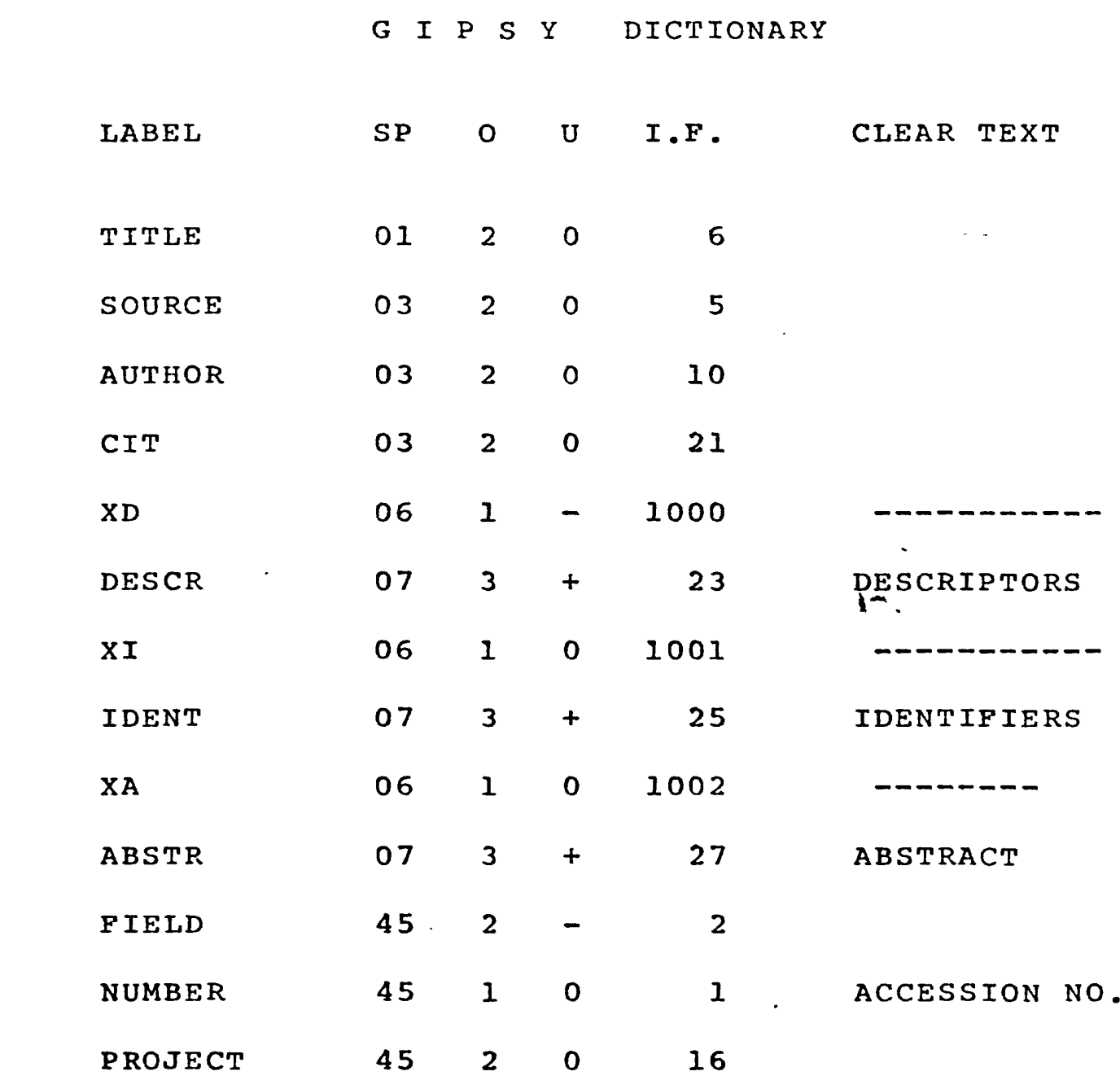

Figure 3. -- GIPSY dictionary for the Selected water Resources Abstracts file. 
SQME RYMGFF PATTERAS IH $\triangle$ PERMAFROST AREA OF NORTHERN CANAOA.

ALBERTA UNIV. DEPARTMENT OF GEOGRADHY, EOMDNTON, CLNAOA.

A. SOHMER, AND E, \$. SPENCE.

ALBERTAM GEOGRADH, NO 4 , PD 60-64, 1969, 5 FIG.

QESCBMPIORS

- permafrost. *melting. *frozen ground. showhelt, claciers.

DRECIPITATIONIATKOSPHERICI. ICE JAMS. STREAMFLOH, DISCHARGE(WATER). HYOROGRAPHS, : SURFACE-GROUNCWATER RELATIONSHIPS, FLUCTUATION, REGIKE. INTERNATICNAL HYOROLOGICAL CECACE. TEMPERATURE.

LEEMIIFIERS

-acjive layer, oimensionless morographs, groung thermal regime. * NOR THWEST TERRITORIES, YELLCWKNIFE RIVER, *CANAOA.

MSIBACI

OIMEMSIONLESS HYOROGRAPHS CF THE YELLOMXNIFE RIVER, "I T, CANAOA, SHOH DEAK RUAOFF IN JULY. THIS IS TOO LAIE TO BE RELATED DIRECTLY TO

SMGYMELT, BECAUSE MEAN NCNTHLY TEMPERATURE FIRST RISES ABOVE FREELING IN MAY. IHE GRAOUAL RISE AND FALL OF OISCHARGE IS NOT LIKE THE ABRUPT RigE ANo FALL ASSOCIATEO WITH SNOWMELT REgIMES. THE PEAK IS TOO LATE TO OE EXPLAINEO BY UPSTREAM ICE BLOCKAGE. PRECIPITATION ANO DISCHARGE DATA FOR 1957-58 INOICATE THAT FLCWS REGIKE IS NOT APPRELIABLY AFFECTED BY THE SUMMER PRECIPITATION PATTERN S OISCHARGE YARIEO LESS THAN I PERCENT. WHILE PRECIPIITATION VARIED BY 300 PERCENT. HIGH FLCWS ARE IN JULY. THE MOTTEST MONTH, WITH A PATTERN SIMILAR TO GLACIAL-MELT STREAM REGIME. THE THERMAL REGIME IN THE ACTIVE PERMAFROST LAYERSIIS. SUGGESTEO AS THE COHTROL OF FLOW REGIME. DATA ARE PRESENTED IN OIMENSIONLESS MYOROGRAPHS, MONTHLY PRECIPITATION GRAPHS, MONTHLY TEMPERATURE GRAPHS. ANO $\triangle$ GRAPH OF GRQYNO THERMAL REGIME.

FiELO O2L

ACCESSTON NO. W68-00018 
Title: Abstracts of North American Geology and Geophysical Abstracts files

Sponsor: U. S. Geological survey

Computer Center Division

Washington, D. C. 20242

Contact: Olaf Kays, (202) 343-8264

Status of application: Operational file (inactive)

Objectives: To provide archival storage of earth sciences bibliography for use in compiling recurring bibliographies and conducting retrospective searches.

Source documents: Magnetic tapes used to prepare Abstracts of North American Geology and Geophysidäi Abstracts.

The existing bibliographic tapes were converted to GIPSY format in 1969. The Geological survey discontinued publication of all bibliographic serials as of December 1971 . Therefore the file is inactive.

File organization: Each record contains the name of the author, date of publication, title, citation, number of illustrations, index terms (U. S. Geological survey, 1967), abstract, and reference number.

Users: Earth scientists in the Geological survey and other Federal agencies.

Size of file: The Abstracts of North American Geology file contains approximately 66,000 citations, about 60 percent of which have abstracts covering the period 1960-1969. The Geophysical Abstracts file contains 24,000 citations, 85 percent of which have abstracts covering the period 1966-1969. 
GI PS Y DICTIONARY BUILD FORM - BIBREC 69298

LABEL SP $O$ U I.F. CLEAR TEXT

AUTHOR $042-00100$

DATE $\quad 06 \quad 2 \quad 0 \quad 00110$

in

TITLE $061+00060$

REFER $06 \quad 2 \quad 0 \quad 00220$

ILLUS 08200400

SCORA 091000229

TERMS $103+.00230$ INDEX TERMS

SCORB 091 - 00269

ABSTR $103+00270$ ABSTRACT

$\begin{array}{llllll}\text { NUMBER } & 09 & 1 & 0 & 00010 & \text { REFERENCE NO. }\end{array}$

Migure 3. -- GI8SY dictionary for the Abstracts of North Amarlcan Goology and Geophysical Abstracts 


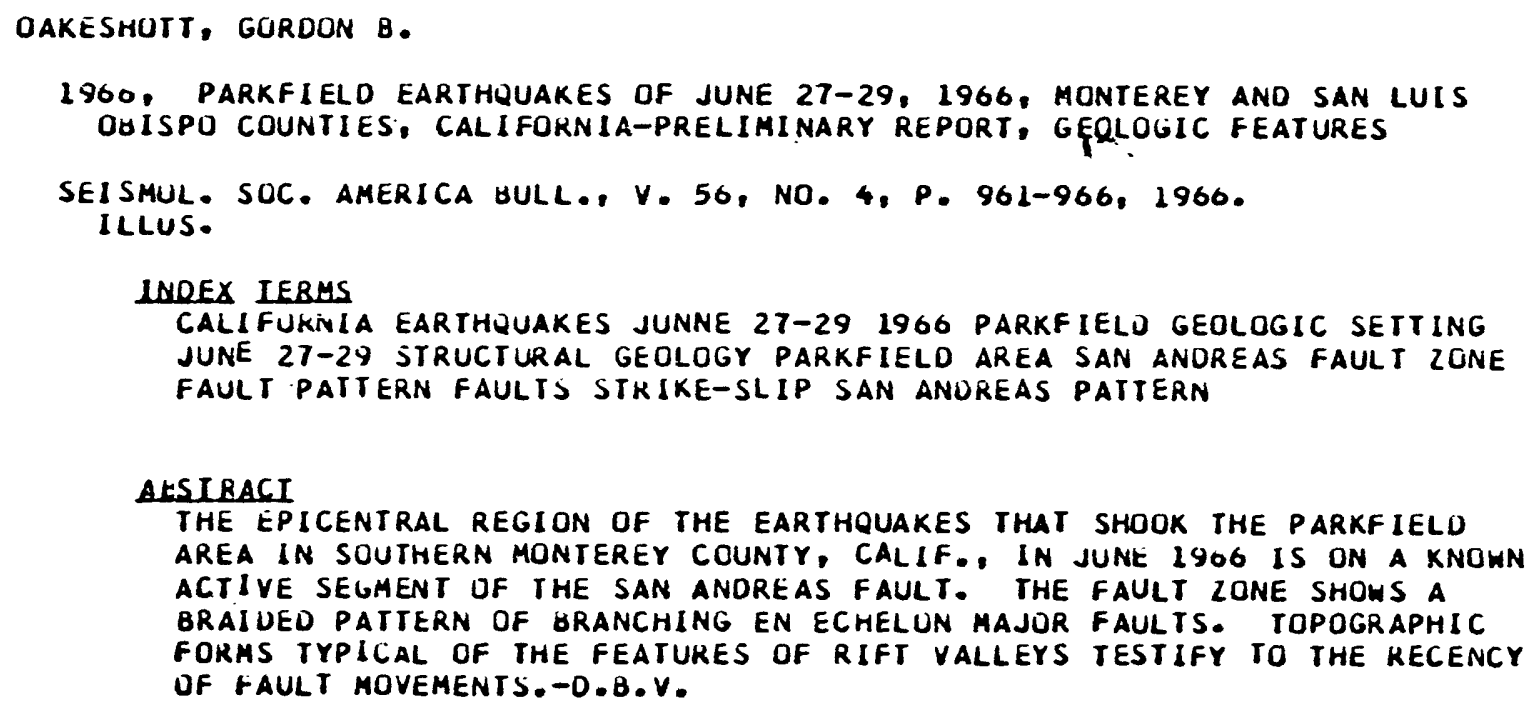

REFERENCE NO. NAB6605528 Figure 6. - GIPSI record from the Abstracts of North
American Geology file. 
Title: Biological Information Retrieval system

Sponsor: National Oceanic and Atmospheric Administration National Oceanographic Data Center

Rockville, Maryland 20852

Contact: Dr. Elaine V. Collins, (202) ox 3-3782

Status of application: Operational file

Objectives: To provide archival storage of marine biology bibliography for use in answering requests for information.

Source documents: NODC receives documents by subscription, or exchange, or on loan from NOAA Library Documents are checked for pertinence to the scope of the file and assigned descriptors from a thesaurus developed by NODC.

The file has been restricted to the following subject areas :

A. Topics of major interest:

Distribution; ecology: sampling techniques of phytoplankton, zooplankton, and benthos; analysis techniques: growth culture techniques; productivity: particulate and dissolved organic matter; food chains; nutrient cycles; biodeterioration.

B. Topics of lesser interest (limited files):

Microbiology; pollution: aquaculture; bioluminescence; noxious and poisonous organisms; medicinal uses of aquatic products; deep scattering layer.

c. Excluded topics (unless directly pertinent to any topic abovel:

Physiological studies; genetics; fish or shellfish stock assessment; vertebrate anatomy and taxonomy: behavioral studies.

Each pertinent document is checked against an author file for possible duplication. If it is a new item (A) a 
bibliographic citation card is typed and placed in the author file, and (B) the complete citation is typed on an index sheet (sample attached).

The document and index sheet are given to an indexer who reads the document and assigns appropriate descriptors for subject (based on a thesaurus developed in-house); for area (by general area, e.g.. North Atlantic ocean, and Marsden square and quadrant); and for taxonomy (genus name, and higher taxonomic names assigned for each phylum generally based on FAO classification).

File organization: Data elements include an accession number, year of publication, authors, title, citation, general geographic location, marsden squares covered by report contents, subject codes, subject descriptors, and taxonomic descriptors. Descriptors are from a controlled list.

Users: This file will be used primarily by Nódc staff engaged in responding to requests for information from other Federal agencies, universities, industry, and the general public.

Size of file: Approximately 9,000 records at present. 

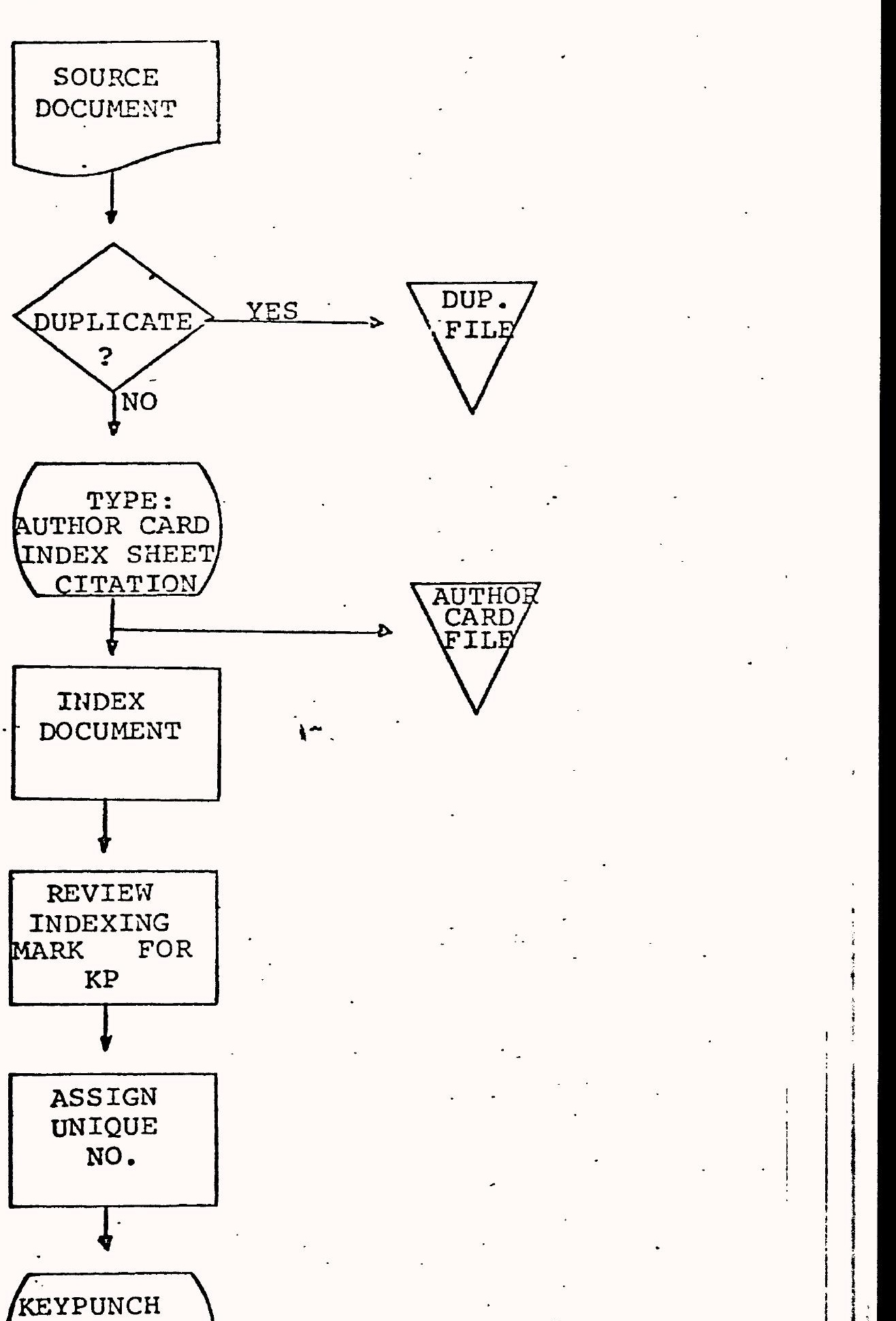
ASSIGN
UNIQUE
No.

Pigure 7. - Flow chart of

the Biological Information Retrieval system.
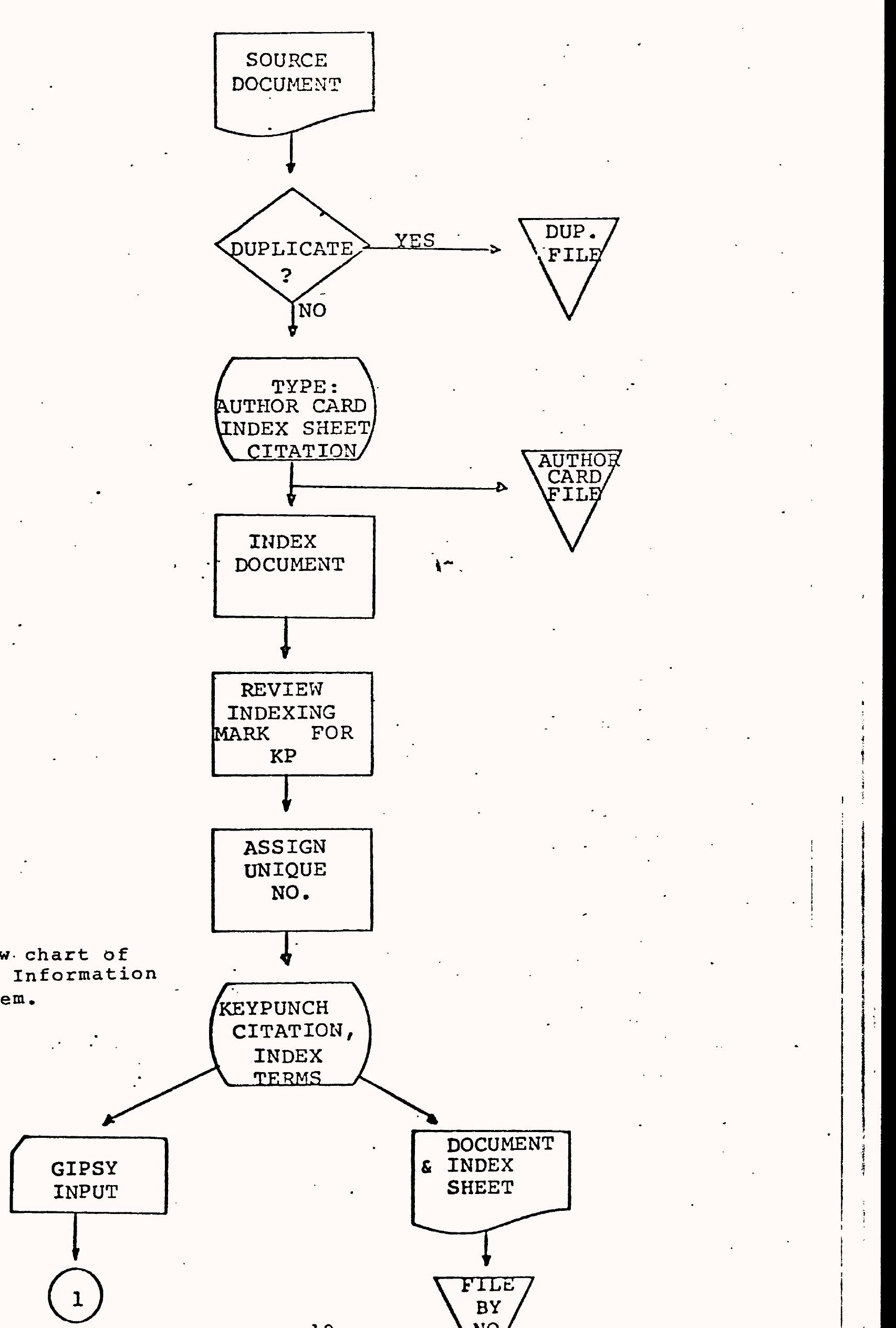

CITATION

INDEX

TFRMS

DOCUMENT

\& INDEX

SHEET
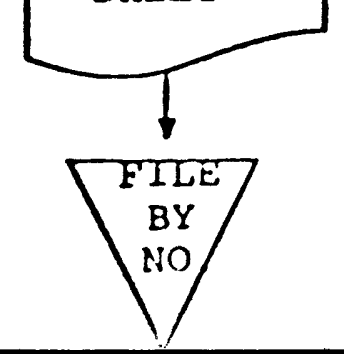
NODC BIOLOGICAL INFORMATION RETRIEVAL SYSTEM

LIBRARY

ACCESSION NO. $\quad \underline{A}<\mathrm{N} \quad 8979 \geq$ YEAR $B<.1957 \quad \geq$

AUTHORS $\subseteq<$ HENRY, D. P.

TITLE D $\quad$ SOME LITTORAL BARNACLES FROM THE TUAMOTU, MARSHALL AND CAROLINE ISLANDS

CITATION E< PROC. U. S. NAT. MUS., SMITHSON. INST. $107(3381)$, $25-38$.

GENERAL AREA $F<A R ;$ NW NE; SW; SE; NA; SA; IN; AN; $\mathrm{BL} ; \quad \mathrm{ME}>$

MARSDEN SQUARES $G<\quad 019-0 \cdot 020-3 \quad 020-4 \quad 020-0 \quad 022-3 \cdot 022-0$

$\mathrm{H}<\mathrm{SC}-\quad \mathrm{TX}$

DT

Figure 8. -- Input document for lod Biological Information Retrieval system.

DO NOT PUNCH

INDEXER

DATE REC'D

DATE INDEXED

REVIEWER

DATE REV'D 


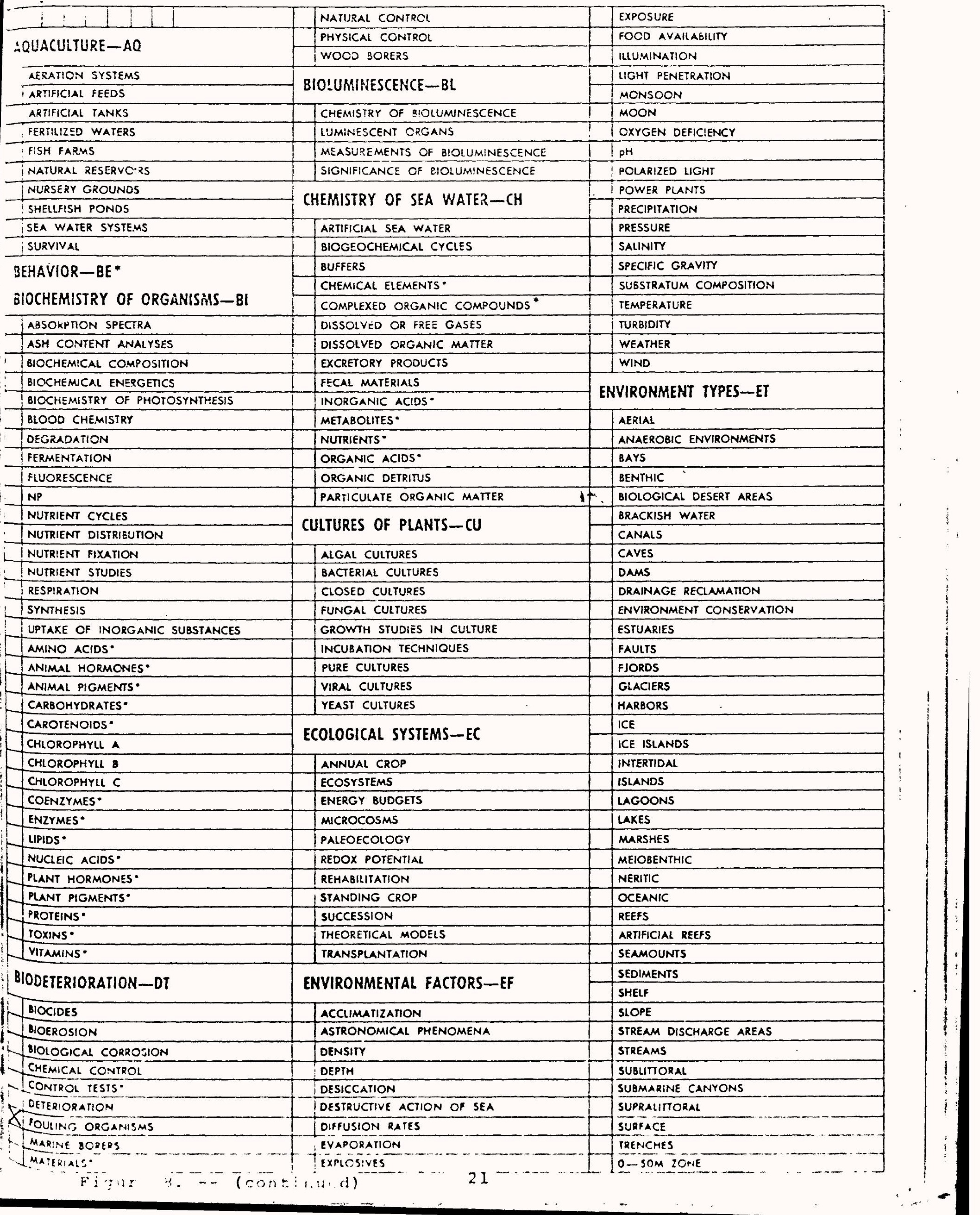




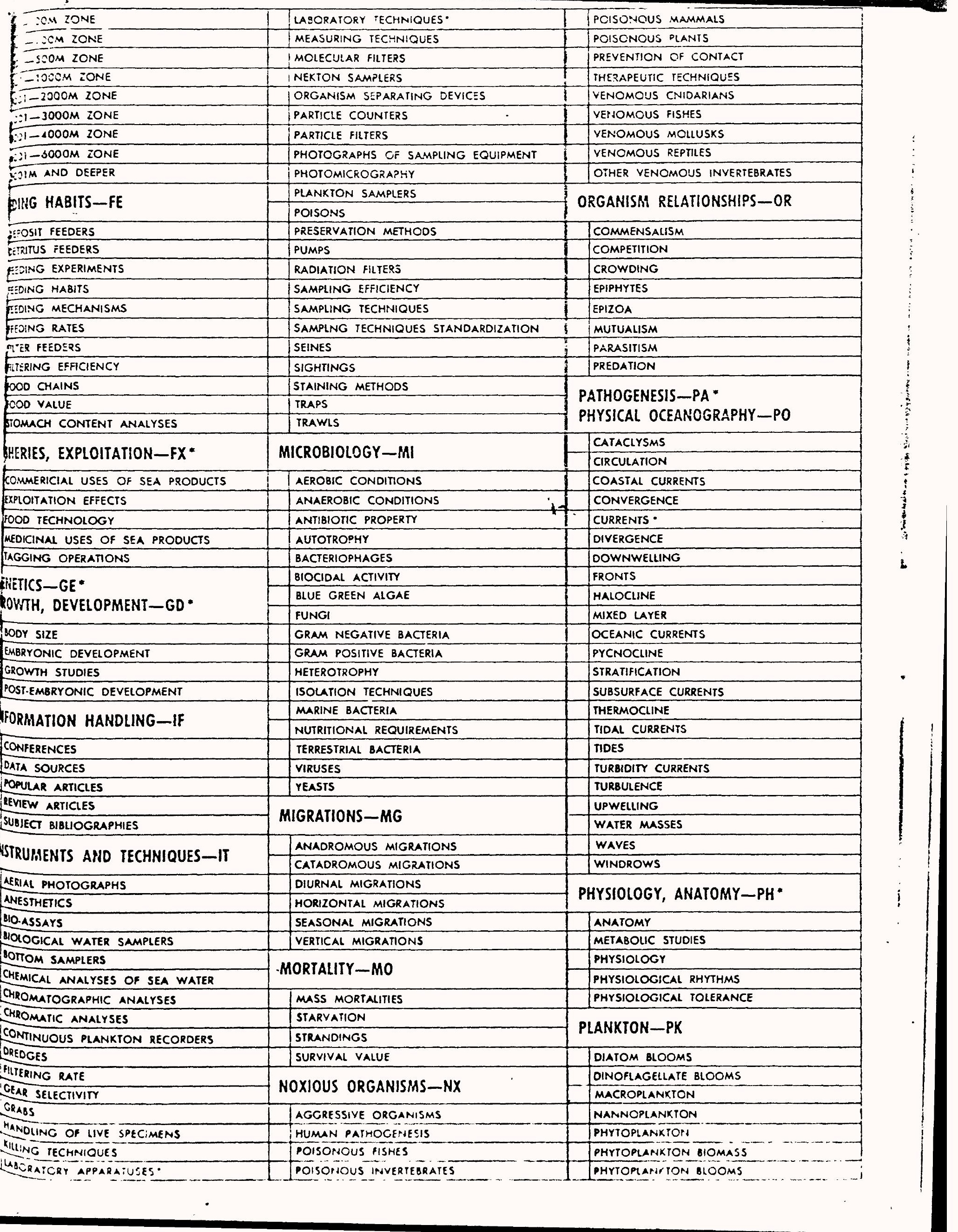


MTTOPLANKTO:- POPULATION DENSITY

TANKTON MEASUREMENTS

- iedimENTATION kate

ip DIAGRAMS

MIRAPLANKTON

:OOPLANKTON

:OCPIANKTON BIOMASS

:OOFLANKTON DLOOMS

OOOPLANKTON POPULATION DENSITY

WILUTION-PL

300

NDUSTRIAL YASTES

MAN-MADE PCLIUTION

VATURAL POLLUTION

POLIUTION CONTROL

SEWAGE

OOXIC BLOOMS

iOXIOIT

WASTE TREATMENT

WATER QUALITY

IPULATION DISTRIBUTION-PD

AGGREGATIONS

IENTHIC BIOMASS

BENTHIC POPULATION DENSITY

BENTHOS

COLONIZATION

COMMUNITY COMPOSITION

DISPERSAL

DIURNAL DISTRIBUTION

DURNal Variations

DOMINANT SPECIES

FACTORS CONTROLLING DISTRIBUTION

ZONATION

PRODUCTIVITY_PR

ADDITICNAL TERMS

ICARSON-14 METHOD

CARBON-CHLOROPHYLL RATIO

D DALIY GROSS PRODUCTION

ILLUMINATION TECHNIQUES

LIGHT-PS

NON-STANDARD PRODUCTIVITY

NUTRIENT DEPLETION METHOD

OXYGEN METHOD

PH METHOD

PHOTOSYNTHETIC PERIODICITY

PHOTOSYNTHETIC RATES

PIGMENT CONCENTRATIONS

PIGMENT DISTRIBUTION

PIGMENT METHOD

PS-R

RADIATION BIOLOGY-RA*

RADIOISOTOPES-RI*

RADIOISOTOPE LABELING

RADIOISOTOPE TAGGING

RADIOISOTOPE UPTAKE

GEOGRAPHICAL DISTRIBUTION

NDICATOR SFECIES

MNFORMATION THEORY

LUEE CYCLES

ULE EXPECTANCY

MATHEMATICAL DESCRIPTIONS

MEIOBENTHOS

WCROBIAL BIOMASS

wCrosial population density

REPRODUCTION BIOLOGY-RE*

RESEARCH PLATFORMS-RP *

SONIC PHENOMENA-SP*

DEEP SCATERING LAYERS

SOUND SCATTERING

STATISTICS, COMPUTATIONS-ST

CHI SQUARE TESTS

COMPUTER ANALYSES

QUALITY CONTROL

SAMPLING DISTRIBUTION

STATISTICAL ANALYSES

TABLES FOR REDUCTION ANO COMPUTATION

TAXONOMY - TX

WCRODISTRIBUTION

NEKTONIC BIOMUSS

NEKTONIC POPULATION DENSITY

NEUSTON

BAiCMINESS

MeUston

population isolation

population stability

KPIACEMENT RATES

SAMPIING FOR CENSUSES.SURVEYS

Broors

EASONAL DISTRIBUTION

fasonal variations

Dital oistrieutión

CHECKLISTS

COLOR PATTERNS

FIELO IDENTIFICATION

NOMENCLATURE

POLYMORPHISM

RACE STUDIES

SEROLOGICAL TAXONOMY

TAXONOMIC DESCRIPIIONS

TAXONOMIC KEYS

\section{UNDERWATER OPERATIONS-UN}

BOTTOM MOVIES

BOTTOM PHOTOGRAPHS

OBSERVATIONS BY OIVERS

OBSERVATIOR.S oY TV

OBSERVATIOT.S FrJ́M SIJRFACE SHIP

- Hegles affininies

iage vasietr studies

frical oig-2 surican

REMOTELY COPITROUIFO MAPHIPULATORS

UNOERWATER MOJIFS

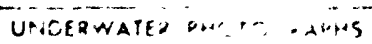

Uiveranato

|




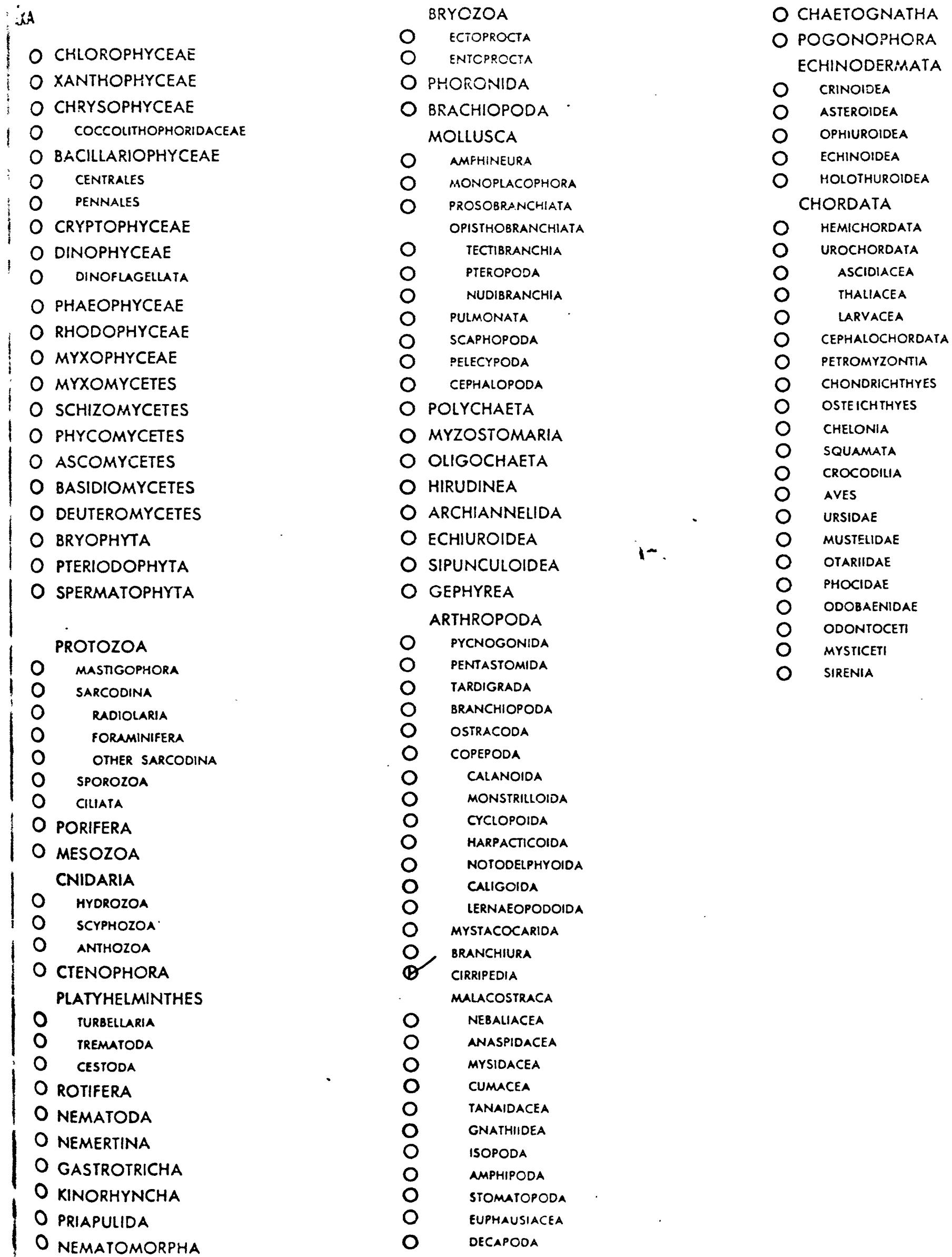

O acanthocephala 
ADOITIONAL TAXA

COTRYA

grCA

MMALUS

EACLITA 


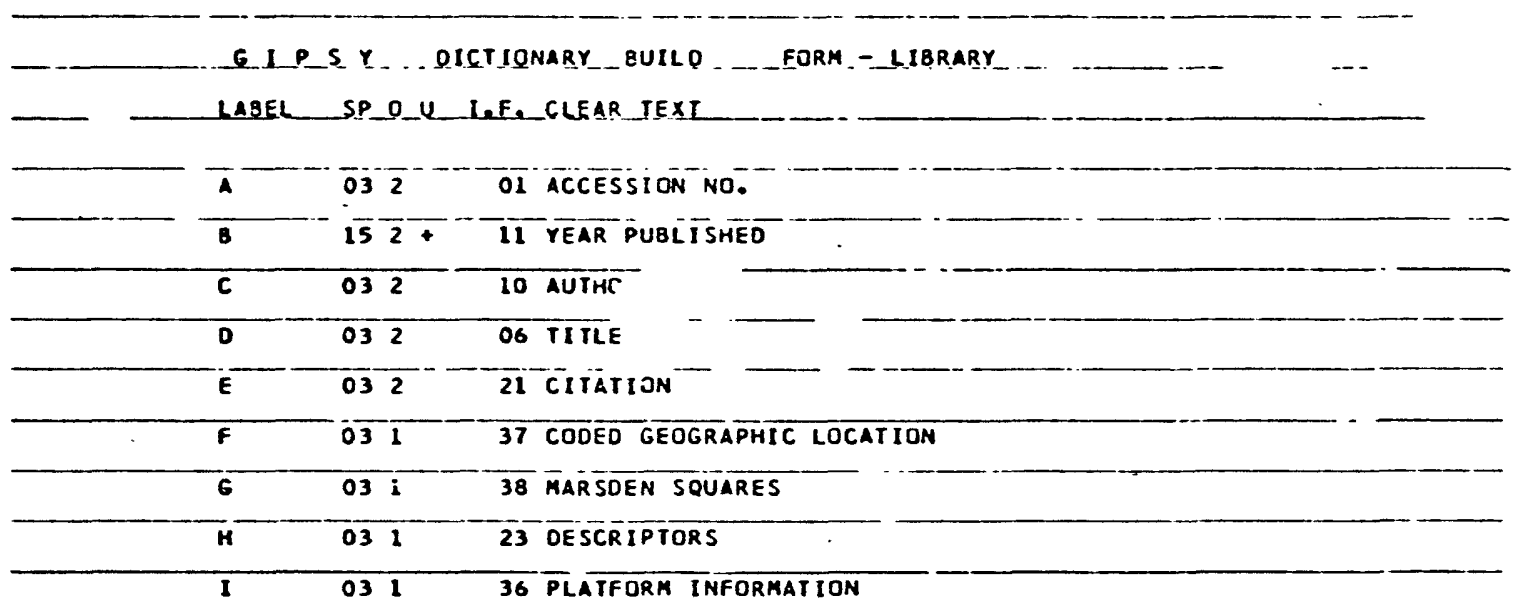

in.

Figure 9. -- GIPSY dictionary for the NODC Biological

Information Retrieval system. 


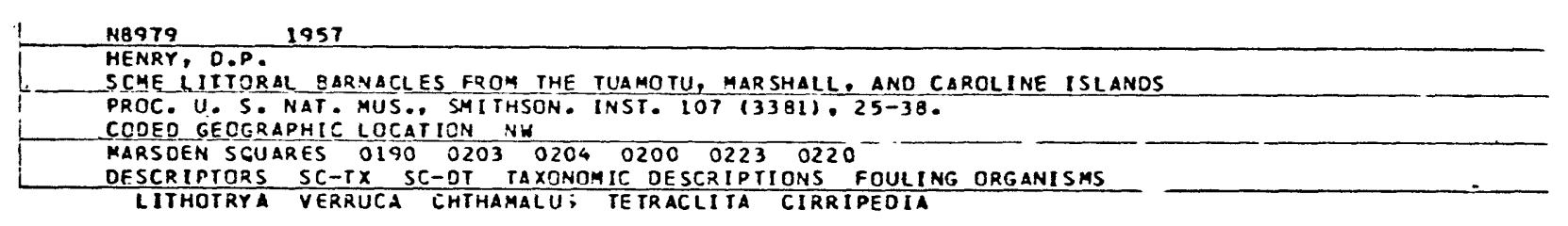

im.

Eigure 10. - GIPSY record from the NODC Biological Information
Retrieval system. 
NATURAL RESOURCES

APPLICATIONS

in. 


\section{Oil and Gas Field study}

The Cil and Gas Field study involves the compilation of a machine-retrievable data base of information on $U$. $S$. oil and gas fields by the oil Information Center, University - of Oklahoma Research Institute under a contract with the Department of the Interior (office of Oil and Gas, 1971). The study, which originated in the office of Oil and Gas, is supported by the Bureau of Mines, the Geological survey, the oil Import Administration, the Federal Power Commission, and the office of Emergency preparedness. Six files related to this study are described below. 


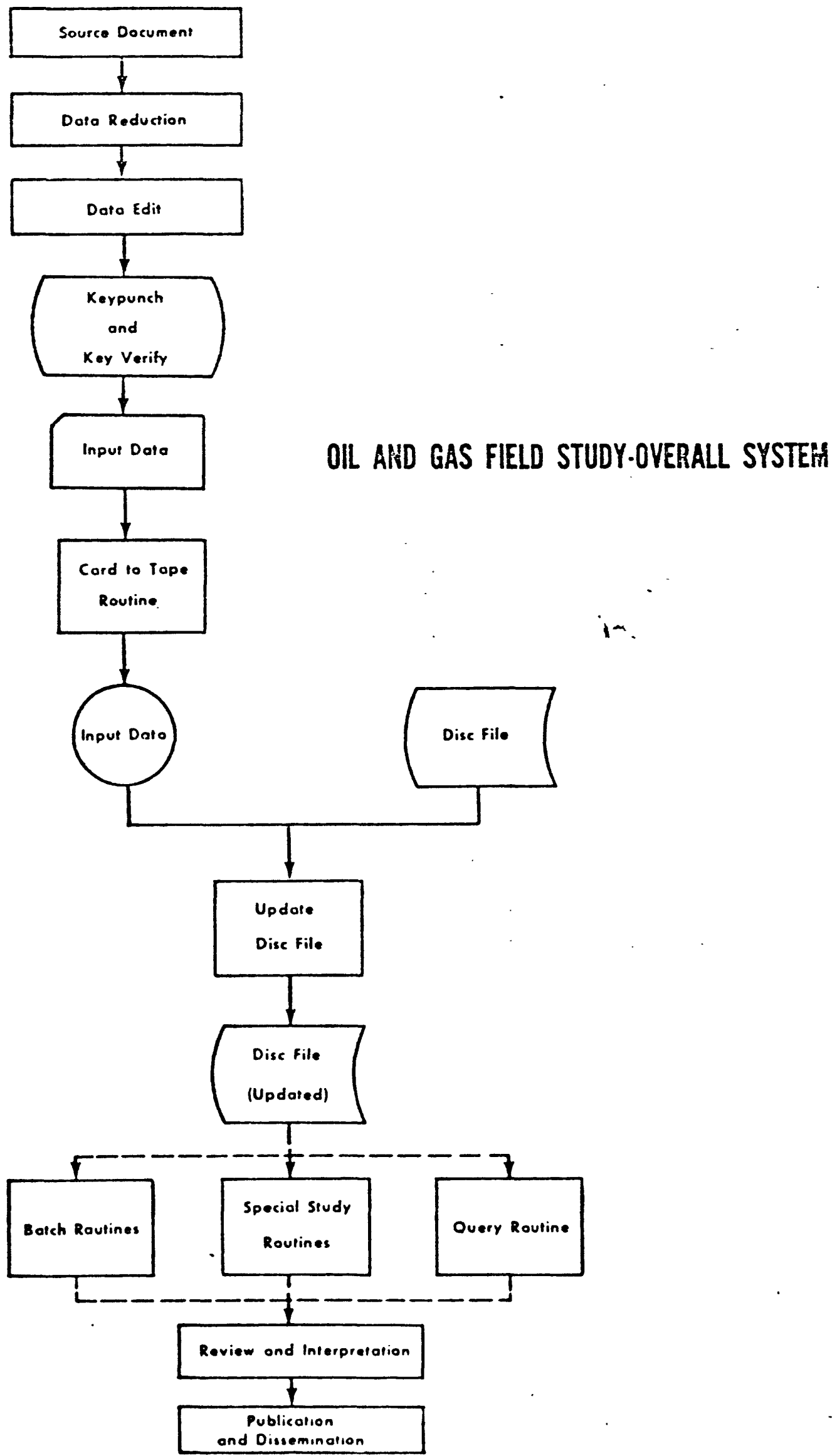

Pigure 1l. - Flow chart of overall system for the oil and gas Field study. 

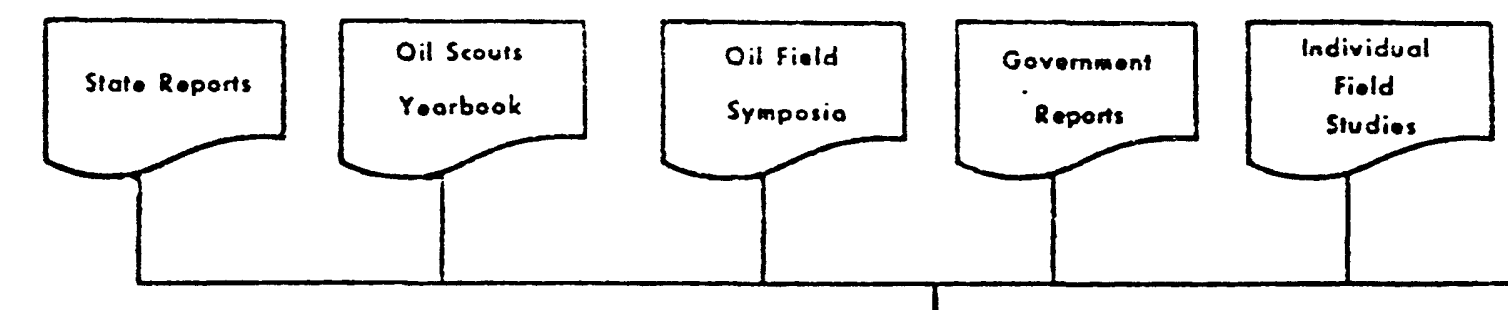

\section{Other Special}

Publications

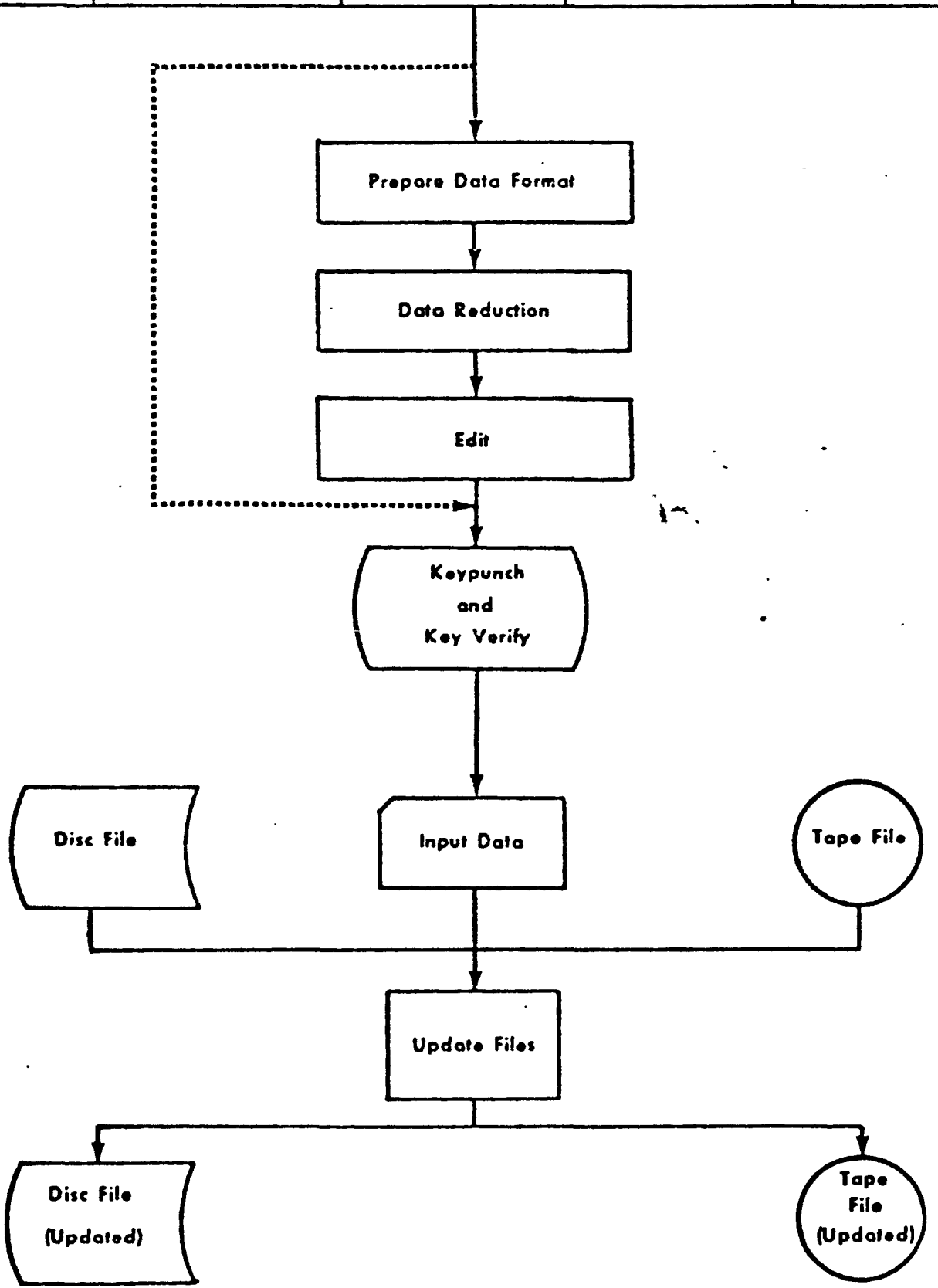

Pigure 12. -- OIL AND GAS FIELD STUDY - INPUT PROCESS 
Title: 0 il and Gas Field File

Sponsor: U. S. Department of the Interior Office of $\mathrm{Cil}$ and Gas

Washington, D. C. 20240

Contact: Richard F. Meyer, (202) 343-5093

Status of application: Pilot file

Objectives: To provide a file of published information on oil and gas pools in the United states in order to relate production to geographic and geologic areas, and to fluid analyses. The file will also provide a means of estimating recoverable reserves.

Source documents: Resource information is obtained from monthly or annual field production reports published by oil and gas producing states, symposium volumes prepared by local geological societies, journal articles and files of the Bureau of Mines and the Federal Power Commission.

File organization: Each record contains up to 605 data elements describing the location of the pool, pool classification, geologic occurrence, producing status, discovery well, wells and acreage, physical reservoir data, gas pressure and gas-oil ratios, annual and cumulative production, and reserves. Pools are identified by name and a Federal Power Commission field code. Geographic coordinates may be added at a later date.

Users: At present the major users are agencies sponsoring the study: The Office of Oil and Gas, Bureau of Mines, Geological Survey, Bureau of Land Management, and oil Import Administration of the Department of Interior; the Federal Power Commission; and the office of Emergency Preparedness. These agencies utilize the file for research and planning purposes.

Size of file: Approximately 37,000 records at present. The maximum size of the file will be about 60,000 records. 
FORM - OOGEOI

A IDENTIFICATION
AI CONTINENT $\leq$ NORTH AMERICA $>C O A T$

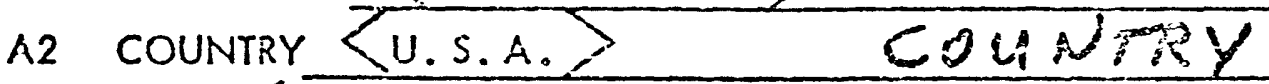
A3 STATES $S P A+2$
A4 COUNTYS COUATY
A5 FIELDS FiE E
A5A FIELD CODE NUMBER (FROM FPC CODE BOOK)S FLDCODE
A5B UNIQUEID NUMBER UNIOID
A6 POOL $P$ POL
A7 SOURCE DOCUMENT (RECORD NAME, VOLUME, NUMBER AND DATE)
DoCUM

B POOL DATA

B1 REgUlATORY district (TEXAS RRC DIST.) $R E G D i 5 i$

B2 PRODUCING FORMATION NAME

PRODFOR

B3 GEOLOGIC AGE OF PRODUCING FORMATION (FROM DICTIONARY OF STRATIGRAPHIC NAMES)

B3A ERAS ERA
B3B SYSTEMS S SYST
B3C SERIES SSERIES

B4 DESIGNATION OF FIELD \& POOL BY STATE REGULATORY AGENCY (CIRCLE PROPER CODES)

BAA OIL OIL

B4B CONDENSATE CONDEN

B4D ALLOCATED OR EXEMPT ALOEX

BHC GAS GAS

B4E NON-ALLOCATED OR NON-EXEMPT

BLF GAS STORAGE GASTOR $C_{P}$

B5 OFFSHORE (CIRCLE IF POOL IS OFFSHORE) OFFSHR
B5A LOUISIANALLAOFE
B5B TEXAS $T E X O F E$
B5D
B5C CALIFORNIASEALOFE $B 5 E$

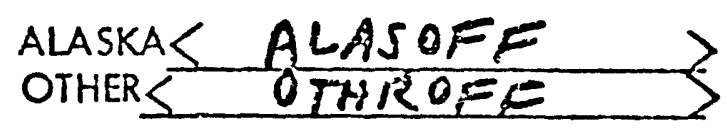

C POOL DATA (GENERAL INFORMATION)

CI NUMEER OF POLSIN FIELDS >

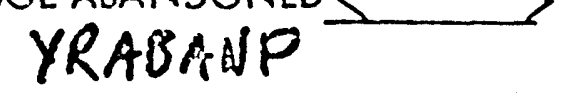
YRDISCP

(Revised $12 / 70)$

Pigure 13. - Input document for the 011 and Gas Field 


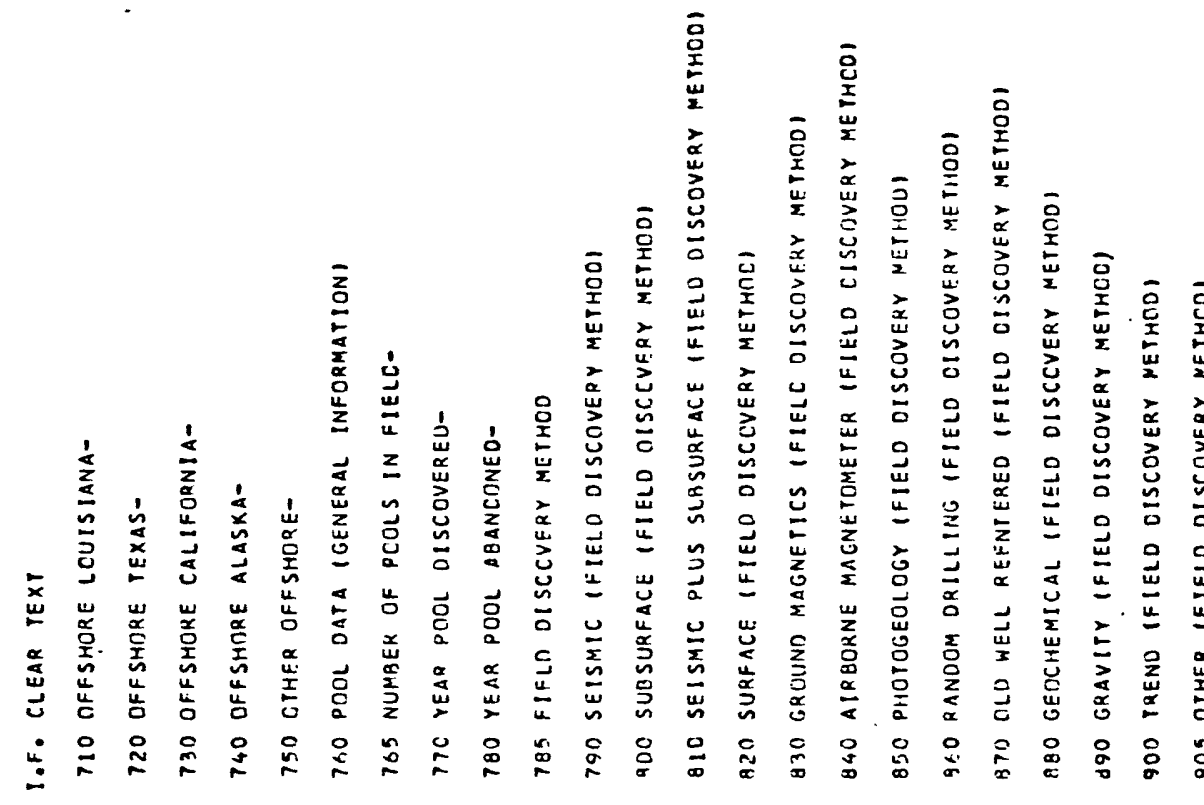

0
0
-1
$4-1$
0
0
0
0
-1
01
0
0
0
0
0
0
0

คิ

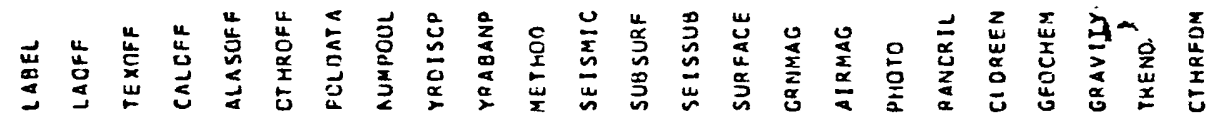

$\underset{-1}{-1}$

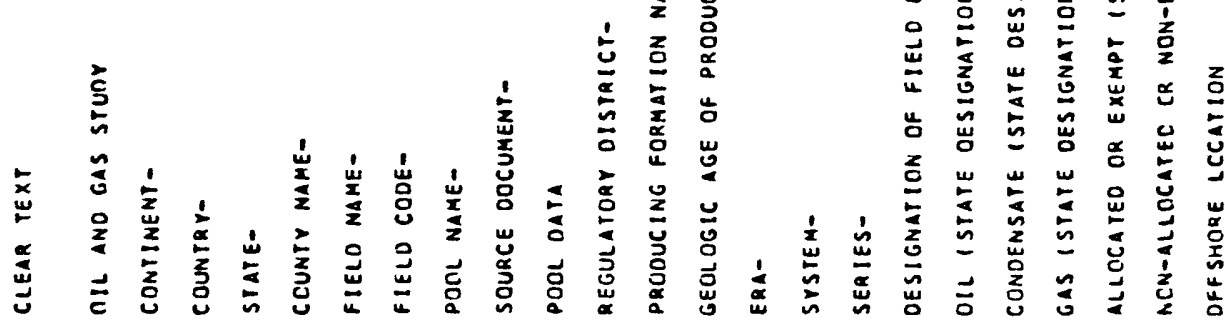

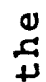

ro

$\vdots$ ○

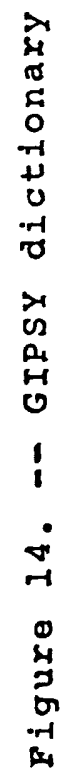

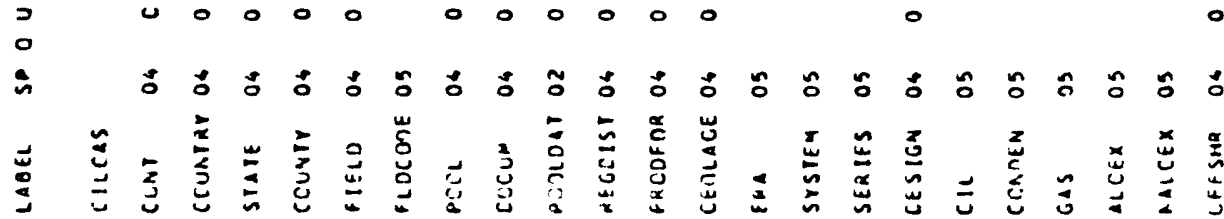



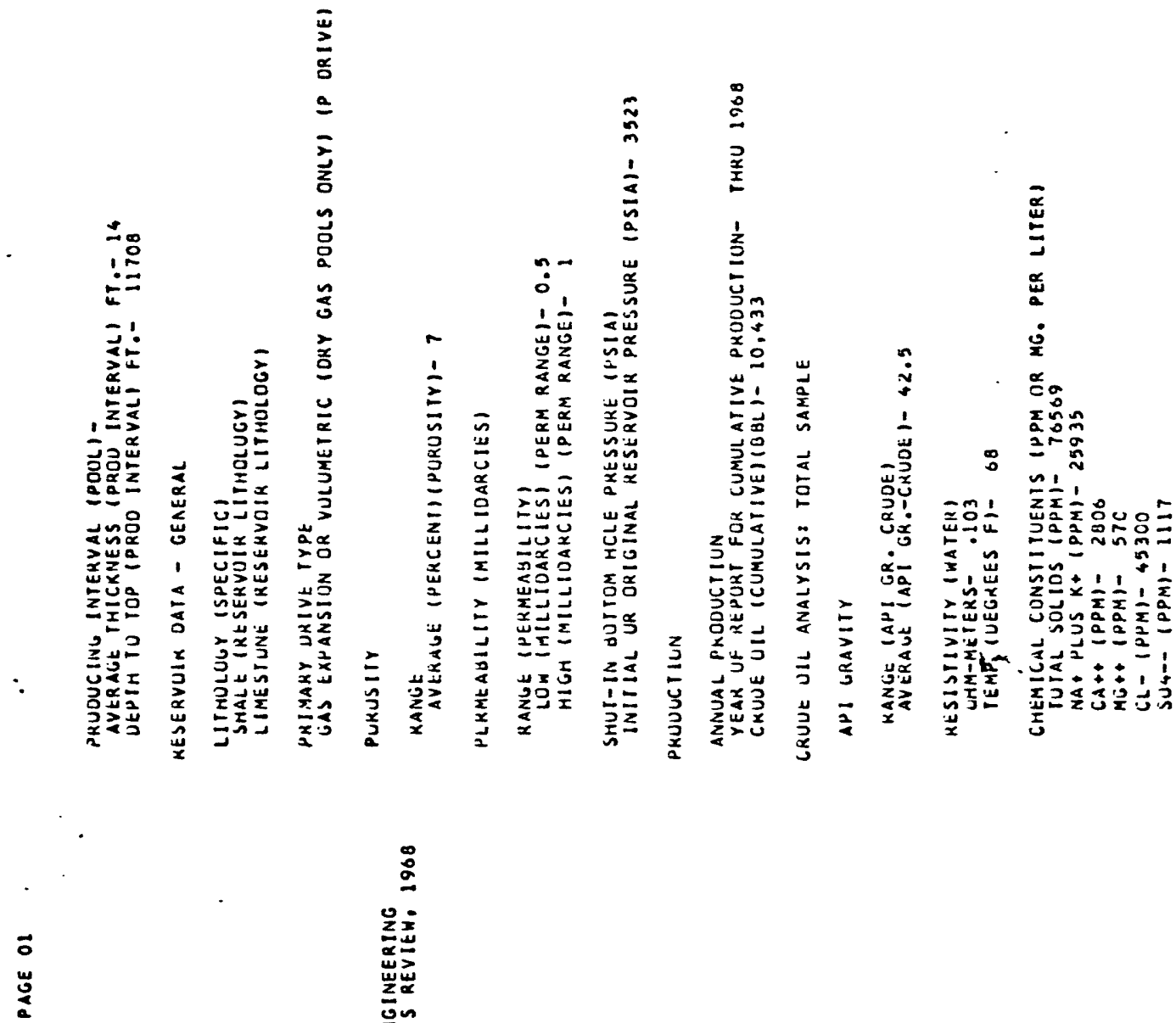

$\stackrel{\circ}{\circ}$

줄

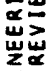

ㅎำ

ปู

=음

这

臸政

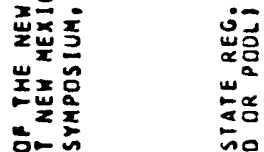

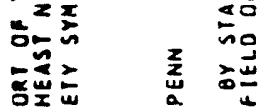

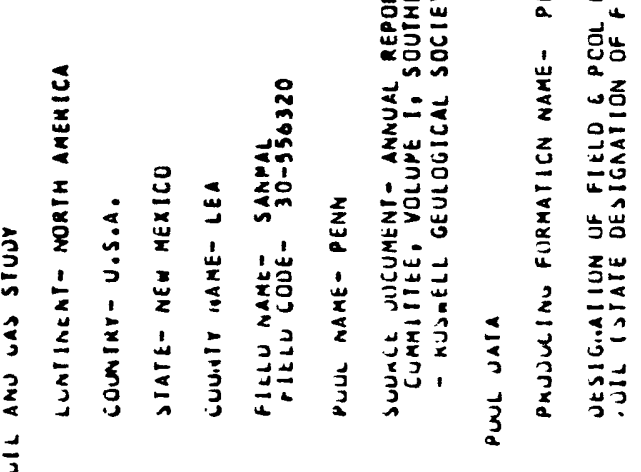
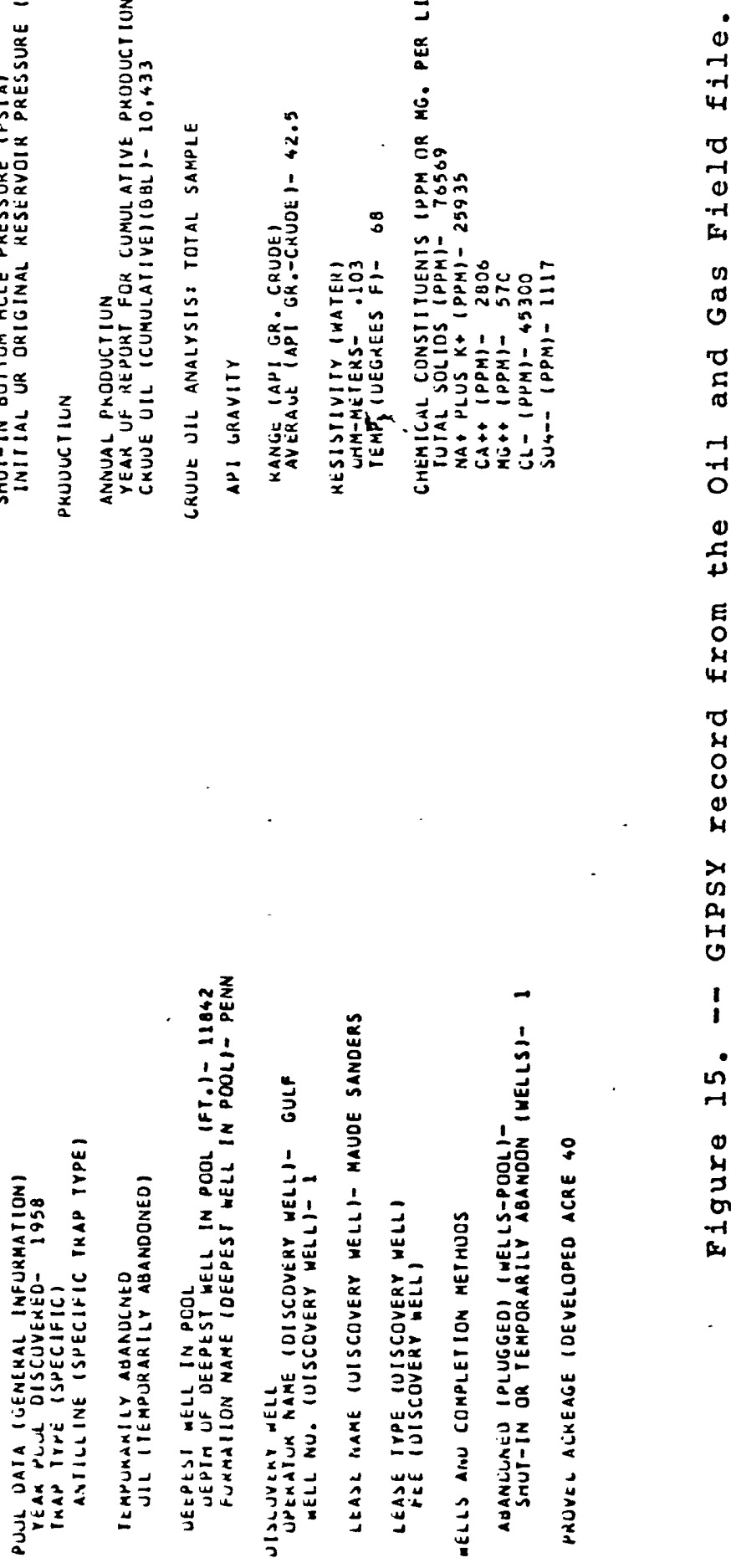
Title: Federal power Commission -. South Louisiana Area File

Sponsor: U. S. Department of the Interior office of oil and Gas

Washington, D. C. 20240

Contact: Richard F. Meyer, (202) 343-5093

Status of application: operational File

Objectives: To provide a file of data gathered during price rate hearings on gas fields in the FPC south Louisiana Area. The data will be used primarily for research and planning.

Source Documents: Records presented during the FPC South Louisiana Area rate hearings.

in.

File organization: Each record may contain up to 355 data elements. The data are similar to that contained in the oil and Gas Field File.

Users: Primarily the U. S. Geological survey and the Federal Power Commission.

Size of File: The file contains 5,221 records and is complete. 
Title: Natural Gas Analyses

Sponsor: U. S. Department of the Interior Office of $D i l$ and Gas

Washington, D. C. 20240

Contact: Richard F. Meyer, (202) 343-5093

Status of Apolication: Operational file

Objectives: To provide a file of natural gas analyses collected by the Bureau of Mines, principally under its helium program. The analyses will be used for research and planning purposes.

Source documents: Analyses were provided by the Bureau of Mines, Amarillo, Texas on magnetic tape. The tape data was converted to the GIPSY system using an auxiliary program.

File organization: Each record may contain up to 35 data elements which include: identification of the analysis, location of the sample, wellhead pressure, heating valve, specific gravity, and gaseous constituents (mol percent). provision is made for remarks pertaining to the analysis.

Users: See Oil and Gas Field File

Size of file: At present the file contains 4500 records. It will be updated periodically. 
Title: Crude Oil Analyses

Sponsor: U. S. Department of the Interior office of $O i l$ and Gas

washington, D. C. 20240

Contact: Richard F. Meyer, (202) 343-5093

Status of application: operational file

objectives: To provide a file of crude oil analyses performed by the U. S. Bureau of Mines since 1921. These analyses will be used for research and planning purposes.

Source documents: Analyses were provided by the U. S. Bureau of Mines, Bartlesville, oklahoma on punched cards. The card data were converted to the GIPSirsystem using an auxiliary program..

File organization: Each record may contain up to 124 data elements which include: identification of the analysis, location of the sample, specific gravity, API gravity, sulphur content, nitrogen content, asphalt content, isotope ratios, carbon residue, viscosity, residuum (percent of crude, specific gravity, and volume percent), volume percent and molecular weight of each petroleum fraction, metals present.in oil, and related data.

Users: See oil and Gas Field File

Size of file: At present this file contains 6,059 records. The file will be updated periodically. 
Title: Oil Field Brine Analyses

Sponsor: U. S. Department of the Interior office of Oil and Gas

Washington, D. C. 20240

Contact: Richard F. Meyer, (202) 343-5093

Status of Apolication: Operational file

objectives: To provide a file of oil field brine analyses prepared by the Bureau of Mines. The information will be used to follow a number of lines of research related to oil production.

Source documents: Analyses were provided îy the U. S. Bureau of Mines, Bartlesville, Oklahoma on magnetic tape. The tape data was converted to the GIPSY system using an auxiliary program.

File organization: Each record may contain up to 66 data elements which include: identification of the analysis, location of the sample, analysis (agency), pH, specific gravity, chemical constituents (mg./liter), organic acids, and a section for other chemical data and notes.

\section{Users: See Oil and Gas Field File}

Size of file: At present the file contains 2700 records. It will be updated periodically. 
Title: Committee on Drilling Statistics Well Data File

Sponsor: U. S. Department of the Interior

office of Oil and Gas

Washington, D. C. 20240

Contact: Richard F. Meyers (202) 343-5093

Status of application: Dlanned file.

Objectives: To provide statistical analyses of exploratory wells drilled in the United states since 1953 and of development wells drilled since 1964. Of particular interest will be an analysis of factors affecting success ratios of different classes of wells drilled.

$$
\text { in. }
$$

Source documents: Magnetic tapes of data gethered by the Committee on Driling Statistics of the American Association of Petroleum Geologists are available for exploratory wells drilled since 1964 and exploratory and development wells since 1966. Data sheets are available for exploratory wells drilled between 1953 and 1964 .

Users: See Oil and Gas Field File.

Size of file: The file is planned to contain approximately 75,000 records. 


\section{Title: Computerized Resource Information Bank (CRIB)}

Sponsor: U. S. Geological survey

Geologic Division, Branch of Mineral Resources

Washington, D. C. 20242

Contact: James A. Calkins, (202) 282-7268

Status of application: Pilot ilile

objectives: To provide archival storage for mineral resource data collected as part of the Survey's Mineral Resources Inventory Program. The File will provide basic statistics on the past production and future potential of over 200 commodities in the United States as well as information on their geographic distribution, geologic setting, and mineral assemblages.

Source documents: Resource information is acquired from existing mancial card files, regional economic geologists and commodity specialists engaged in field work as part of mapping programs, and literature searches.

File orqanization: Each record may contain up to 180 data elements. Record identification is provided by country, state, county, district (area), and name of the deposit.

- Latitude and longitude, UTM coordinates, and altitude describe the mineral deposit location. Each commodity present at the site is Iisted together with its production significance, ore production (weight, grade, and year produced), commodity production, and known or estimated reserves. The record also describes the geologic setting of the deposit, related mineral assemblages, and descriptive notes. References to the source of information are cited at the end of the record.

Users: Commodity specialists, economic geologists, and field project leaders of the Survey's Geologic Division will evaluate availability of specific commodities as the need arises. Other commodities will be routinely monitored.

Size of file: The file contains approximately 25 records for use in developing procedures for building an operational file. 
Problems: Data on the amount, units of measurement, accuracy, and grade must be repeated for the production, potential reserves, and potential resources of each commodity present at the site. The presentation of this material is handled by assigning separate sets of labels to each class, i.e., production, potential reserves, and potential resources. A maximum of 6 commodities in each class is assumed. While this presentation is suitable for a display of the entire record, retrieval of data on specific commodities is cumbersome. The presentation can be improved by presenting the data in fixed fieldfixed length format within a GIPSY label. 


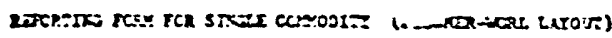

compdis.mpores:tex

noe (coredity)

D Simflicarcas aze rijor

Lo riner

160 oceurredes 170 prenelel

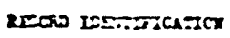

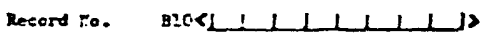

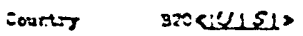

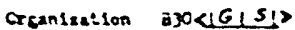

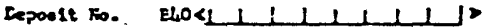

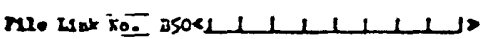

$290<$ (associaled comodilies)

$$
\text { Tarostraral }
$$

WWE 10 ICA:ICR

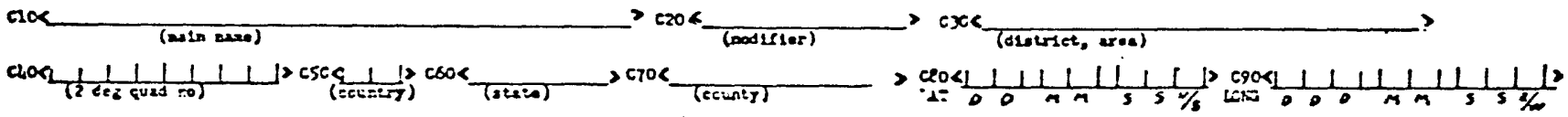

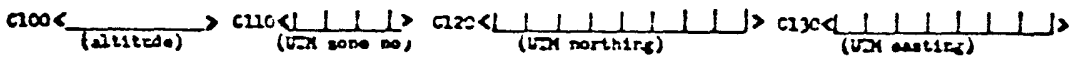

Cas medestix, xis

D10 Ko madac: 1 on

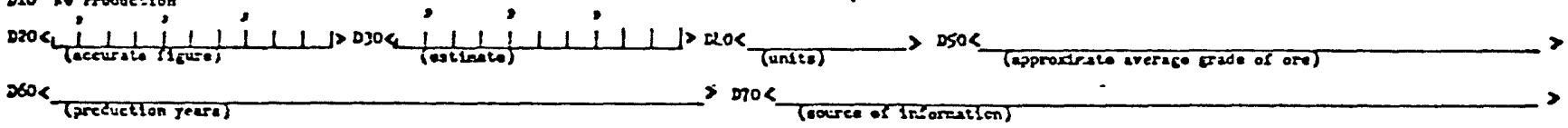

$1-$

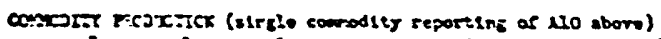

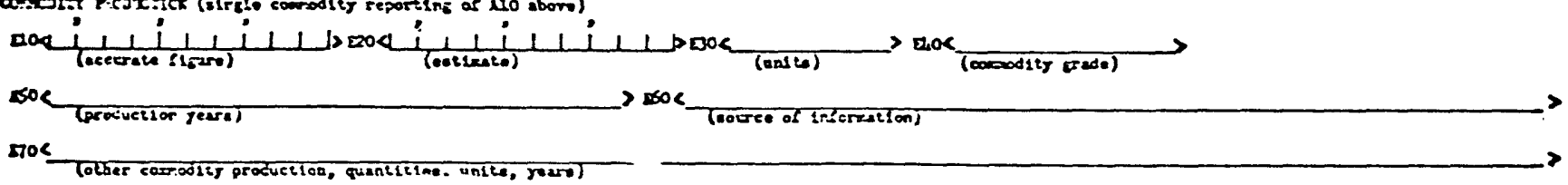




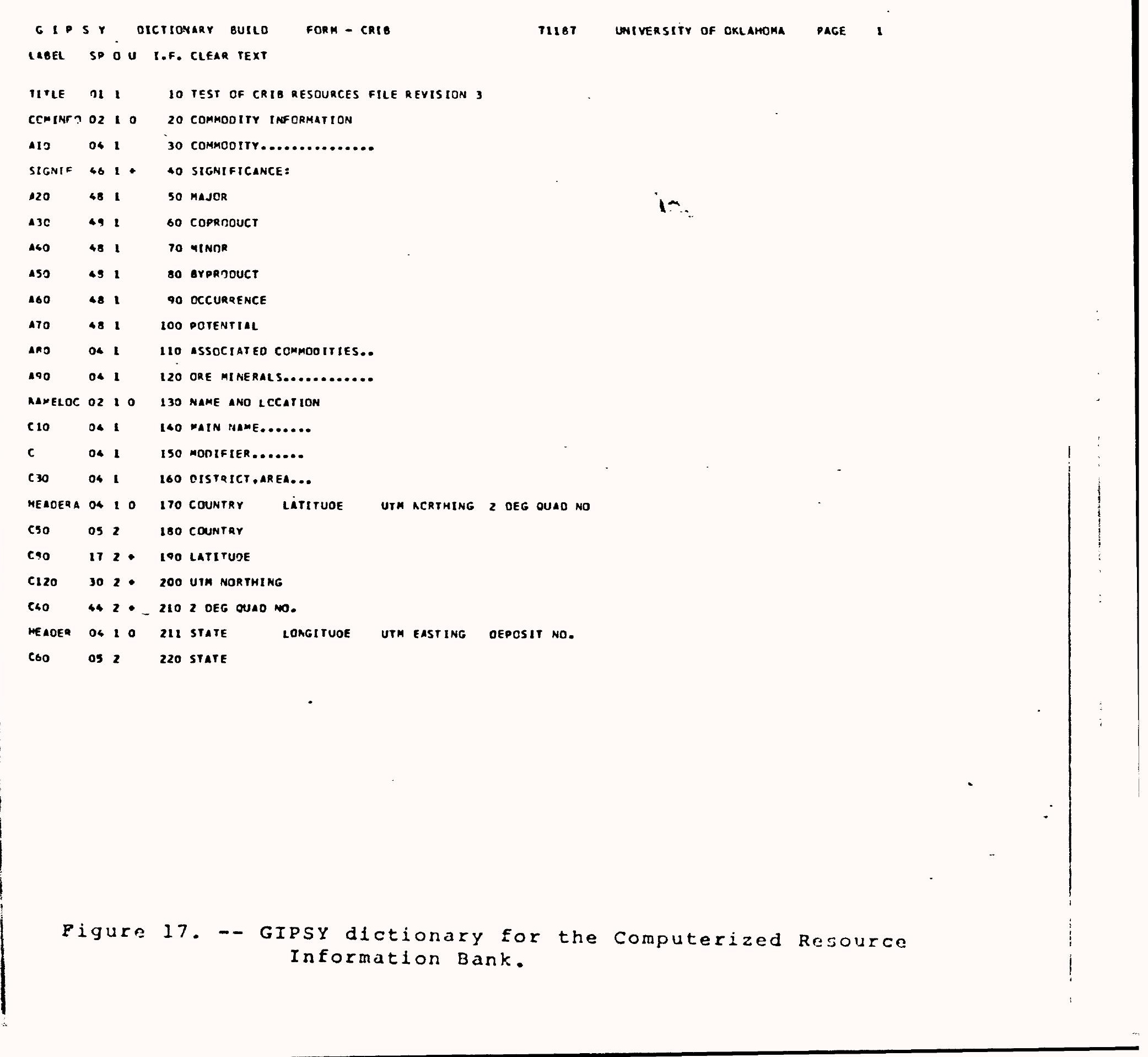




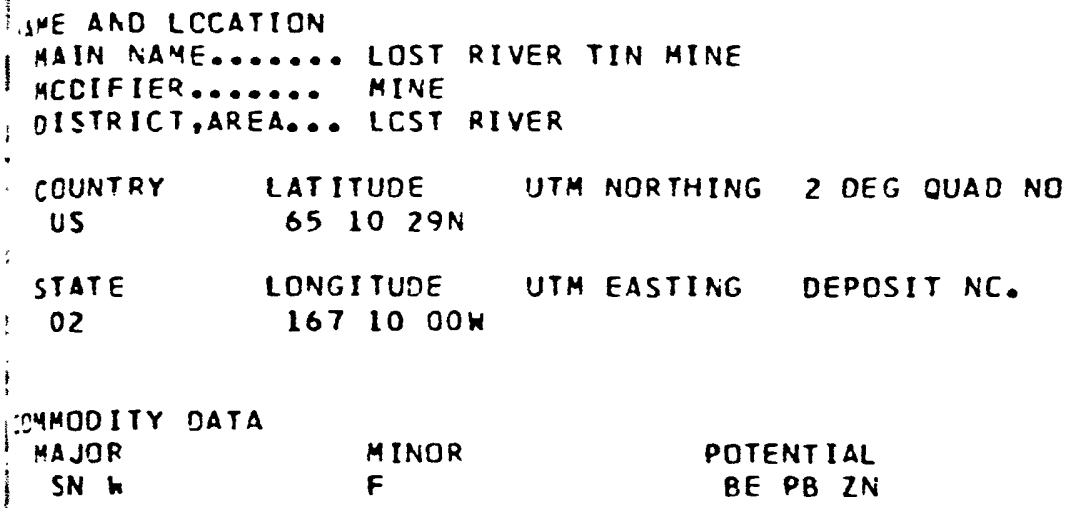


Title: Microprobe Data System

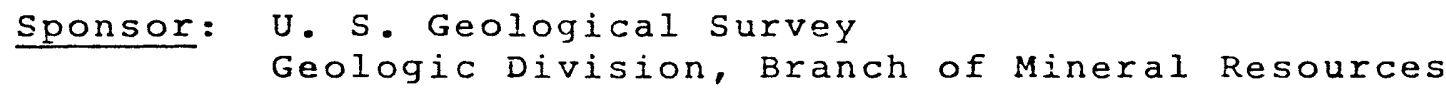
Washington, D. C. 20242

Contact: R. Barry Finkelman, (202 282-7341)

Status of application: Operational file (inactive)

Objectives: To organize and tabulate large numbers of microprobe analyses and produce graphical reports by specific elements. $\frac{\text { Source documents }}{\text { cards }}=$ Laboratory analytical sheets and punch

File oraanization: Morphological and optical data are stored together with microprobe analyses.

Users: Micromineralogy Study Group

Problems: Data from microprobe analyses were placed on cards in a fixed-length, fixed-field format and then converted to GIPSY format. Major changes in the punch card format at a later date required that the conversion program to GIPSY format be rewritten. This has not been done to date. 
Title: River Basin Characteristics

Sponsor: U. S. Geological survey

Water Resources Division

Systems Laboratory Group

washington, D. C. 20242

Contact: David W. Moody, (202) 343-3626

Status of application: Pilot file

Objectives: To provide hydrologists with a convenient means of storing and retrieving physiographic and meteorological parameters controlling the streamflow characteristics of river basins. During a recent review of the Geological Survey's stream gaging network, physiographic and meteorological parameters were measured and various streamflow statistics were computed. Regression models were then developed which related the streamflow characteristics to the river basin characteristics for the river basin or hydrologic region. This file will facilitate further studies of the interrelationships between river basin characteristics.

Source documents: Punch card files and state reports.

File organization: In its present form each record may contain up to 105 data elements which include the USGS station number, station name, physiographic parameters, meteorological parameters, and streamflow parameters. other data elements can be easily added to the file as the need arises.

Users: USGS hydrologists, other Federal agencies and state cooperators.

Size of file: The pilot file contains information on stations located in the state of Kansas. 
IMTERNAL EXTERNAL SPACING DPTION USASI CLEAR TEXT

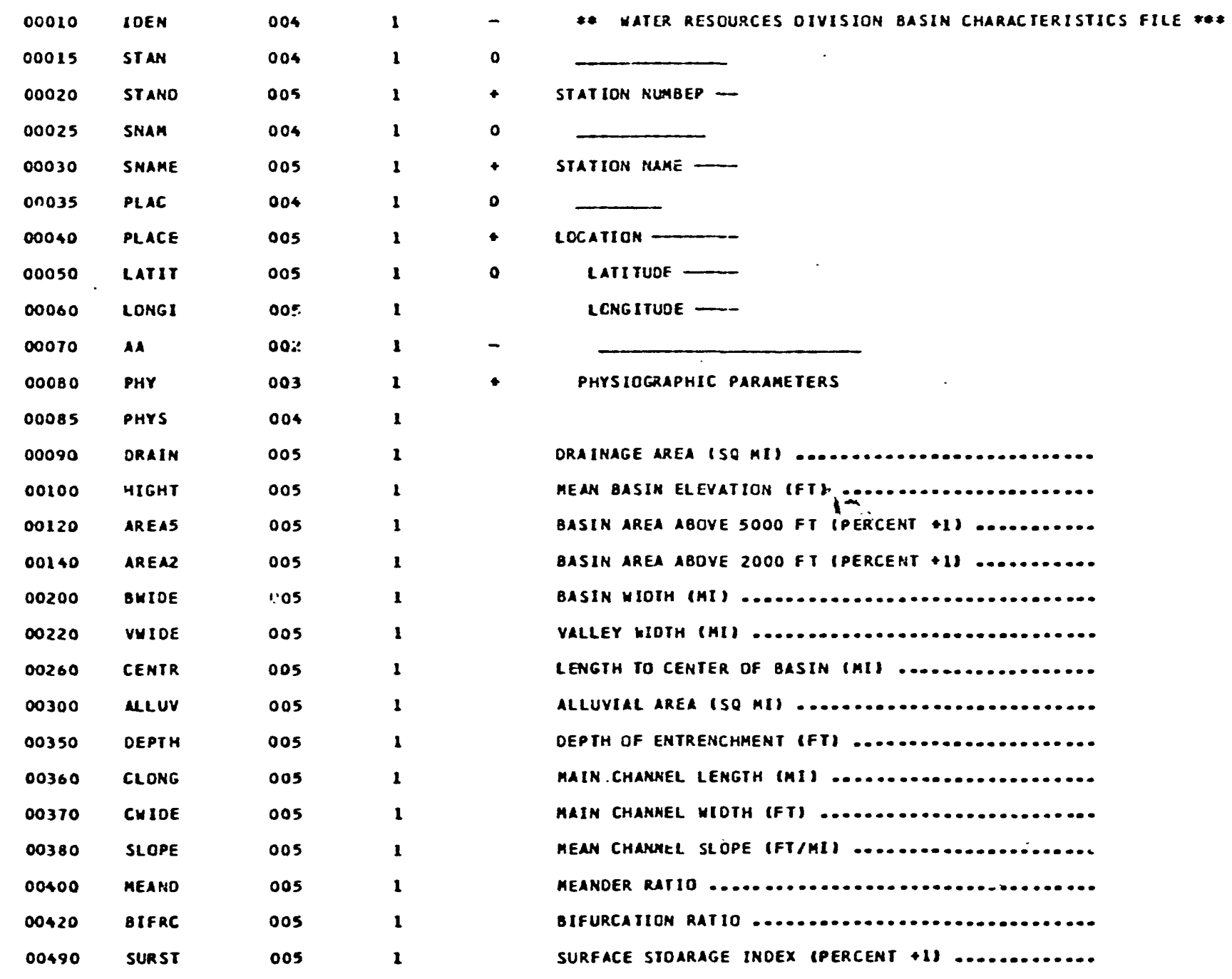

Figure 19. -- GIPSY dictionary for the River Basin characteristics file. 
STOIICH NUABER-- 068680
SIATION NAME_-- SALINE R VR WILSON, KANS.

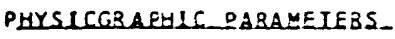

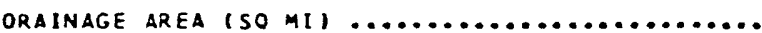
MEAN BASIN ELEVATION IFT) ..................

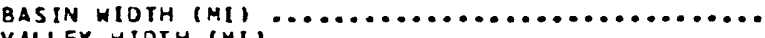

VALLEY WIDTH (MI) ........................

LENGTH TO CENTER OF $3 A S I N$ IMII $\ldots \ldots \ldots \ldots \ldots \ldots \ldots \ldots$

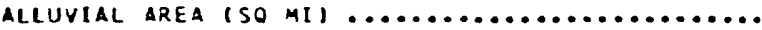

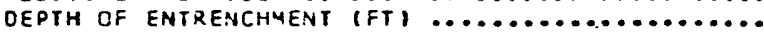

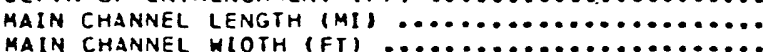

MAIN CHANNEL WLOTH IFT) ....................

MEAN CHANNEL SLOPE (FTIMI) ..................

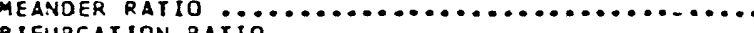

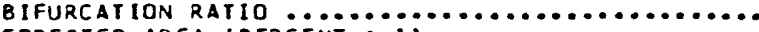

FORESTED AREA (PERCENT + 1 ) $\ldots . .00$.

MEDIAN GRAIN SILE OF BEO MATERIAL IMHI .........

MEIEOBOLOGLCAL PABAMEIEBS

AVE. MIN. JAN. DAILY AIR TEMPERATURE IOEG FI .... AVE. MAX. JUL. DAILY AIR TEMPERATURE IDEG FI $\ldots$

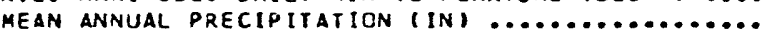

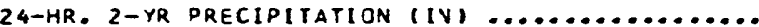
24-HR, 1OO-YR PRECIPITATIOV (IN) $\ldots \ldots \ldots \ldots \ldots \ldots \ldots$ MEAN ANNUAL SNOWFALL $(I N) \ldots \ldots \ldots \ldots \ldots \ldots \ldots \ldots \ldots . . \ldots \ldots$

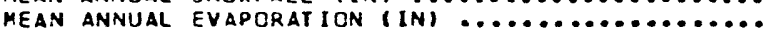
SOIL CONSERVATION SERVICE WSW INOEX $\ldots \ldots \ldots \ldots \ldots \ldots$

$1900.000 C$ 2280.0000 7.2500 123.0000 123.0500 0000 262.0000 60.0000 7.5200 1.5700 4.9500 1.1800 1.1800

.2500

18.0000

95.1000

21.9900 2.4800 5.9900 21.2700

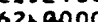
62.0000
3.0500

SIREAMELOH PABAMEIEBS

ANNUAL OISCHARGE STATISTICS

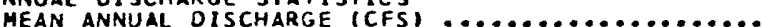
STANOARO DEVIATION OF ANNUAL MEAN OISCHARGES $\ldots$ SKEWNESS OF ANNUAL MEAN OISCHARGES $(+1.006) \ldots \ldots$ IST ORDER SER. CORREL. ANN. MEAN OISCH. $(+1.000 i$.

165.6000 148.7000 3.5770 1.1470

MONTHLY OISCHARGE STATISTICS

MEAN OCT. OIS MEAN NOV. DISCHARGE (CFS) ..................

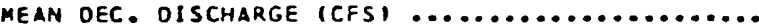

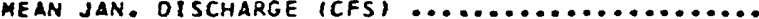

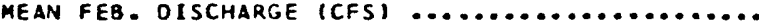

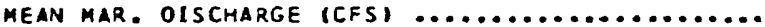

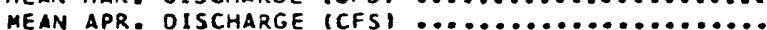
MEAN APR. DISCHARGE (CFS) $\ldots \ldots \ldots \ldots \ldots \ldots \ldots \ldots \ldots \ldots$ 
Title: WRD Biological Data File

Sponsor: U. S. Geological Survey

Water Resources Division, Systems Laboratory Group Washington, D. C. 20242

Contact: David W. Moody, (202) 343-3626

Status of application: Pilot file

Objectives: In addition to streamflow data and water quality data, WRD also collects biological data on streams, lakes, and reservoirs. While water quantity and quality information is routinely handled with ADP techniques, biological data are difficult to handle because of the great variety of aquatic organisms. A truly national system for biologic data would have to be able to handle thousands of codes for all the plants and animals commonly found. In one place, however, only a relatively few species would be needed - for example, 10 phyla and 60 species cover nearly all animals accounted in a study of a Maryland estuary. Therefore, it was desired to have a retrieval program which could be first applied at the local or regional level, and which would be.compatible upwards with an eventual national system. Another problem was the establishment of temporary names for unidentified organisms - for example." "Stalked yellow spheres" - until such time as the organism is identified. The purpose of this file was to demonstrate the application of GIPSY to the storage and retrieval of this type of information.

Source documents: Field notes and laboratory card file

Plle organization: Each record may contain 30 data elements or more depending upon the number of species of animals encountered in a sample. Information included station number, stream name, latitude and longitude, mile point on stream, crossection position, depth, type of sample (grab, dredge, or panel), other data available at site (chemical, physical, or environmental), description of bottom, sampling method, dates, panel analysis (wet volume, dry weight, ash weight, organic weight, etc.), number of phyla, genera, and species in sample, species list, and comments. 
In addition to the oper ended list of animals, a code was assigned to each species identified thus far in the project. For each species identified, the following information was provided in fixed-field, fixed-length format: density (weight per unit area of panel), percent coverage (percentage of panei covered by the particular species), maximum and minimum size ( $\mathrm{mm}$ ) of animals observed, descriptive notes. There were no limits placed on the length of the comments. since they occurred at the end of the fixed-length, fixed-field format.

Users: WRD research personnel.

Size of file: The pilot file contained 25 records.

$$
1 \cdots
$$




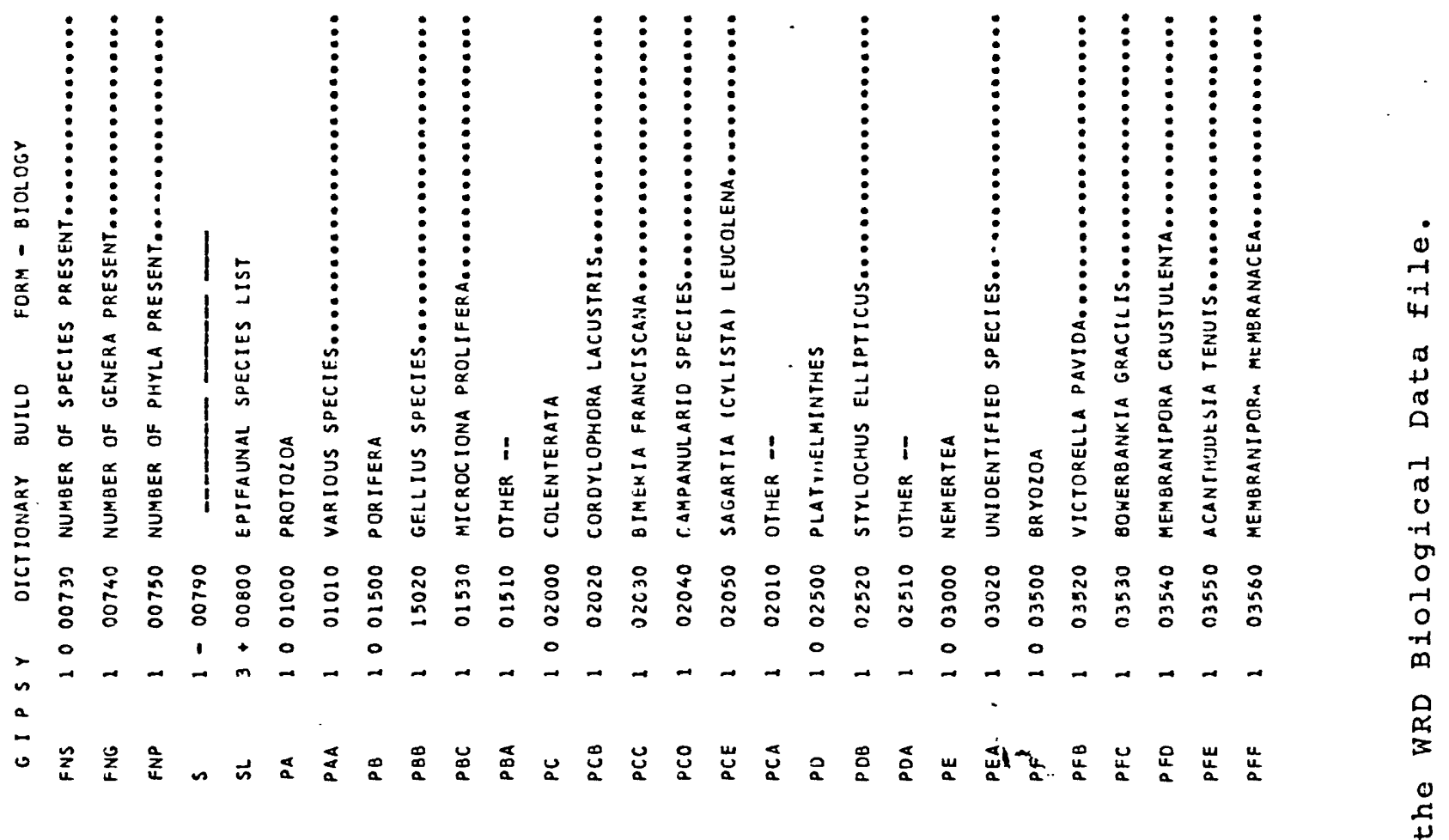

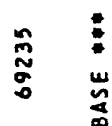

:

$\frac{\vec{s}}{\Delta}$

¿

음

is

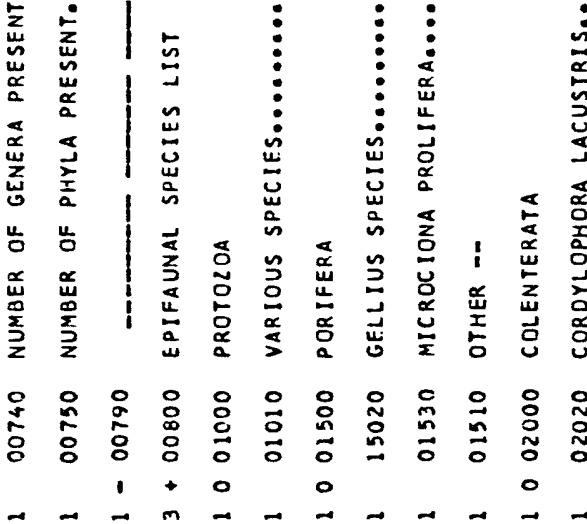

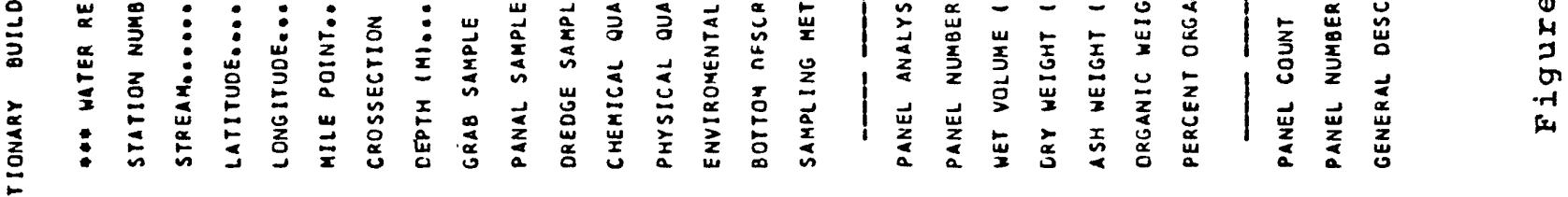
志

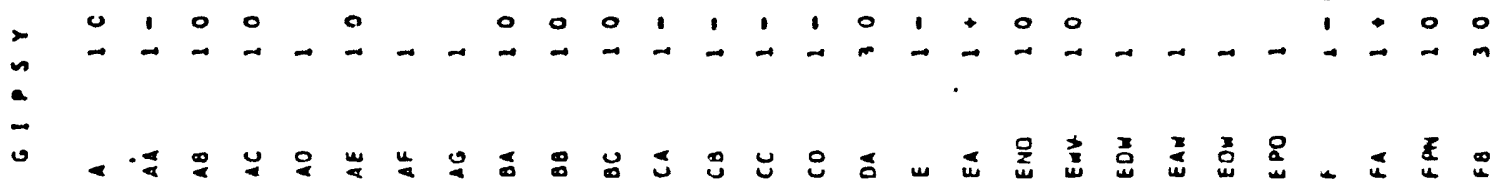


*** hater resources bidlogical data base ***

STATICN NUMBER......... 5 HALFMOON LANOING

STREAM............... NEWPORT R.. GA.

panel sample

SAMPLING METHOD

SUBMERGEO TEST PANEL O.1M ABOVE BOTTOM

DATE BEGIJN........... 690605

DURATION ............ 35

PANEL ANALYSIS

PANEL NUMBER -- G-29

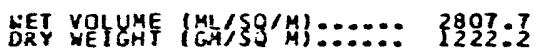

ASH WEIGHT (GN/SO MI...... 1098.3

ORGANIC WEIGHT (GM/SO M).. 123.8

PERCENT ORGANIC.

RAKES CEUNI

PANel NUMBER - G-30

GENERAL DESCRIPTION

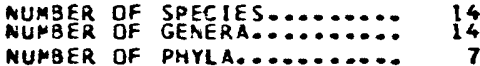

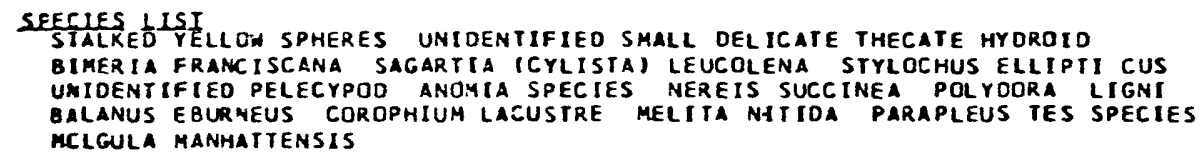

MCIGUL MANHATTENSIS

PRCTRZTOA

16.0

NOTED

COGENTERATÁRANCISCANA...............

Figure 22. -- GIPSY record from the WRD Biological Data file. 
Title: WRD Station File

Sponsor: U. S. Geological Survey

Water Resources Division

Washington, D. C. 20242

Contact: Robert A. Perry, (202) 343-2595

Status of application: Pilot file

Objectives: To provide a catalog of surface water, quality of water and ground water stations operated by the Geological survey for use in manaing the national hydrologic data collection program and in answering public inquiries.

Source documents: Magnetic tapes used by ithe office of Water Data Coordination to publish water data catalogs.

File organization: Records for surface water, quality of water, or ground water stations may contain up to 170 data elements which include station name and location llatitude and longitude, state, county, and river basin codel, type of site and station, frequency of data measurement, types of data collected, supplementary data available for the site, publication status and form of data storage, period of record, and office supplying information. The file organization is currently being reviewed prior to implementation.

Size of file: The pilot file contained information on 2,000 quality of water stations. The operational file will contain data on 18,000 surface water stations, 5,600 water quality stations, and 18,300 ground water stations. 


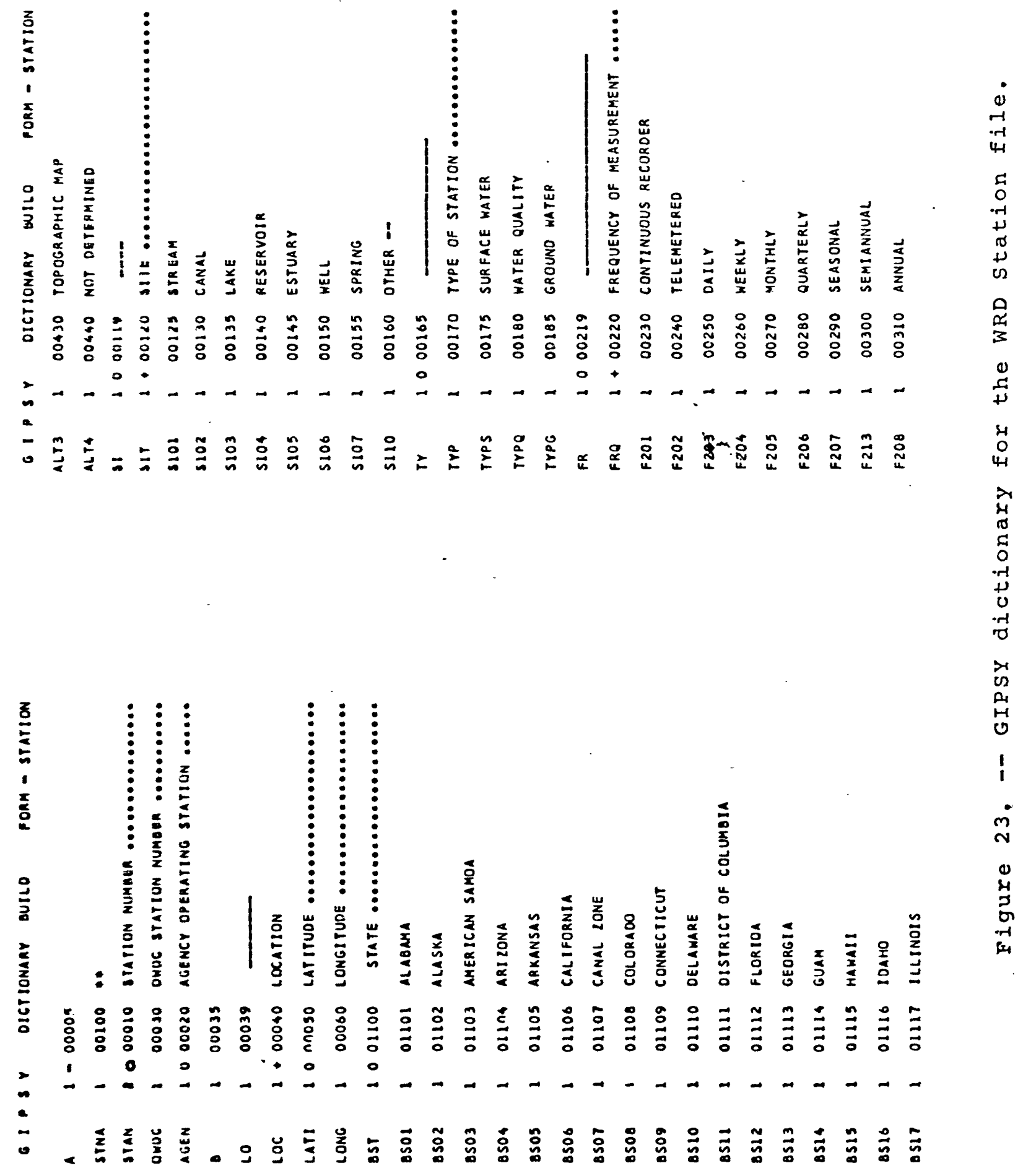


LIST OF ALABAYA OH STATIONS WHICH MEASURE SP. COND. AND OS PAGE OI

* conecuh r at brantlet ala

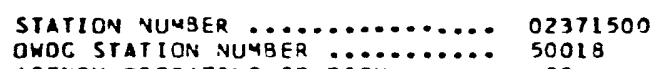

OGDE STATION NUMBER GDERTING STATION

LOCAIION

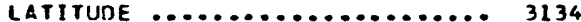

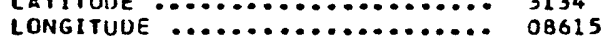

STATE ........................ 01

ALABAMA

COUNTY ..................... 041

CRENSHAW

THOC MAP NUMBER

12 I

STATUS

ACTIVE

SIIEE

101

TYPE-OE STAIJOY

WATER OUALITY

0

FREUUEACY_OF_ EEASUBEYENI_....... 201

CONTINUOUS RECORDER

IYPES_DE_DALA_COLLECIED.

$424 \quad 4 C 3$

* oualitr of hater data

TEMPERATURE ................. 1

SPECFIC CONDUCTANCE ............ 1

COLOR ....................

PH LAR ...

COMMON IONS

HARONESS $\ldots \ldots \ldots \ldots \ldots \ldots \ldots \ldots \ldots \ldots \ldots$

HARONESS $\ldots \ldots \ldots \ldots \ldots \ldots \ldots \ldots \ldots \ldots \ldots$
DTHER - .

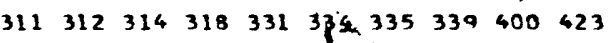

SUPIEYEAIARY_DAIA_EDB_SIIE

- surface hater Data

SURFACE WATER STATION

WATER STAGE OR LEVEL

WATER DISCHARGE

DRAINAGE AREA

PUBL_ICAILON_SIAIUS_AN2 SIORAGE_OE_DAIA_.. 901903

PERIODIC REPORT (5-YEAR COMP.)

Figure 24. - GIPSY record from the WRD Station file. 
Title: Massachusetts Gazetteer

Sponsor: U. S. Geological survey

Topographic Division, Office of Geographic Names

Washington, D. C. 20242

Contact: Samuel Stulberg, (202) 343-2276

Status of application: Pilot file

Objectives: To store information on geographic names and their related features for the United States, its territories and possessions. This file is to be used for names research, preparation of state gazetteer, answering inquiries and possibly to provide information for direct placement on maps.

Source documents: Punch card files in the office of Geographic Names, maps, and field research reports

File organization: Each record may contain up to 16 major data elements. These include the complete place name, the appellative or generic element, language information, name classification, date of name origin, relief of area, data of Board on Geographic Names decision for the name, kind of feature name applies to, state, county, map numbers, geographic coordinates (latitude and longitude), population, linear and areal dimensions of feature, elevation (feet above sea level), river basin code, sectiontownship-range location, description of feature, variant names applied to the feature, and history of the name including folk etymologies.

Users: Divisions of the USGS including the office of Geographic Names and the Map Information office.

Size of file: The present pilot file contains 5,000 names. The dictionary contains 418 labels. 


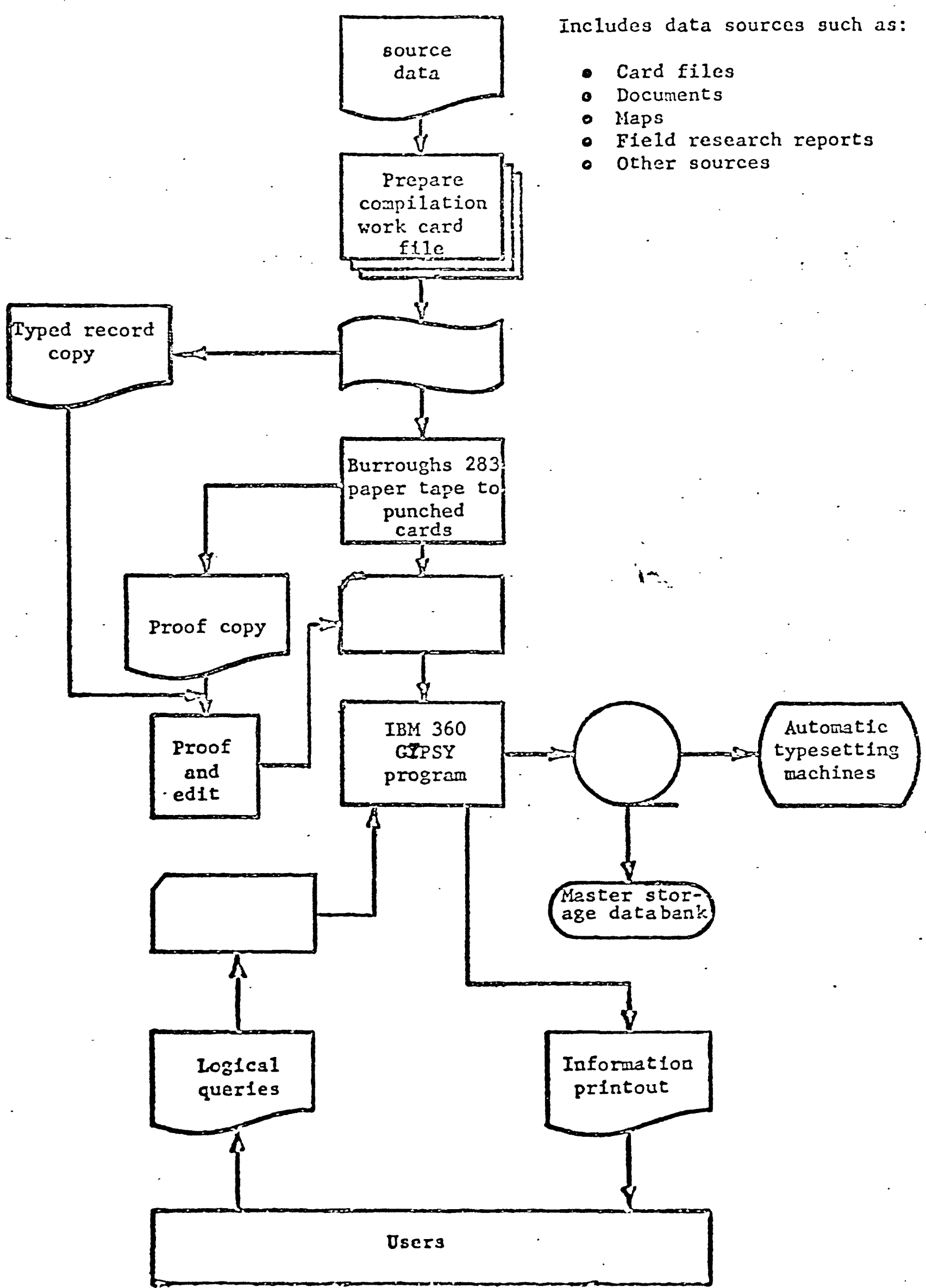

Pigure 25. -- Cosputer-based place-nace publication systea. 


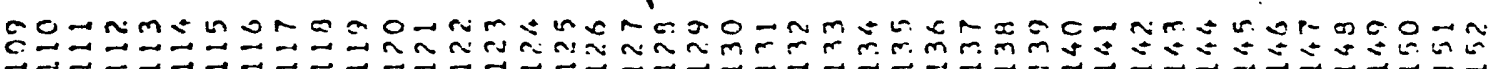

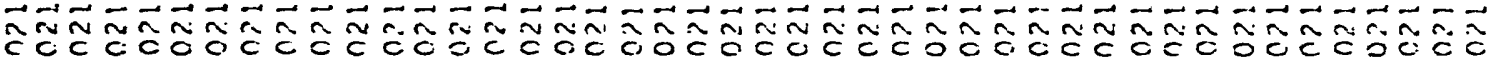

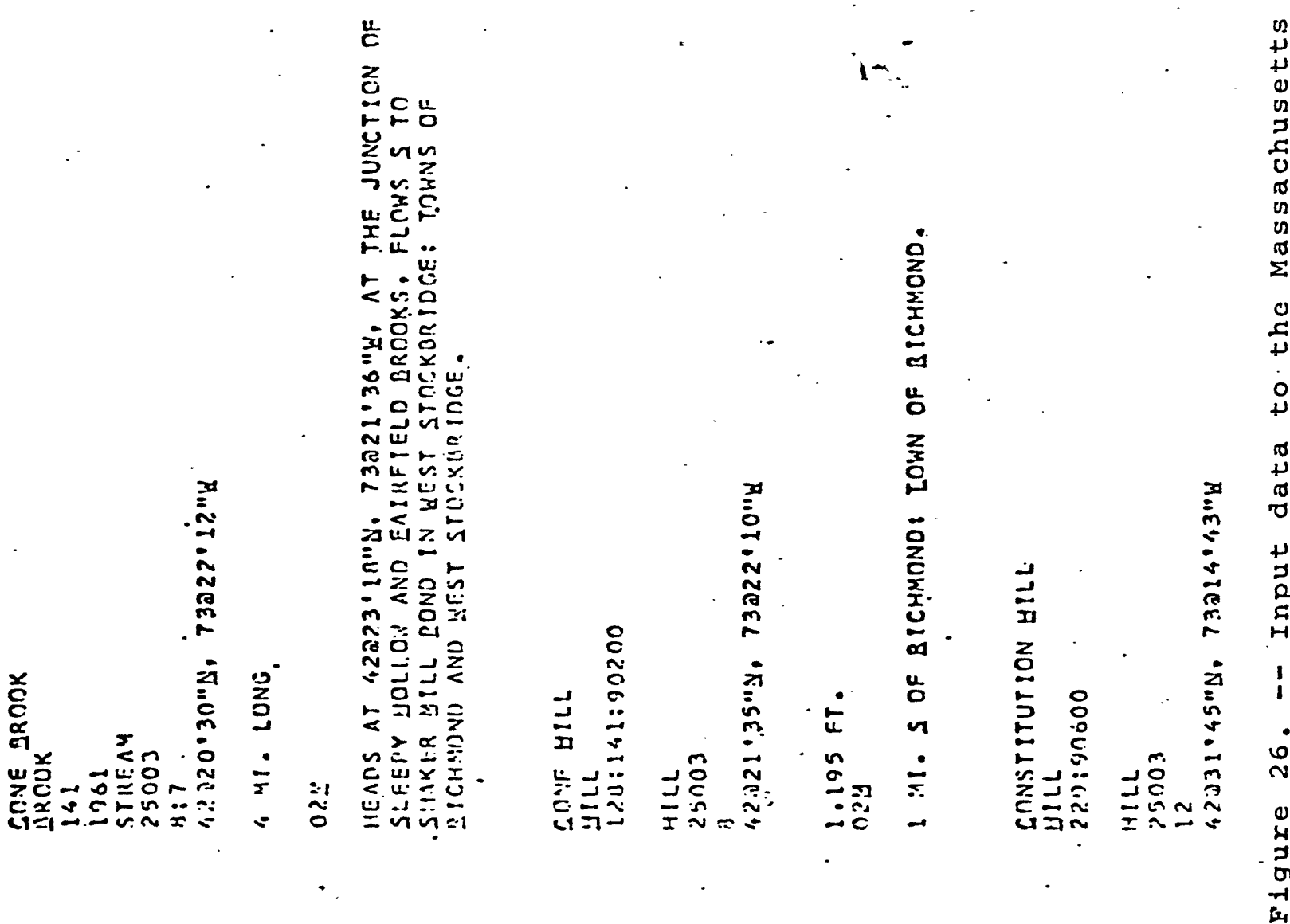

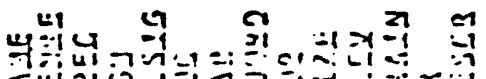

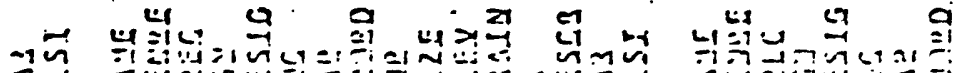

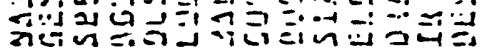

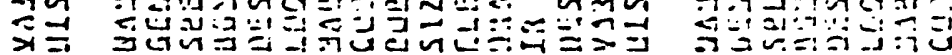




\section{MASSACHUSETTS GAZETTEER}

NAME.......... CONE BROOK

DESIGNATIOH...... STREAM

STATE CODE...... 25

COUNTY CODE...... 003

MAP NUMBER(S) ... 8; 7

COORDINATES

$$
\begin{aligned}
& \text { LATITUDE..... } 422030 \mathrm{~N} \\
& \text { LONGITUDE.... } 73 \quad 22 \quad 12 \quad \mathrm{~W}
\end{aligned}
$$

RIVER BASIN CODE. 02 IA

DESCRIPTION

HEADS AT $422318 \mathrm{~N}, 732136 \mathrm{~W}$, AT THE JUNCTION OF SLEEPY HOLLOW AND FAIRFIELD BROOKS, FLOWS S TO SHAKER MILL POND IN HEST STOCKBRIDGE; TOWNS OF RICH:IOND ANC WEST STOCKERIDGE.

GENERIC ELEMENT. . BROOK

RESEARCH CODES... 141

igure 27. - - Simulated GIPSY record from the Massachusetts Gazetteer. 
MANAGEMENT

APPLICATIONS 


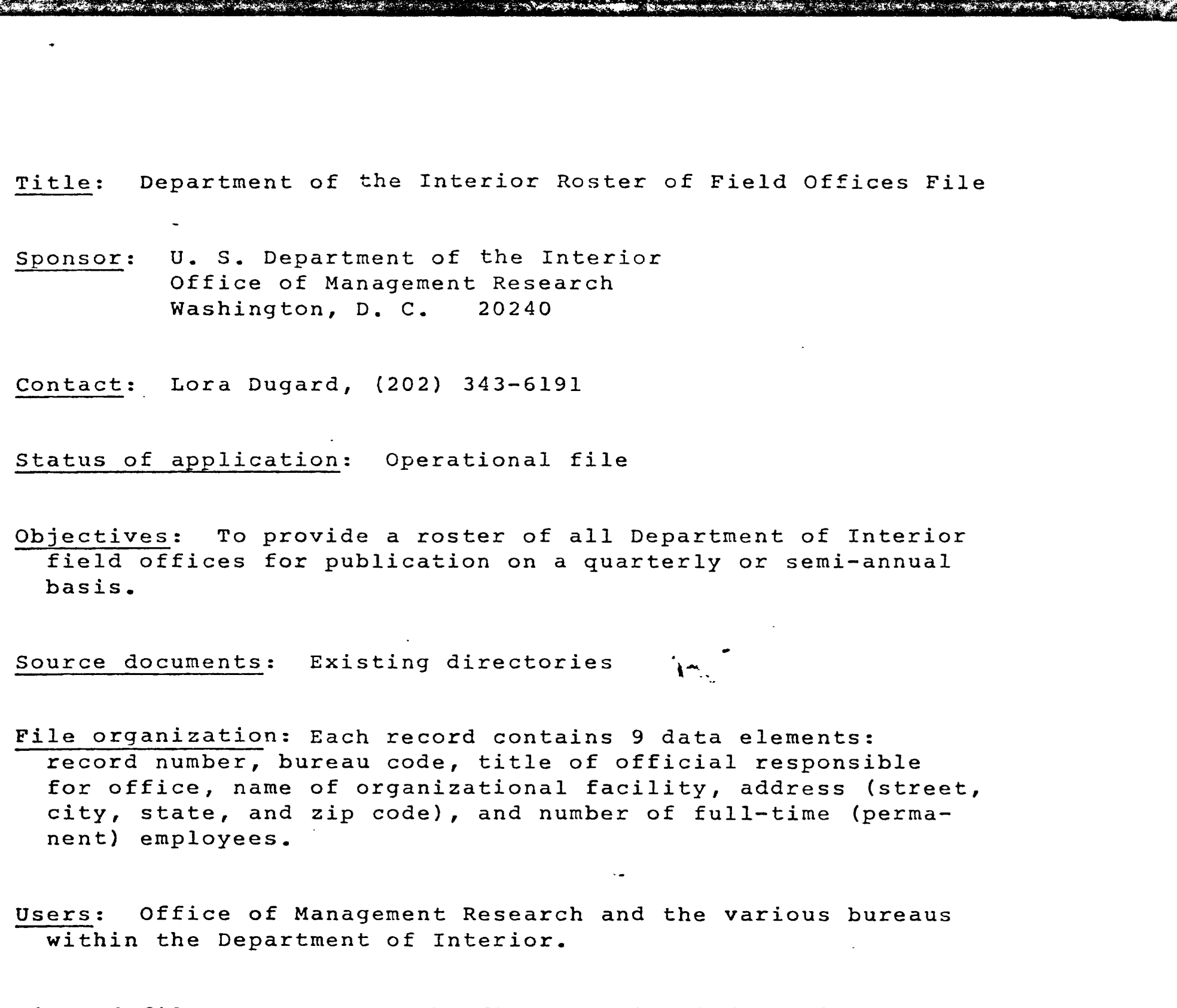

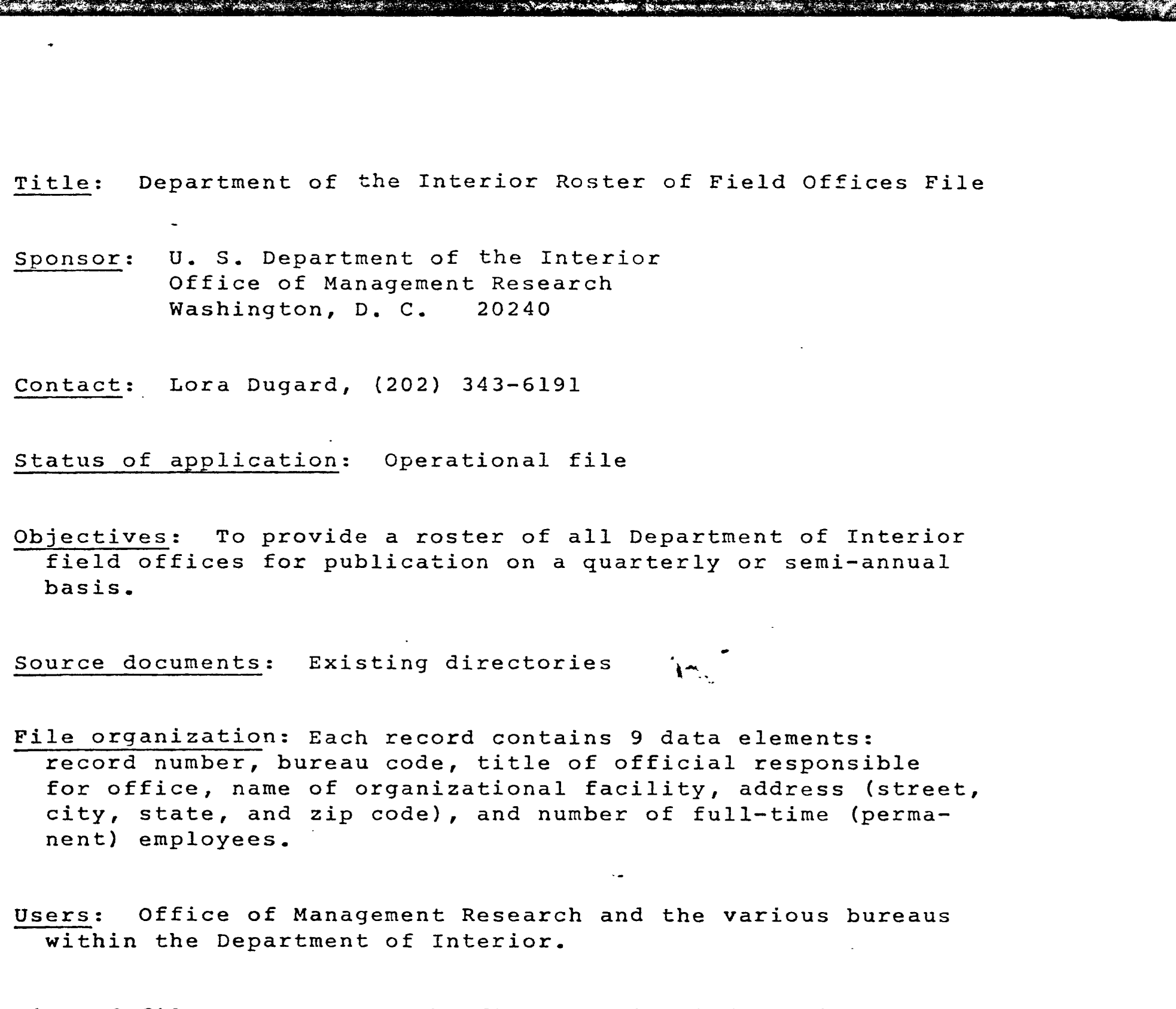

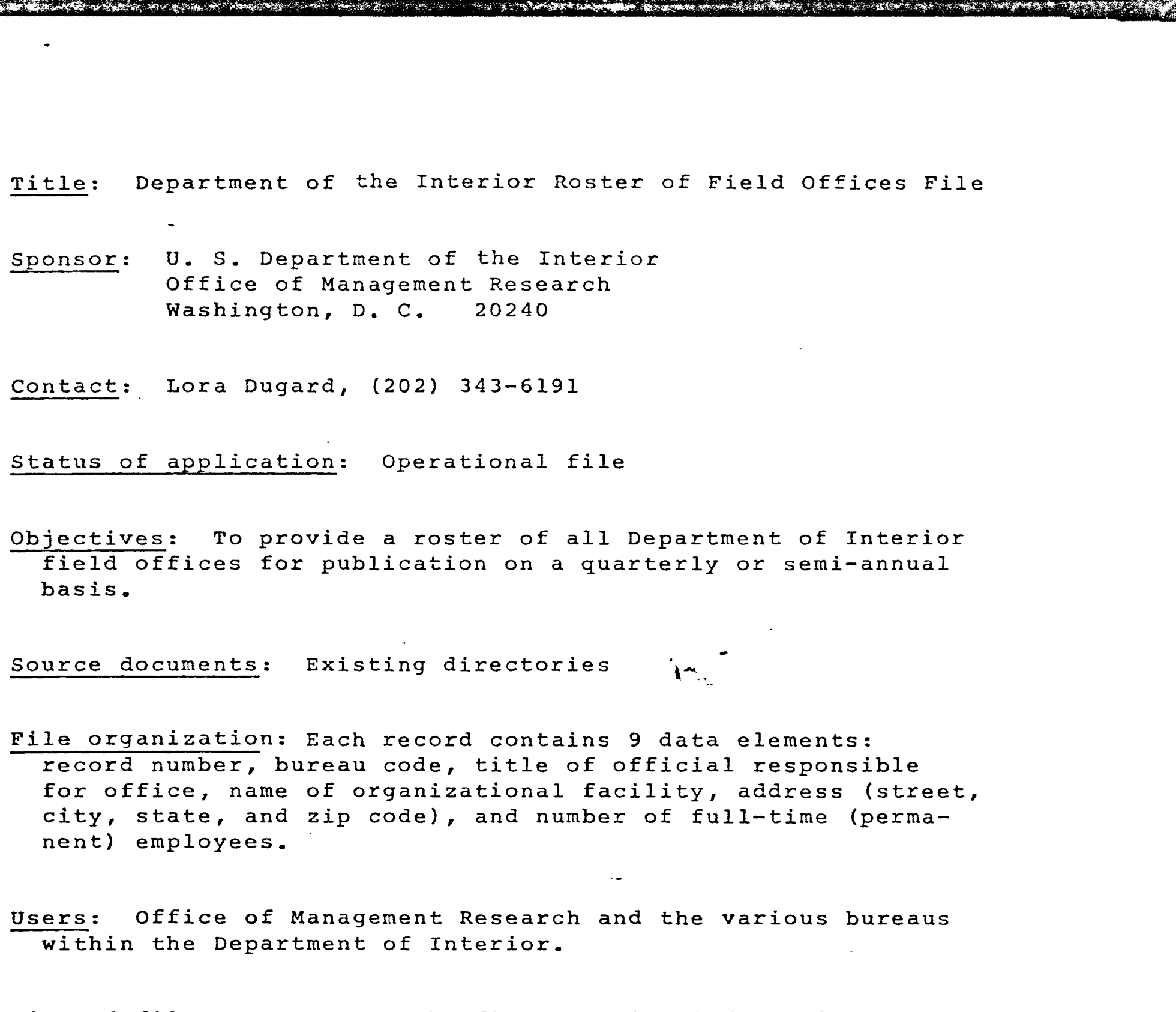

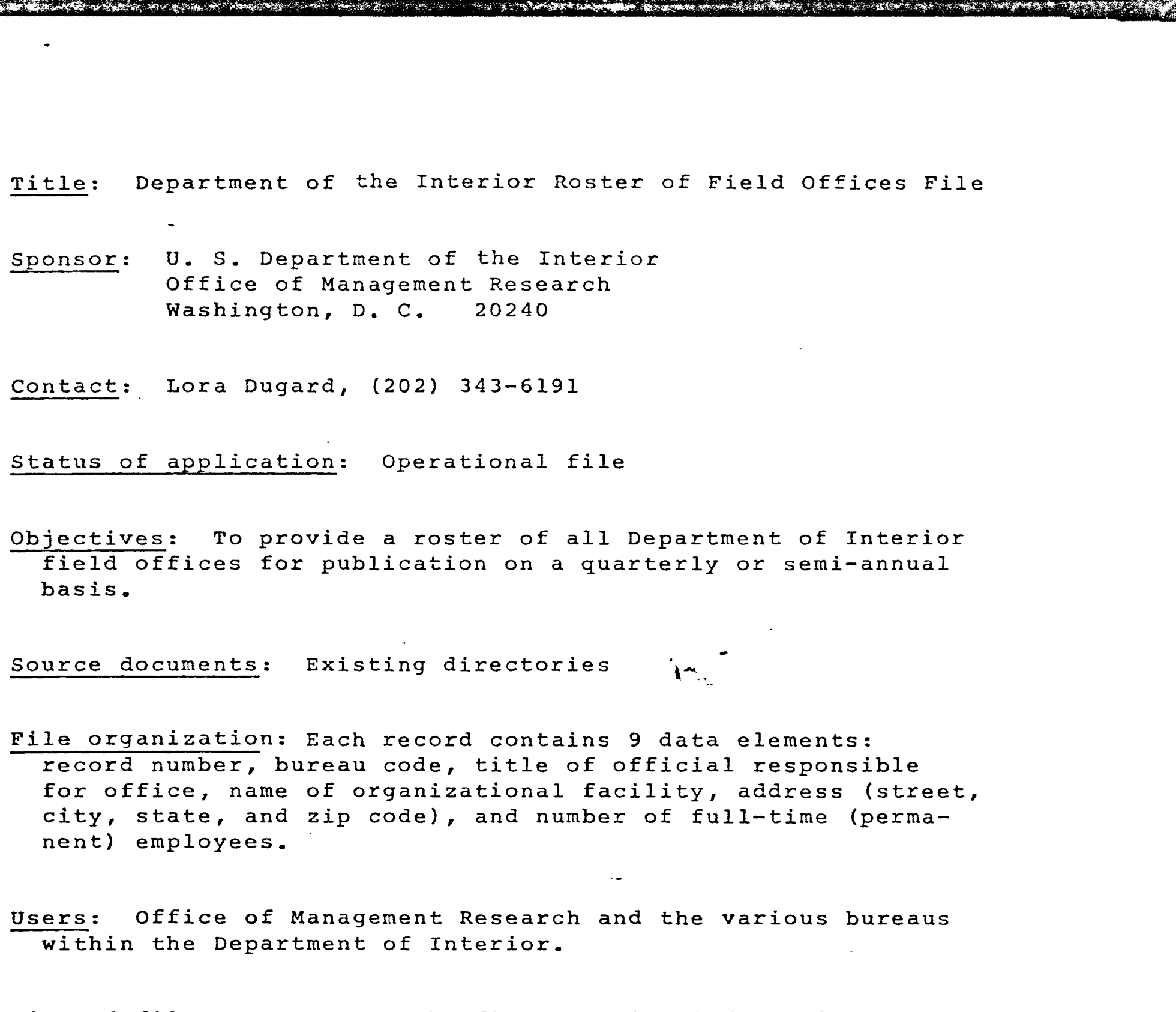

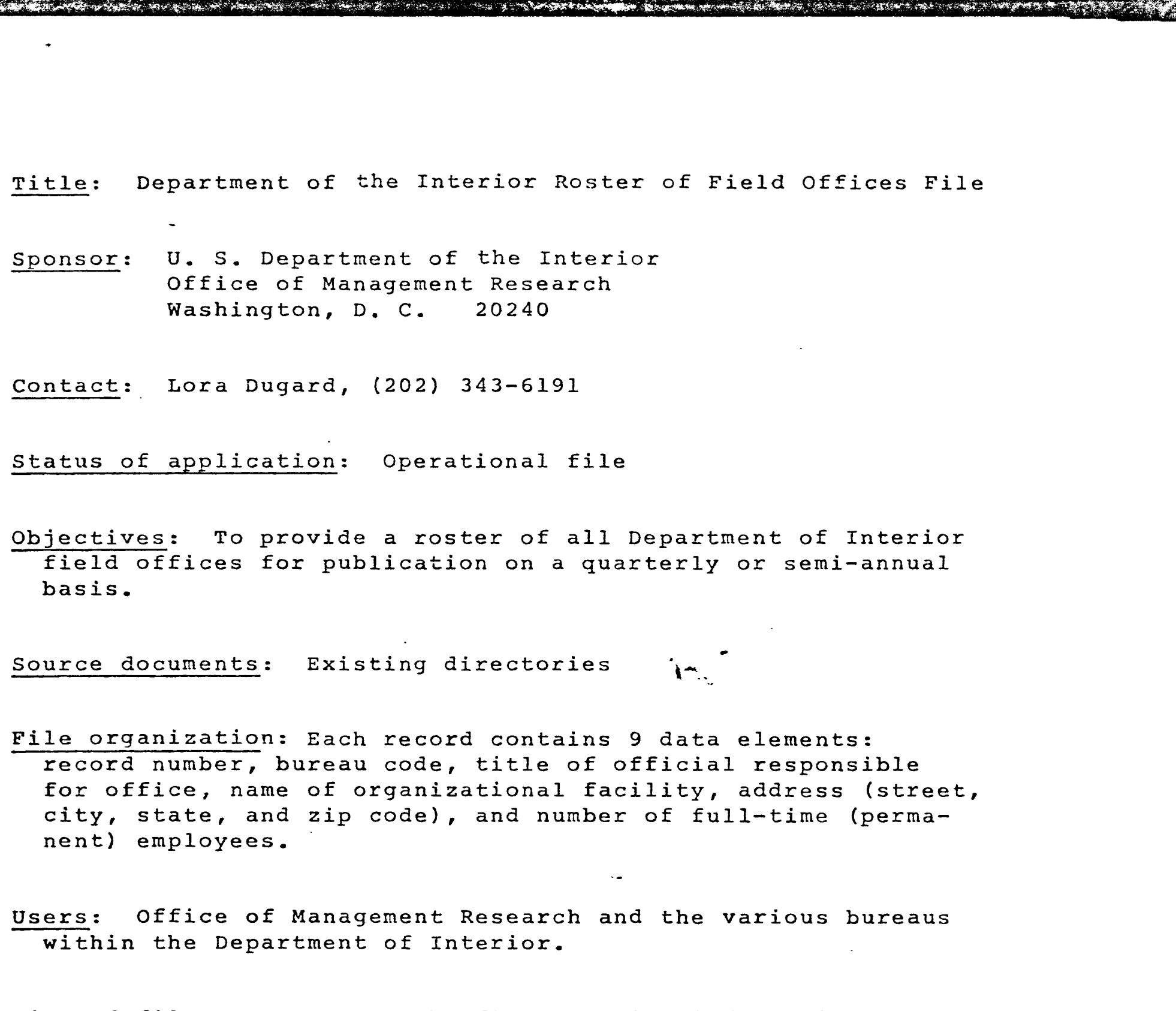

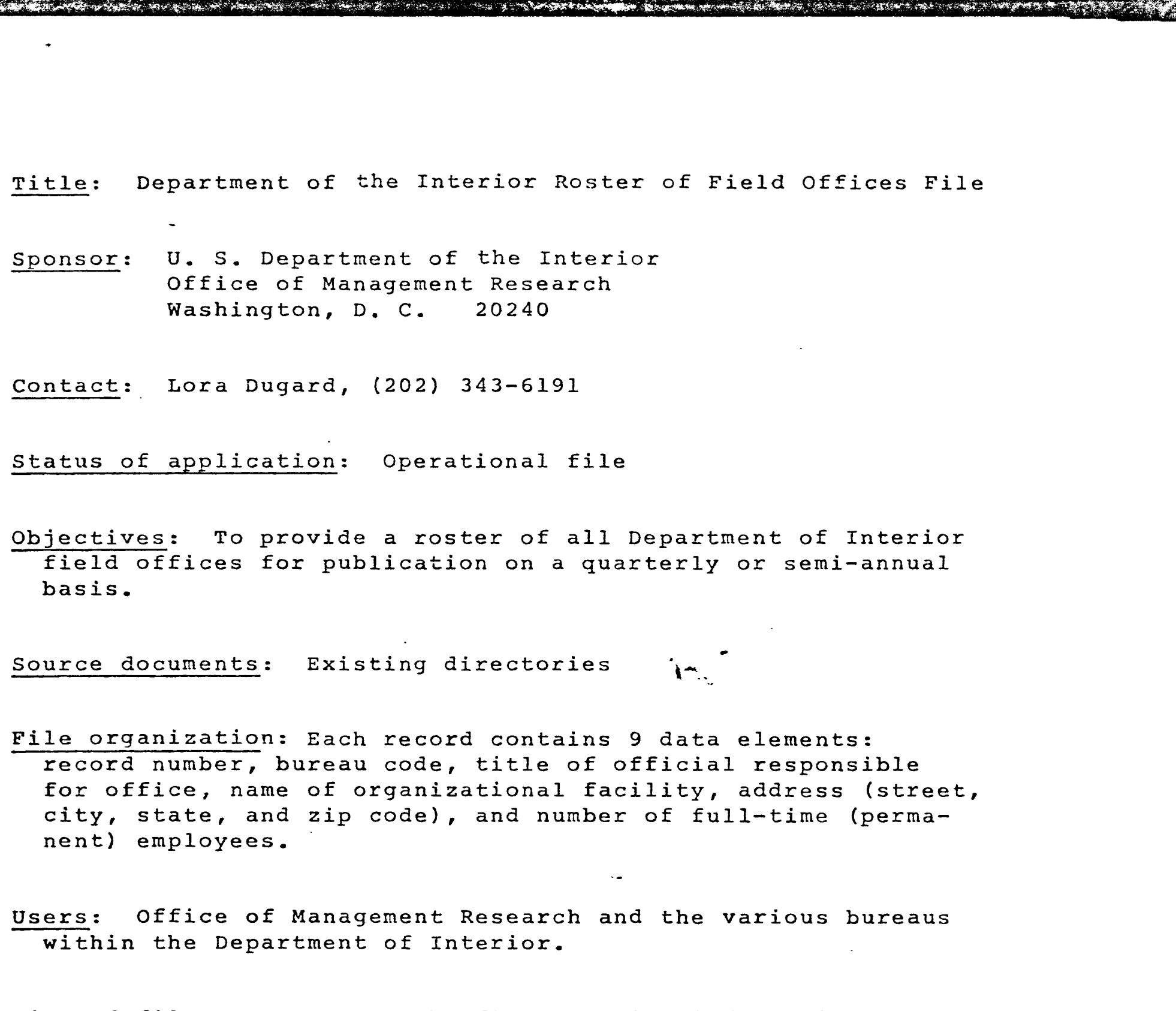

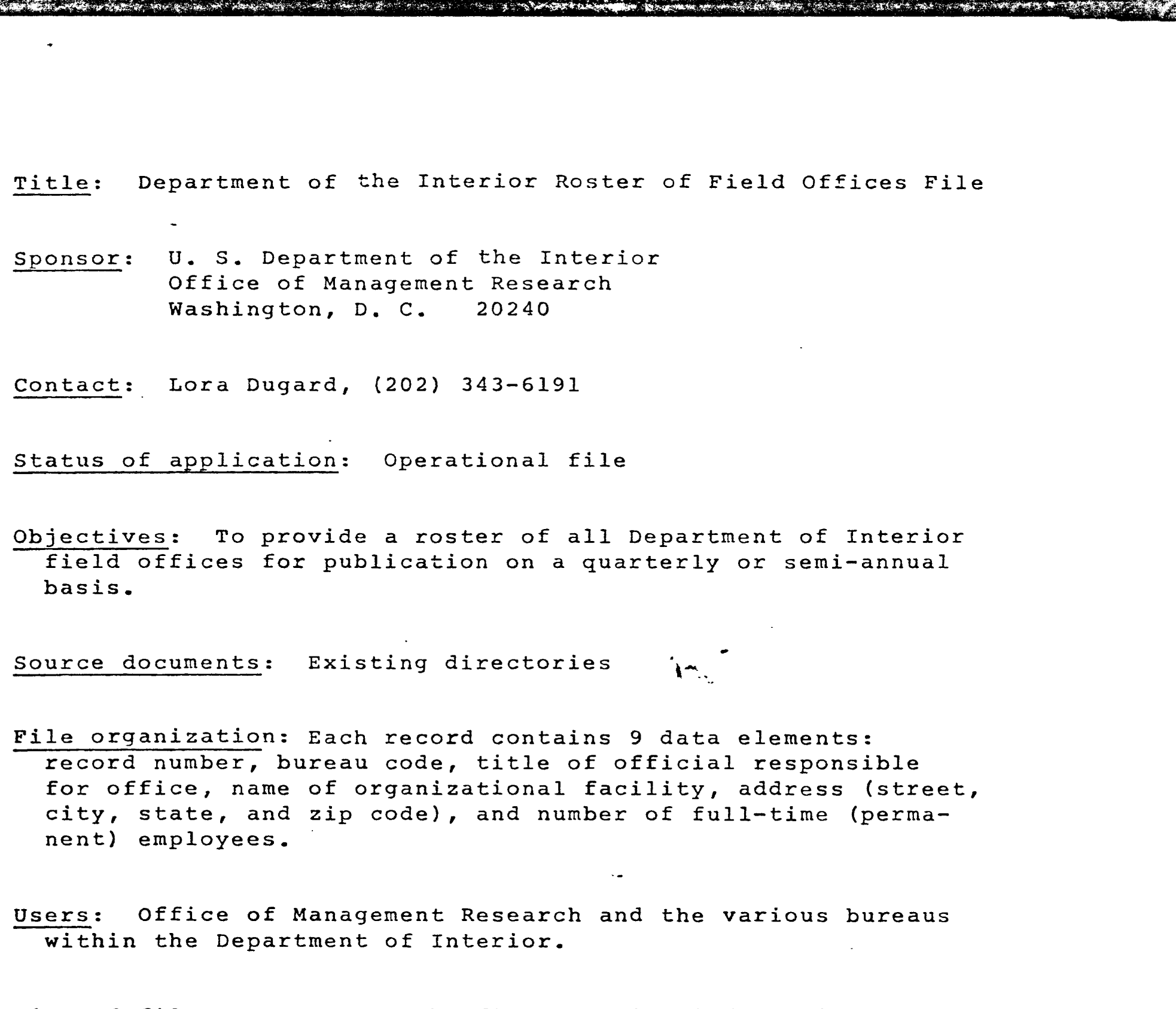

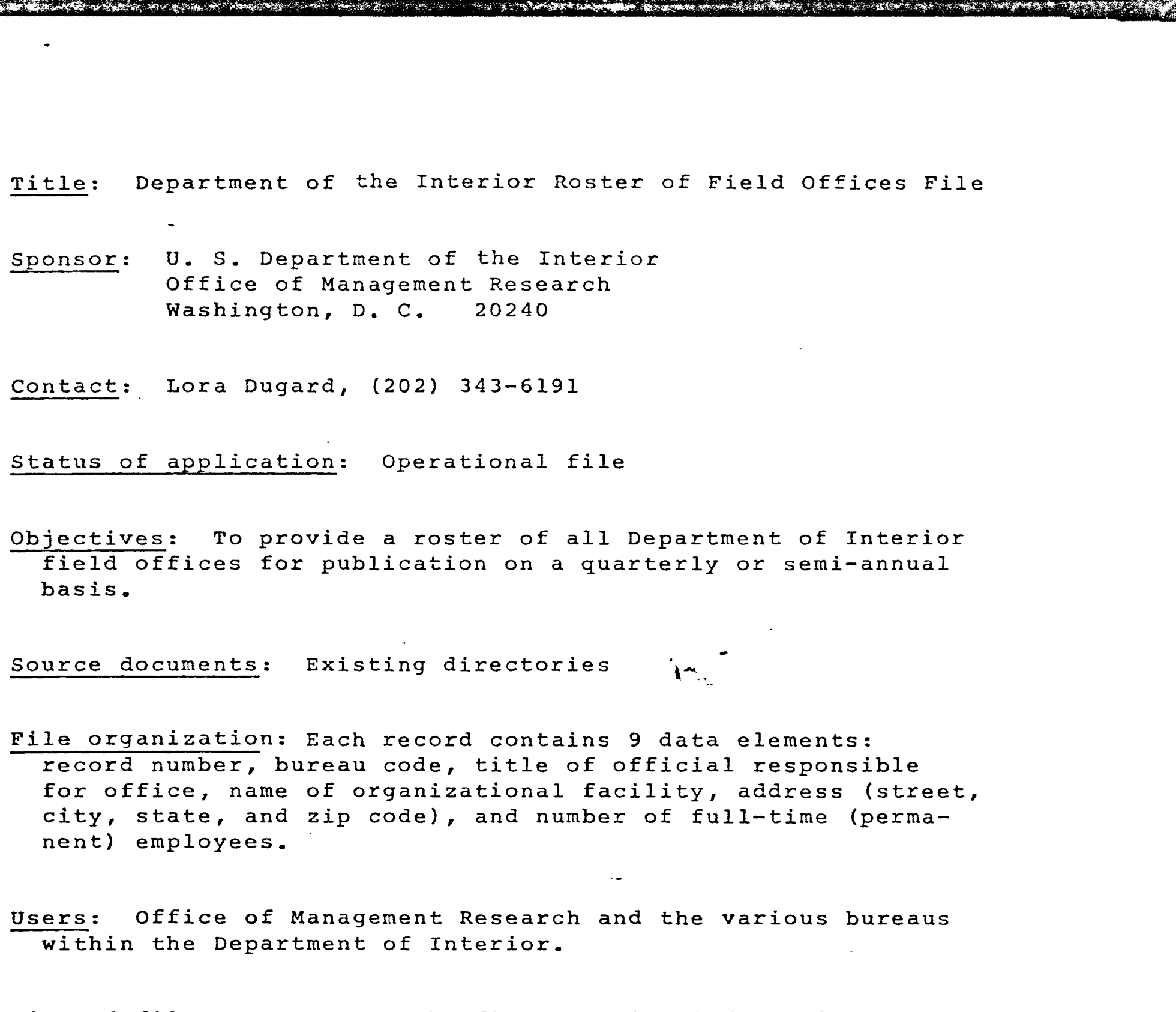

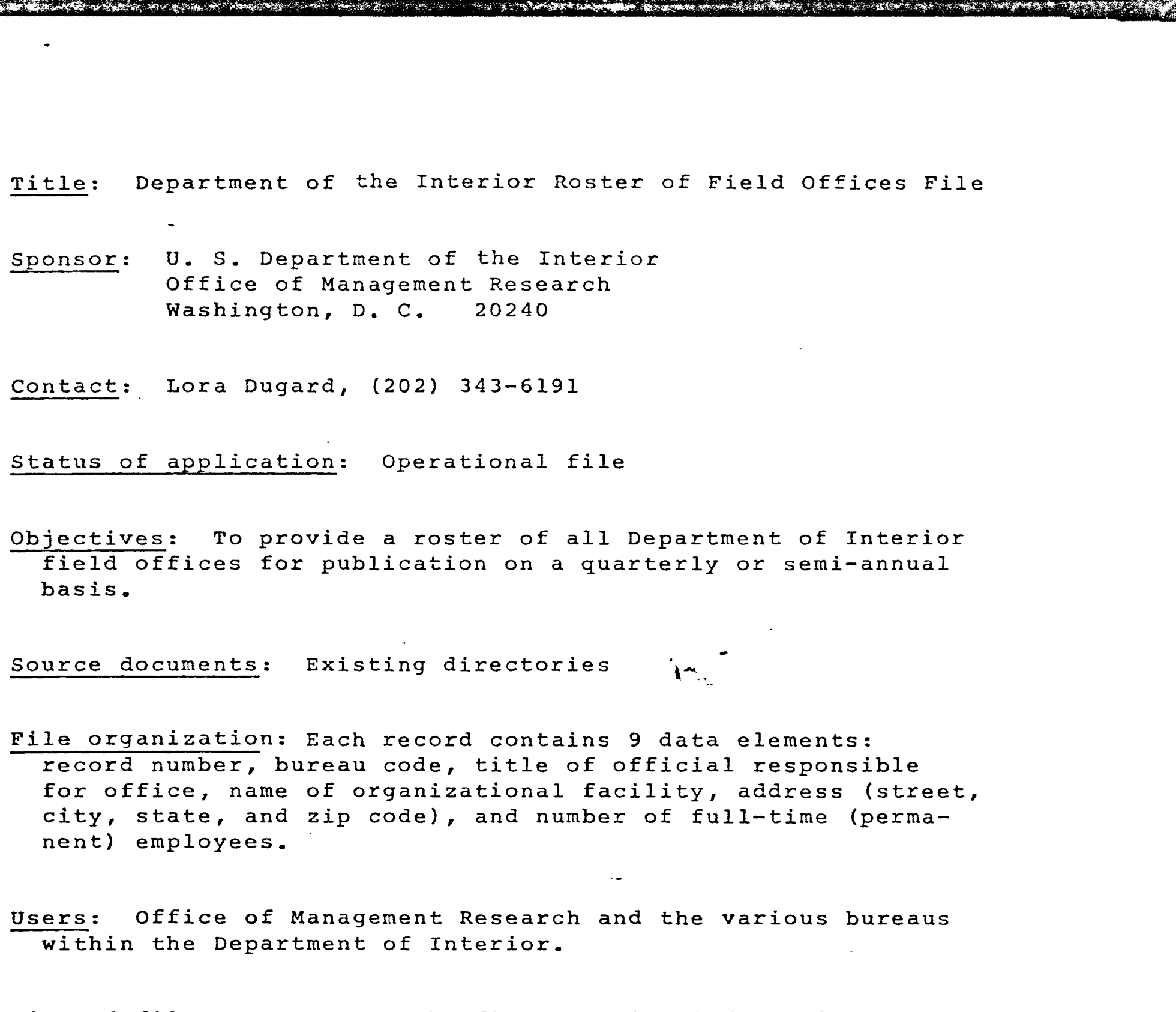

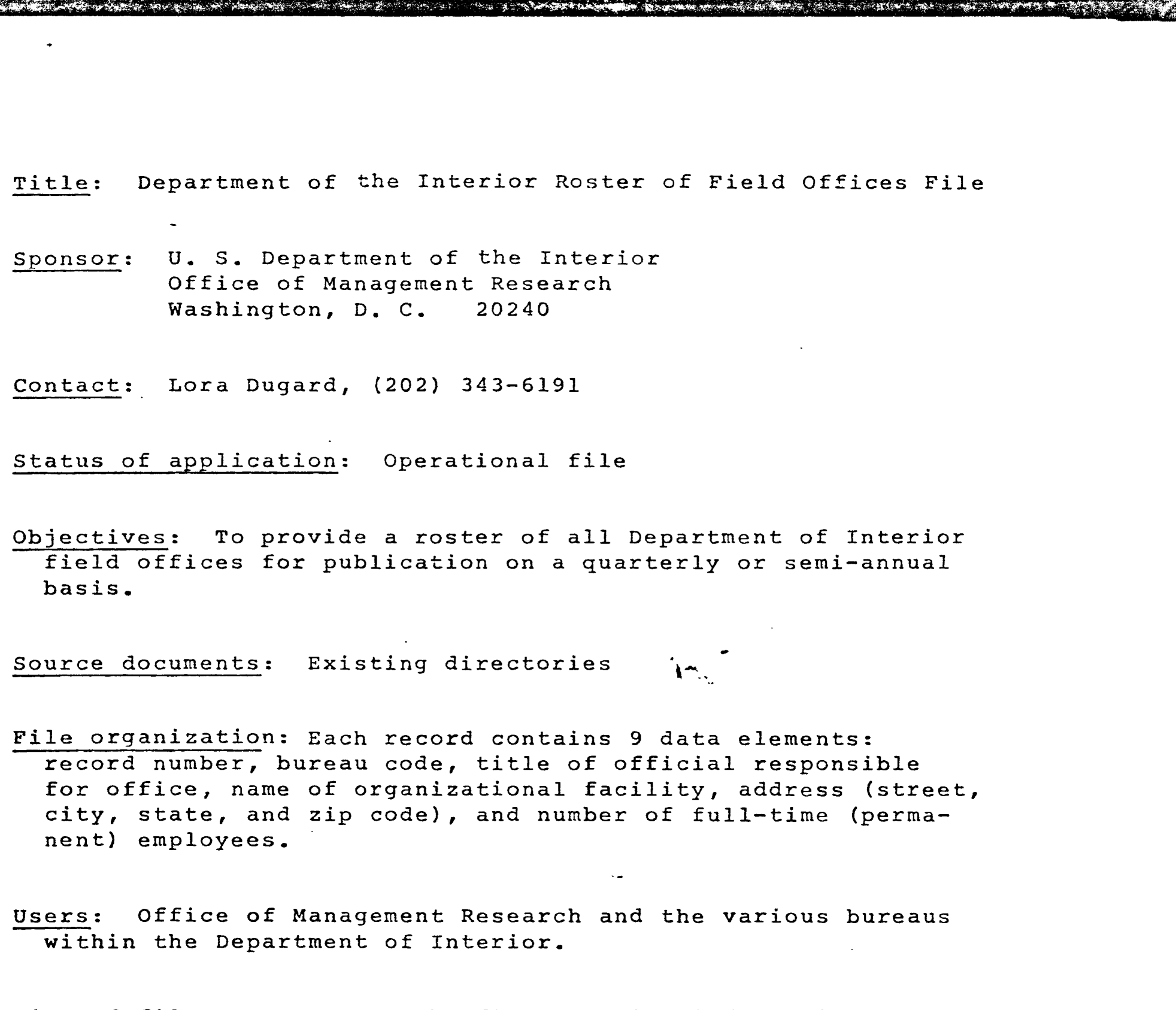

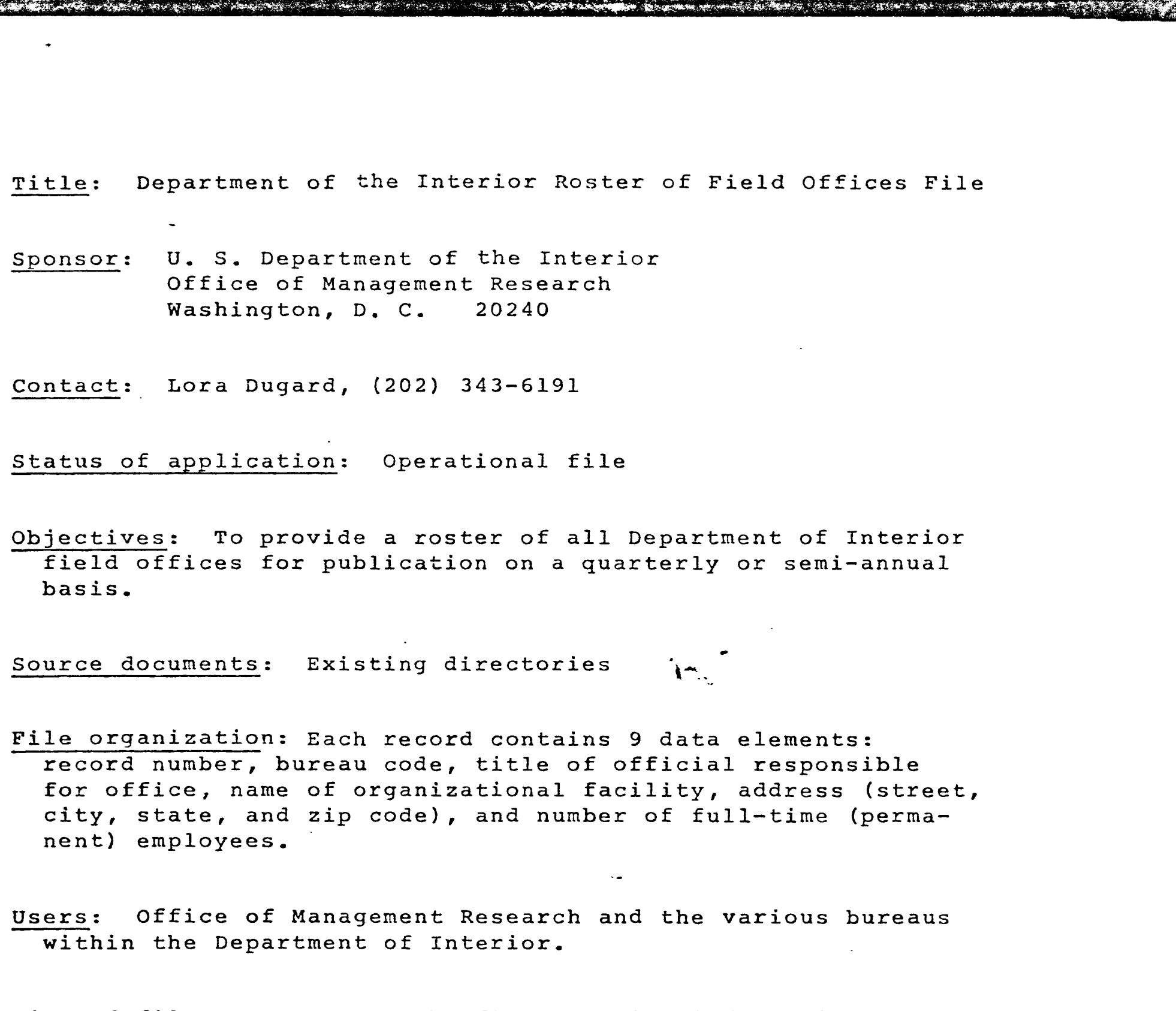

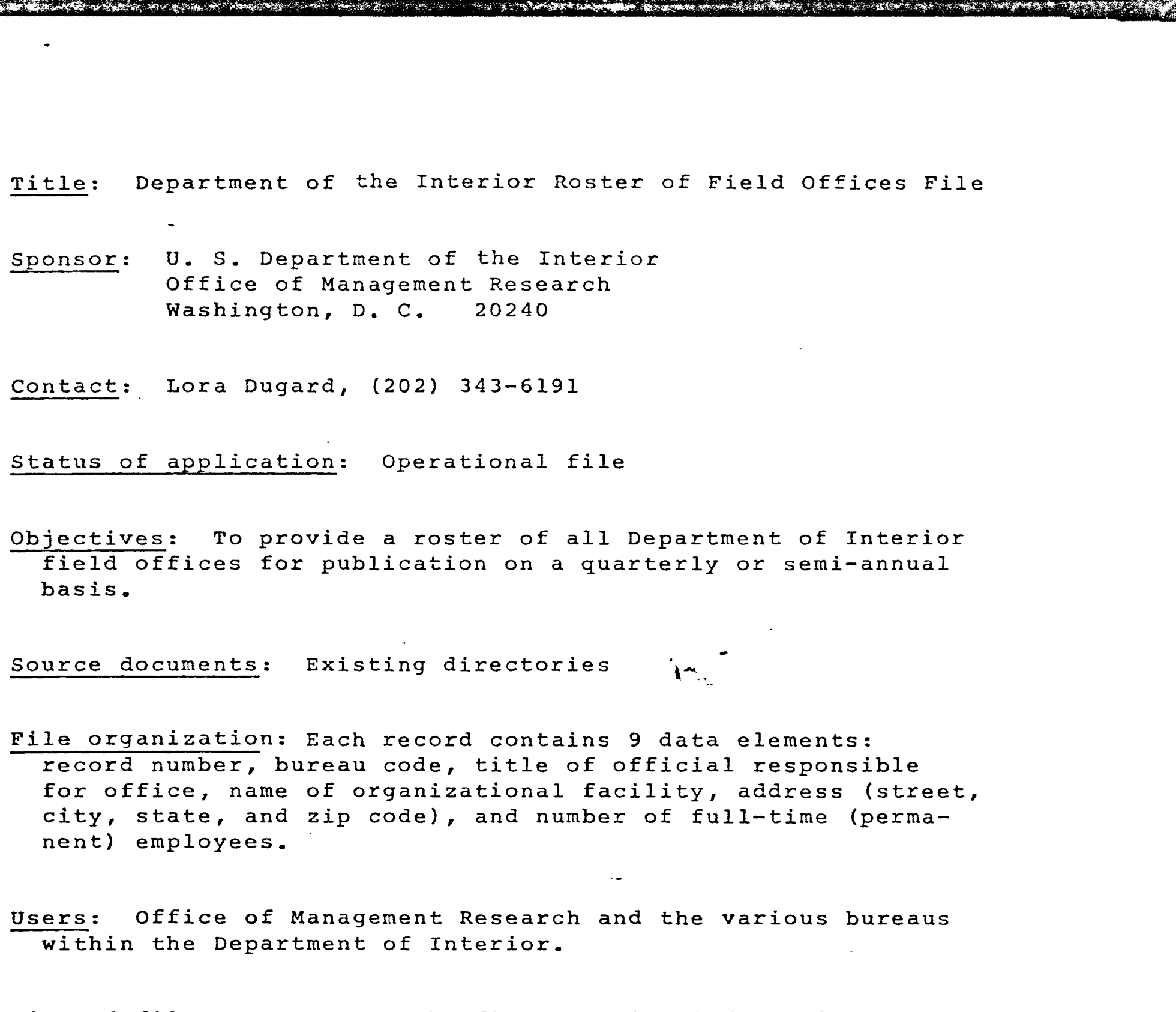

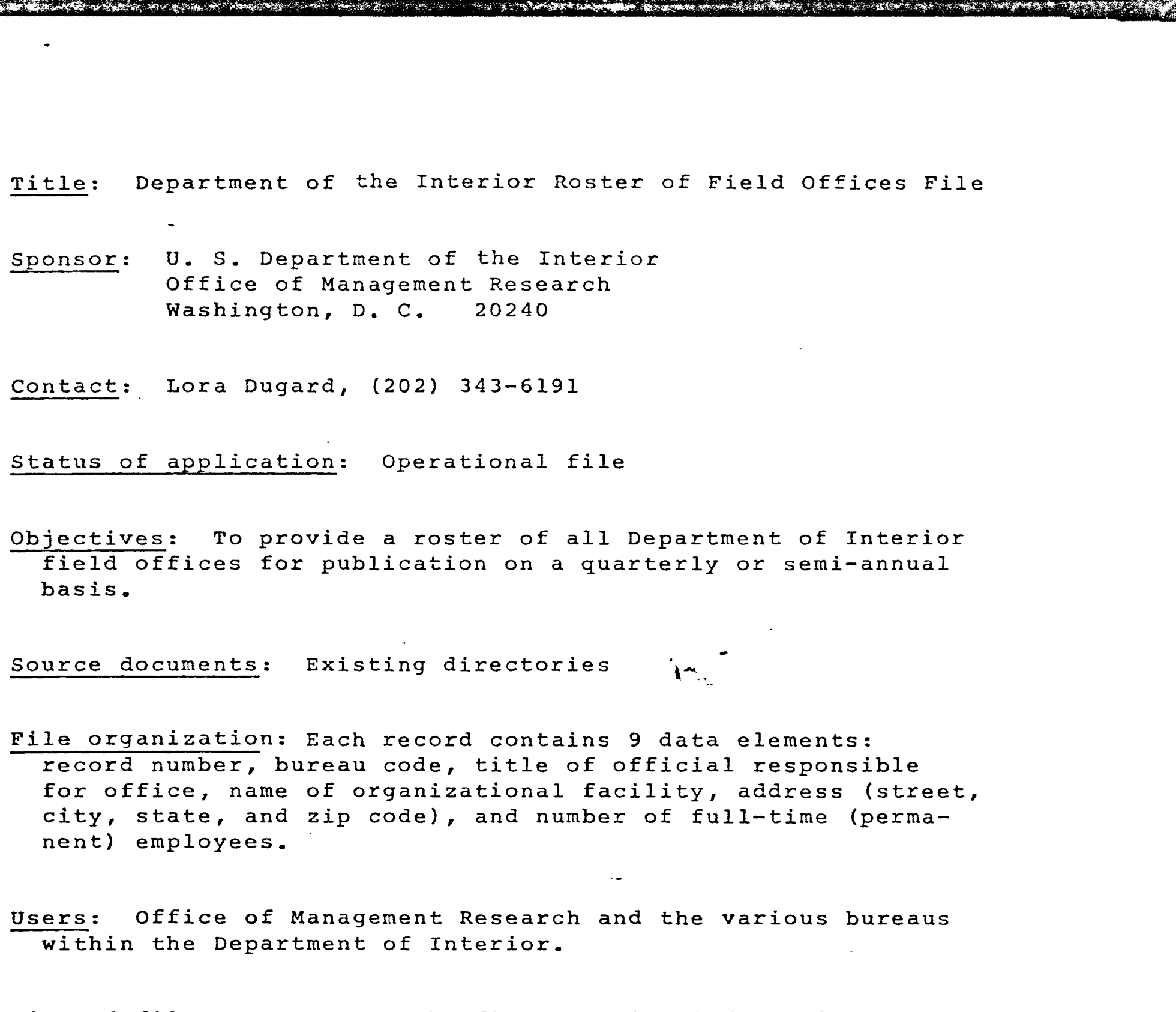

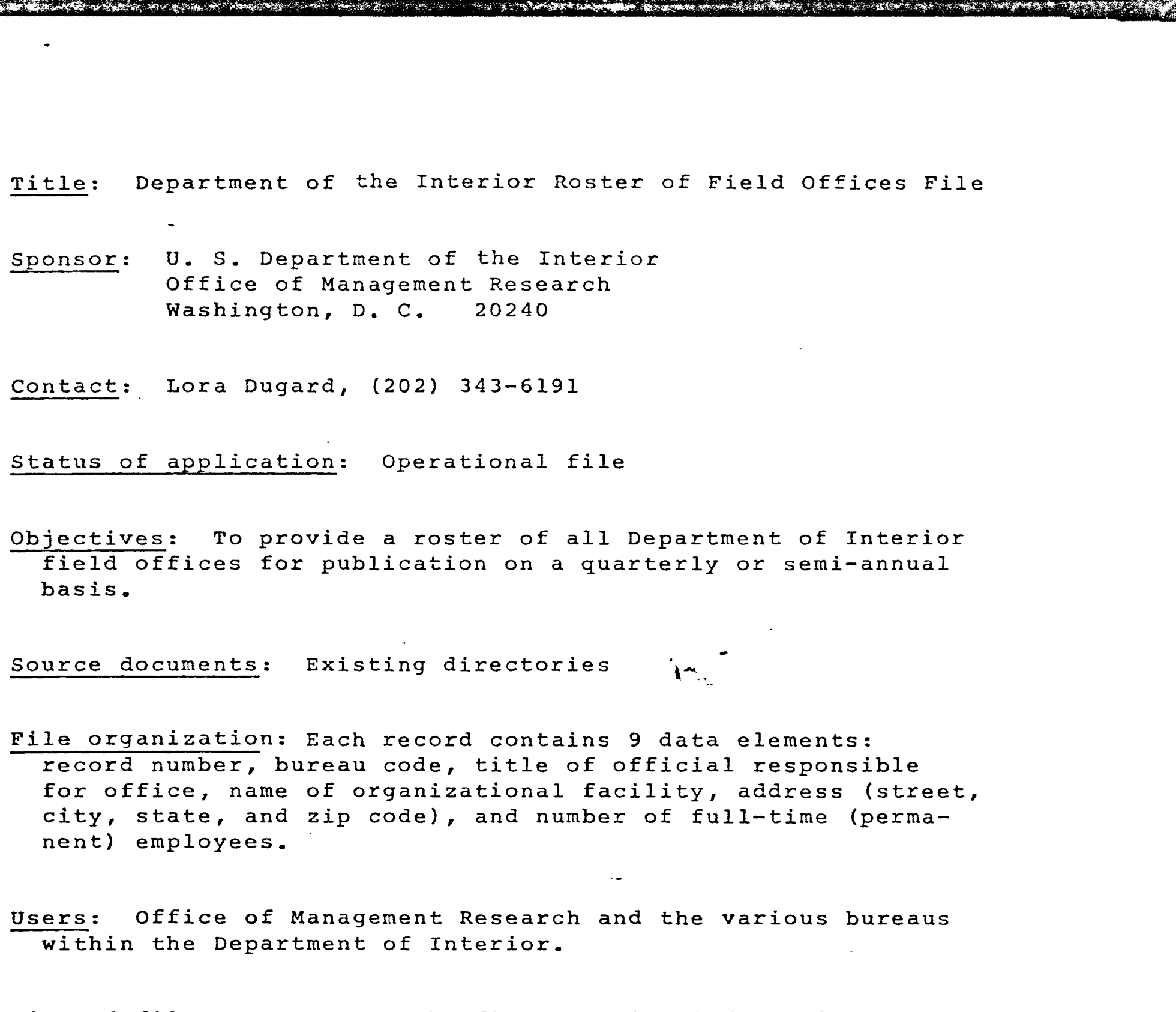

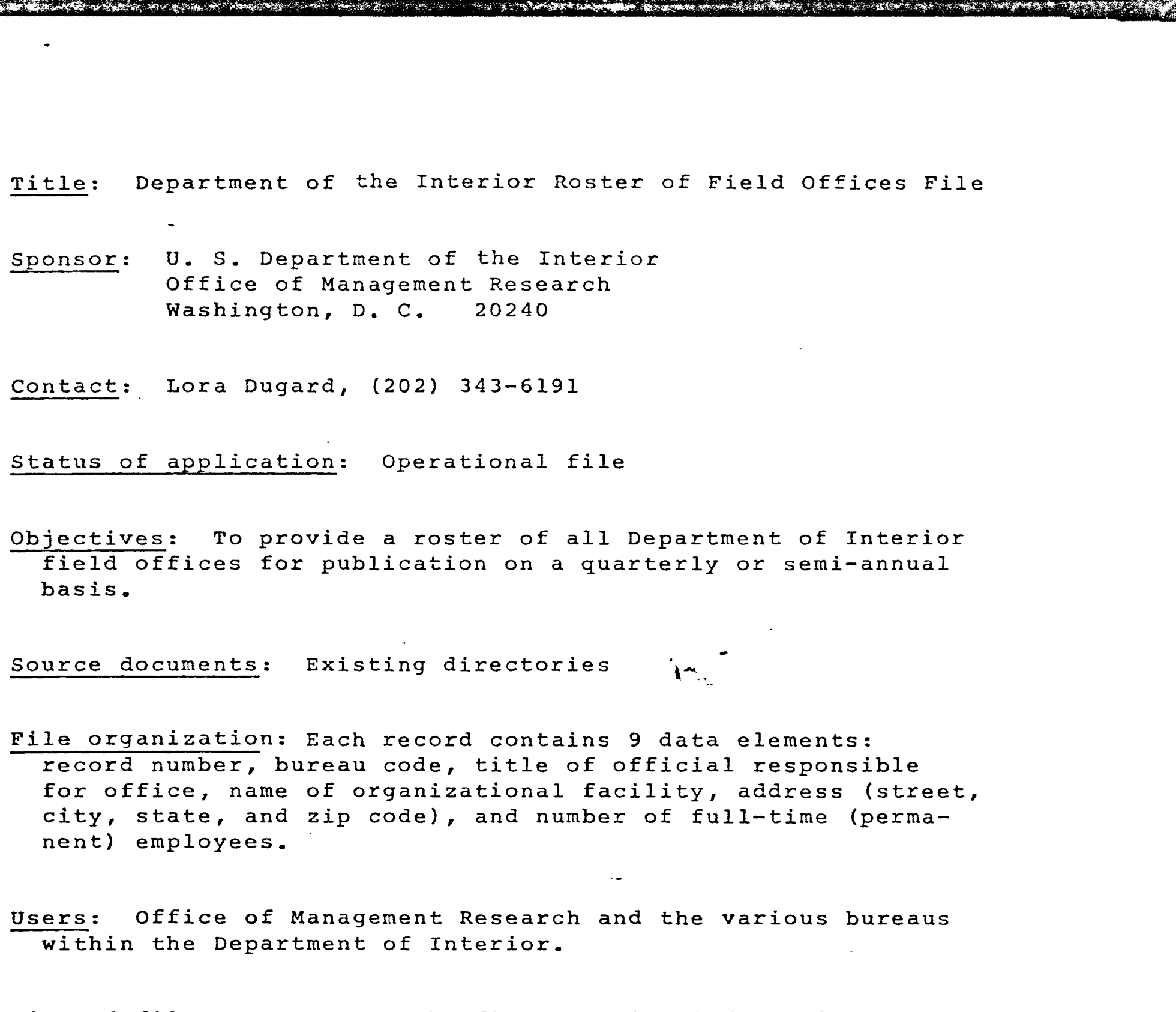

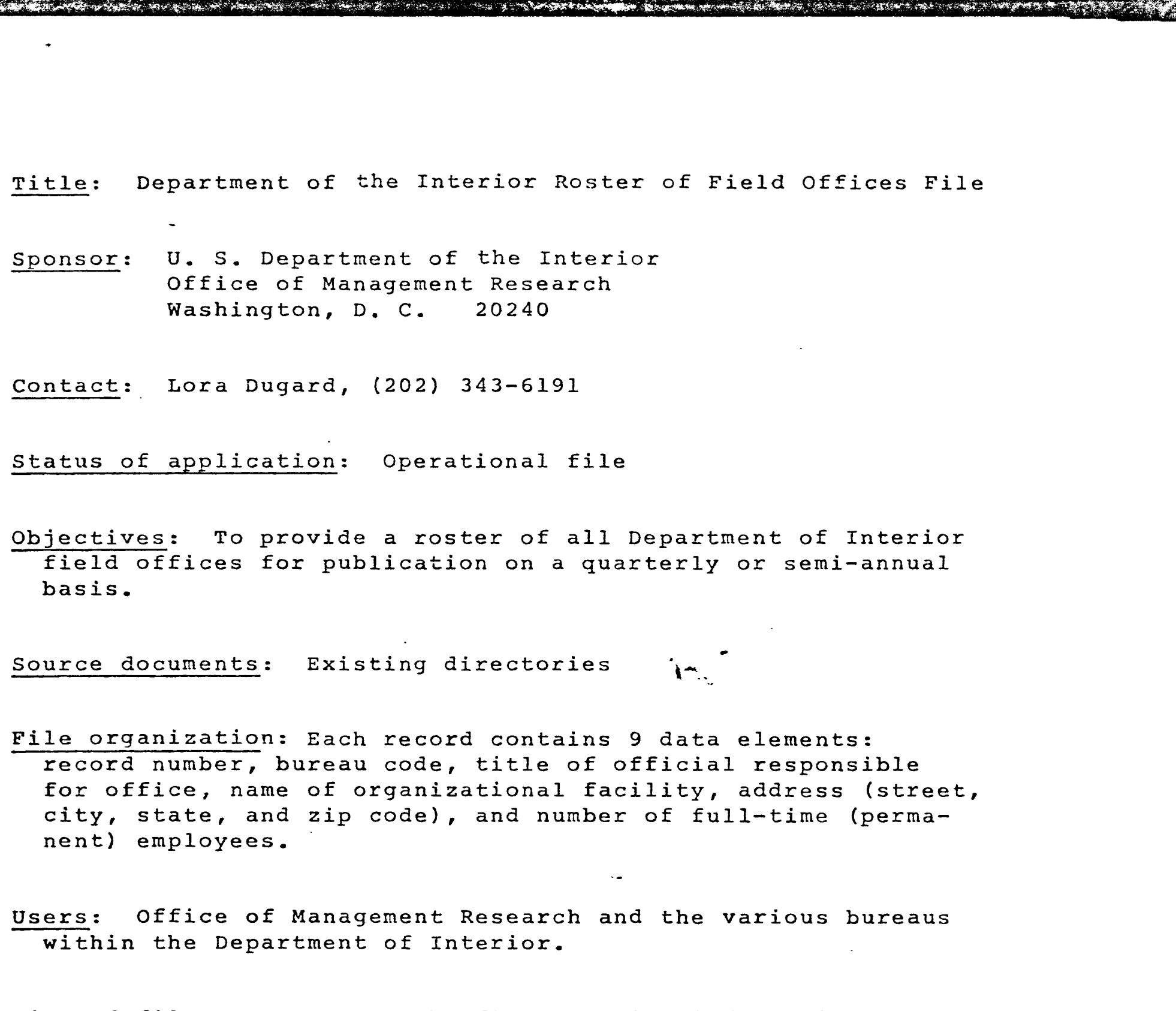

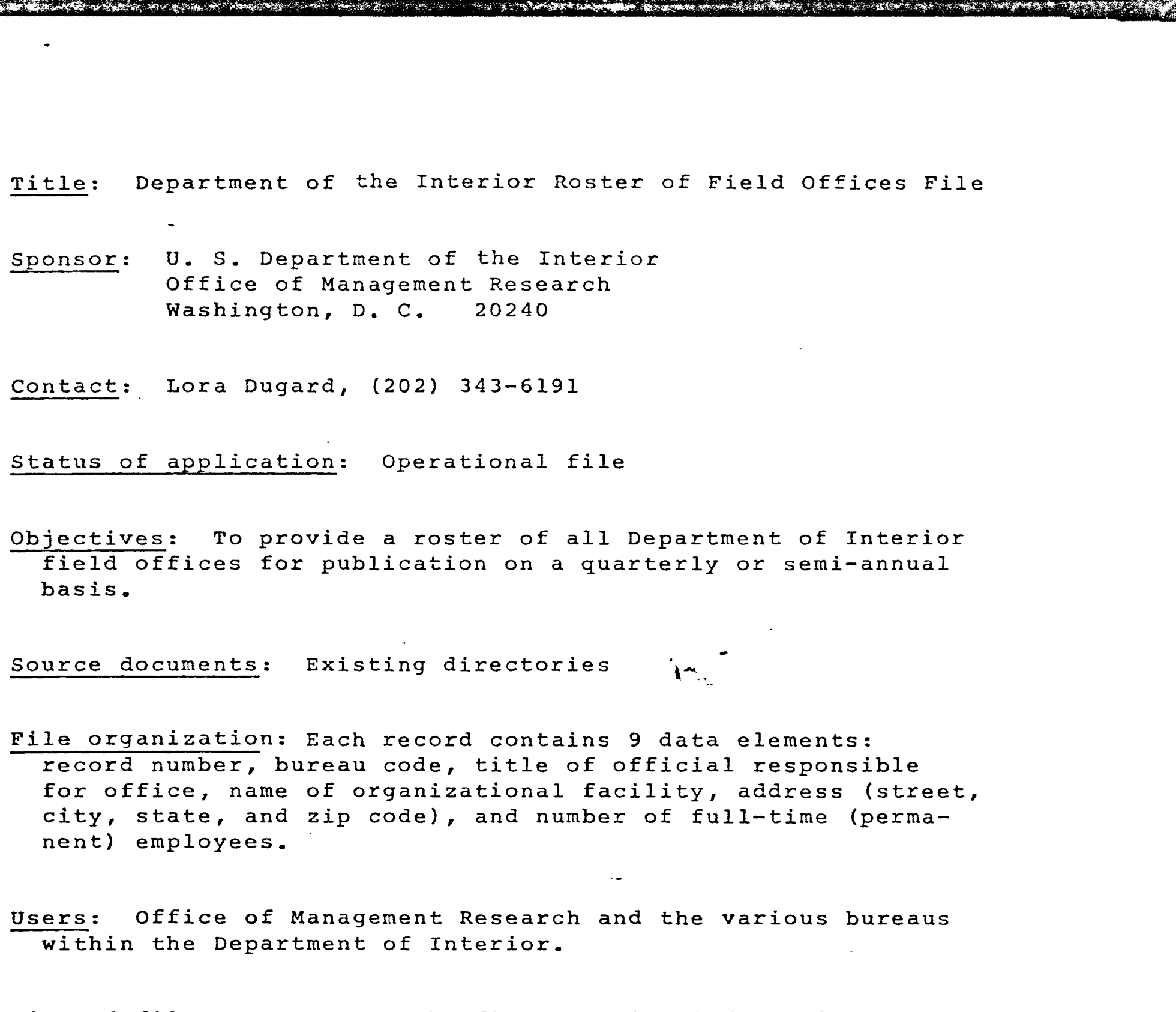

Size of file: At present the file contains information on 1.329 offices. The file will be updated quarterly or semi-annually. 
FORM- RFO EICTIONARY IISTING

INTERNAL EXTERNAL SPACIIX OPTION USASI CLEAR TEXT

\begin{tabular}{|c|c|c|c|c|c|}
\hline 00100 & 4 & 001 & 1 & 0 & TITLE OF HEAD - \\
\hline 00200 & B & 001 & 1 & 0 & MAME OF ORGANIZATION FACILITY \\
\hline 00300 & C & 001 & 1 & 0 & STREET AODRESS - \\
\hline 00400 & $\mathbf{D}$ & 001 & 1 & 0 & CITY - \\
\hline 00500 & $\boldsymbol{E}$ & 001 & 1 & 0 & STATE - \\
\hline 00600 & $\cdot \boldsymbol{F}$ & 001 & 1 & 0 & IIP COOE - \\
\hline wivo & $\mathbf{G}$ & 001 & 1 & 0 & NO. OF FULL-TIME. PERMANENT EMPLOYEES \\
\hline 00800 & $\mathbf{H}$ & 001 & 1 & 0 & SUREAU CODE - \\
\hline 00900 & $\mathbf{I}$ & 001 & 1 & 0 & RECORO NUMBER - \\
\hline
\end{tabular}

Figure 28. - GIPSY dictionary for the Department of the Interior Roster of Field offices file. 
TITLE OF HEAC - MANAEER

NAME CF ORGANIZATICN FACILITY WESTERN REGICA, CFFICE FOR EGUAL OPPORTUNI STREET ACCRESS - FEOERAL CEATER, BUILCING 67

\section{CITY - CENVER}

STATE - CO

ZIP CODE - 80225

NO. OF FULL-TIME, FERMANENT EMPLOYEES 13

BUREAU CCDE - EO

RECURC NUMBER - OCIC

RECURC NUMBER 
Title: Catalog of Federal Domestic Assistance Programs

Sponsor: U. S. Department of the Interior

office of Management Research

Washington, D. C. 20240

Contact: Lora Dugard, (202) 343-6191

Status of application: operational file

objectives: To provide information on grant and assistance programs administered by the Department of Interior in response to public inquiries. The Department uses the file for program management and analysis.

Source documents: Legislative acts and appropiriate code of Federal Regulations which establish the particular program.

File organization: Each record may contain up to 207 data elements which include: program number, title of program, name of bureau administering program, references to legislation, purpose of program, types of grant recipiants, type of assistance, procedures for initiating assistance, award procedures, deadines, time requirements for processing applications, types of reports required, measures of program accomplishment, and related program management information.

Users: Planners in Federal, state, and local governments as well as the general public.

Size of file: At present the file contains information on 127 programs administered by the Department. The file is updated quarterly. 

PRCGRAA NUMBER - INPS - 1

OFFICIAL TITLE OF PROGRAA - DISPOSAL OF SURPLUS WILDLIFE

NAME DF BUREAU/DIVISIDA - NATIONAL PARK SERVICE

ACTS A:10 CITATIOYS

FEDERAL PROPERTY AND ADYIINISTRATIVE SERVICES ACT OF 1349,63 STAT 341 CFR $101-43.3,44.3,45.3,45.5$

PUPPJSE - IN MAIMTAIMING PARK WILOLIFE POPULATIONS AT PROPER LEVELS, HIGH PRISRITIES ARE GIVEN TO THE DISPUSAL DF LIVE SURPLUS MUIMALS TO MUNICIPAL ZOOS FDR DISPLAY PJRODSES; STATE AGENCIES ANU OTHER

GRGANILATIUNS FOR RESTGCKINA GAME KANGES.

RELATIONSHIPS VITH

STATE AGEPIES -

COU:TTIES -

METRO AGEVICIES -

CITIES -

UUIVERSITIES AND COLLEGES -

INDIAN TRIRAL CLUNCILS -

in.

ASSI STA:ICE RELATIDNSHIPS

DISPJSAL UF FEDERAL SURPLUS PPIDPERTY -

PROÉRAIA APPLICAOILE TO ALL STATES -

WHJ INITIATES ACTION - SUPERINTENDENT DETER:AINES KINDS AND NUMBER UF ANIMALS THAT ARE SURPLUS AND FILLS REQUESTS FUR SUCH ANIMALS BASED ON THE FOLLUNING ESTABLISHED PRIJRITIES FOR THE DISPOSAL OF LIVE ANIMALS: 1. MUNICIPAL ZOUS; 2. INOIAN RESERVATIUIV OR OTHE? FEDERAL AGEINCIES; 3. STATE JAME AGENCIES; 4. LUCAL GOVERNIENT BDDIES; 5. PRIVATE ORGANIZATIONS.

VJCABULARY REFERENCE - REQUEST.

CEG NUMBER - 15.900

USE A.VD USE RESTRICTIJNS - RESTJCKING OF WILDLIFE RANGES - ZOO OISPLAY ANIMALS - SCIENTIFIC SPECI.1E!SS - WELFARE FOBD PRDGRAIS

APPLICANT ELIGIBILITY REQUIRENENTS - STATE, LCCAL OR MUNICIPAL GOVERIVMENT; EDUCATIDIVAL UR OTHER TAX-SUPPORTED INSTITUTIJN.

BENEFICIARY ELIGIBILITY - DETER:AINEO BY STATE OR LGCAL GUVERVMENT; E.G., LICENSED HU:IER, WARD OF STATE, ETC.

PRE-APPLICATION CCORDINATION - ANNUAL ESTIMATES OF THE TYPES AND NUIUERS DF AHIMALS THAT WILL 3E SURPL:JS ARE REPJRTED $3 Y$ IIVDIVIOUAL SERVICF UNITS TO THE WASHINGTON OFFICE AIVIUALLY. STOCKIHG DF WILD ANIMALS :UST BE LN ACCORDANCE WITH A PLAN JOINTLY APPKOVED $3 Y$ THE

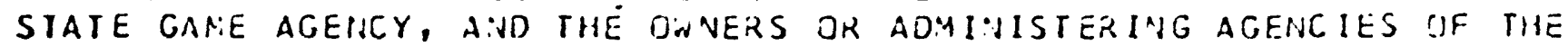

Figure 31. -- GIPSy record from the catalog of fedrial

Domertic Assilitance Prorgan; file. 
Title: Grant-in-Aid Programs. File (OMB Form 240)

Sponsor: U. S. Department of the Interior

Office of Management Research

Washington, D. C. 20240

Contact: Lora Dugard, (202) 343-6191

Status of application: Operational file

objectives: To monitor information on recipients of grantsin-aid being provided to the office of Management and Budget and to answer questions about various programs.

Source documents: OMB Form 240

Pile organization: Each record may contain up to 38 data elements which include: record number, bureau grant number, purpose, grantee's name (including address and type of organization), dates of various actions taken on grant, type of action, and funding.

Users: Office of Management Research analysts and bureau personnel.

Size of file: At present the file contains information on 1.097 grants. The file is updated as necessary. 


\begin{tabular}{|c|c|c|c|c|c|}
\hline \multirow[b]{2}{*}{ INTERHAL } & \multirow[b]{2}{*}{ EXTERNAL } & \multirow[b]{2}{*}{ SPACING } & \multicolumn{2}{|c|}{ FORA- OMS } & DICTIONARY LISTING \\
\hline & & & OPTION & USASI & CLEAR TEXT \\
\hline 00005 & 02 & 010 & 1 & 0 & RECORD NUMBER - \\
\hline 00010 & 03 & 010 & 1 & 0 & SUREAU/REGION - \\
\hline 00015 & $04 A$ & 010 & 1 & 0 & BUREAU GRANT NUHBER - \\
\hline 00020 & $04 \mathrm{C}$ & 010 & 1 & 0 & PURPOSE - \\
\hline 00025 & $05 A$ & 010 & 1 & 0 & GRANTEE"S NAME - \\
\hline 00030 & 058 & 010 & 1 & 0 & GRANTEE'S STRTE - \\
\hline 00035 & osc & 010 & 1 & 0 & GRANTEE'S IIP CODE - \\
\hline 00040 & 06 & 010 & 1 & 0 & GRANTEE TYPE \\
\hline $00 c 45$ & 064 & 015 & 1 & & STATE \\
\hline 00050 & 068 & 015 & 1 & & INTERSTATE \\
\hline 00055 & $06 \mathrm{C}$ & 015 & $\mathbf{I}$ & & COUNTY \\
\hline 00060 & 060 & 015 & 1 & & citr \\
\hline 00065 & OGE & 015 & 1 & & SCHOOL DISTRICT \\
\hline 00070 & O6F & 015 & 1 & & SPECIAL UNIT - \\
\hline 00075 & 066 & 015 & 1 & & COMmUntTY IC̃Ttion \\
\hline $\operatorname{coc} \theta 0$ & $06 \mathrm{H}$ & 015 & 1 & & SPOKSOREO ORGANIZATION \\
\hline 00085 & 061 & 015 & 1 & & OTHER \\
\hline 00090 & or & 010 & 1 & 0 & APPLICATION RECEIPT ORTE - \\
\hline 00095 & co & 010 & $\mathbf{l}$ & 0 & APPLICATION RCTION DATE - \\
\hline 00097 & 08A & 010 & $\mathbf{z}$ & 0 & EFFECTIVE STARTING DRTE - \\
\hline 00098 & 088 & 010 & 1 & 0 & EMOING DATE - \\
\hline 00100 & 09 & 010 & $\mathbf{1}$ & 0 & APPLLICATION ELAPSED TIME - \\
\hline 00102 & 10 & 010 & 1 & 0 & COLlatimg sequence date - \\
\hline 00105 & 11 & 010 & 1 & 0 & TYPE OF ACTION \\
\hline 00110 & 114 & 015 & 1 & & MEN GRANT \\
\hline 00115 & 118 & 015 & 1 & & CONTINUATION GRANT \\
\hline 00120 & $11 \mathrm{c}$ & 015 & 1 & & SUPPLEMENTAL GRANT \\
\hline
\end{tabular}

Figure 32. - GIPSY dictionary for the Grant-in-Aid Programs File. 
PAGE UL

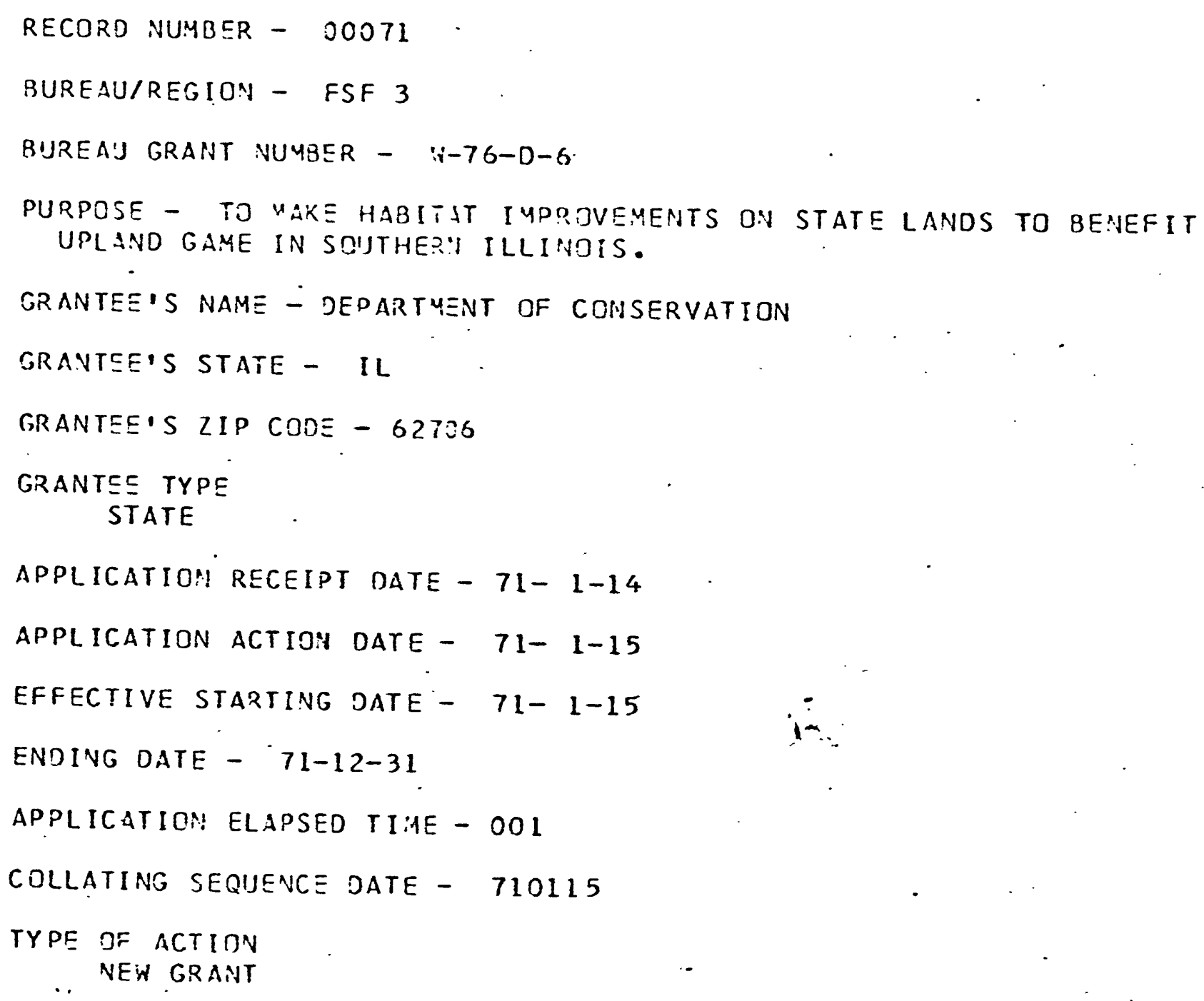

66 
Title: Working file

Sponsor: U. S. Department of the Interior

Office of Management Research

Washington, D. C. 20240

Contact: Lora Dugard, (202) 343-6191

Status of application: Pilot file

Objectives: To provide a working file to test and experiment with potential applications of GIPSY.

File organization: Often a potential user of GIPSY wishes to set up an experimental file. A GIPSY dictionary containing 90 labels and space for a records fize has been established to allow the user to test the system with a minimum of effort on his part.

Users: Office of Management Research 
INTERNAL EXTERNAL SPACING OPTION USASI CLEAR TEXT

FORM- ABST DICTSOMARY LISTING

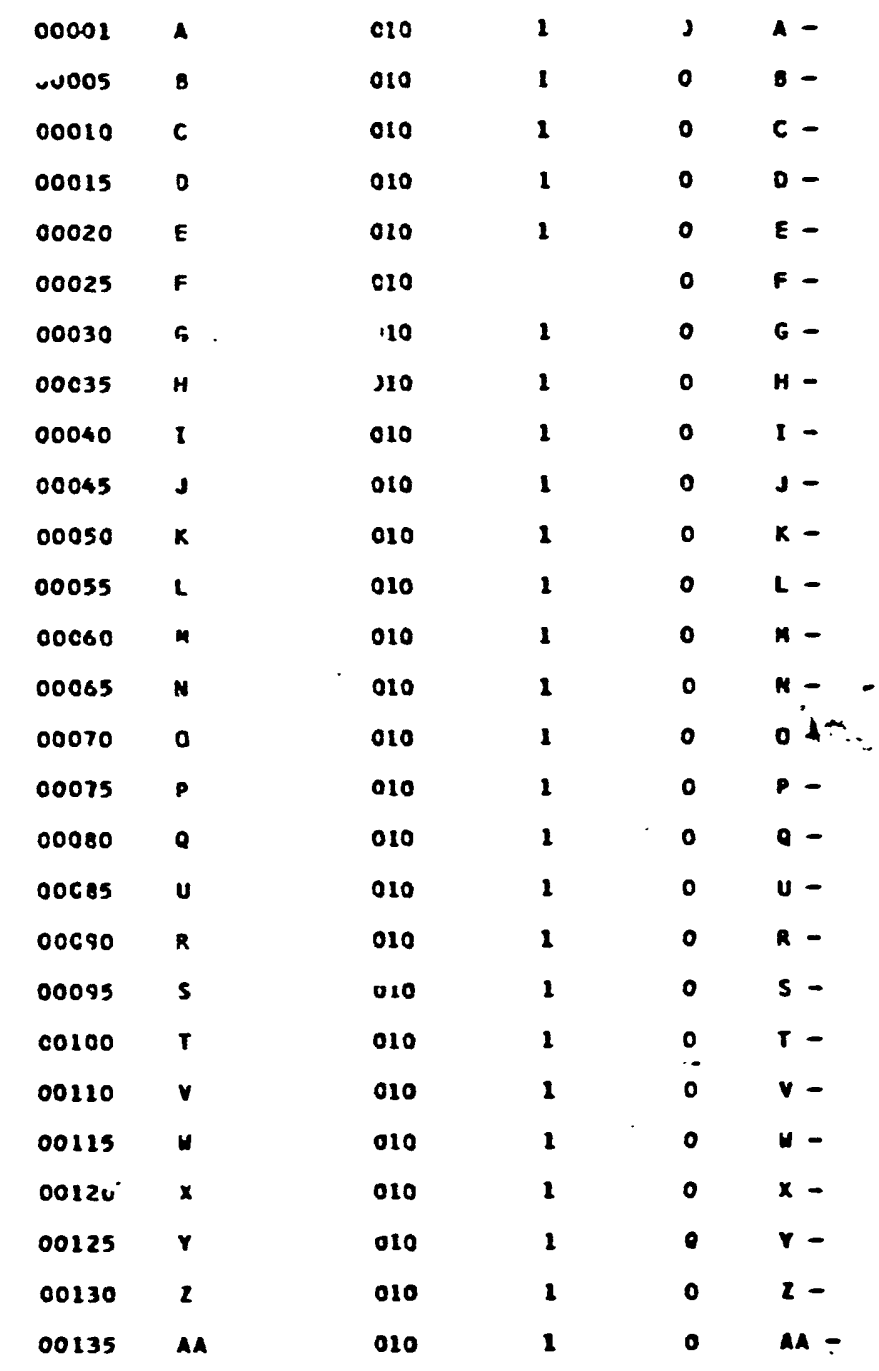

Figure 34. -- GIPSY dictionary for the Working file. 
Title: ocs Platform File

Sponsor: U. S. Geological Survey

Conservation Division, Branch of. Oil

and Gas operations

Washington, D. C. 20242

Contact: Richard Krahl, (202) 343-4528

Status of application: Pilot file (inactive)

objectives: To provide current data on the status of more than 1800 oil and gas platforms in the Gulf of Mexico. The drilling and production operations which take place on these platforms are under the supervision of the

Survey's Outer Continental Shelf Lease Management system.

Source documents: OCS platform descriptions and platform

lists.

File organization: Each record may contain up to 25 data elements. These include the platform location (latitude and longitude and area-block number), lease number, company (operator), number of holes, number of zone completions, a list of major production equipment, and date of last inspection.

Users: Engineers and Field Inspectors in the Conservation Division.

Size of file: The pilot file contained information on 25 platforms.

problems: The chief problem encountered in building the pilot file was assembling and editing the data. The conservation Division decided to adopt a fixed-field, fixed-length format for the platform file and dispense with the equipment lists in order to facilitate implementation. The QUERY retrieval system has proved very useful in compiling statistical sumearies from the fixed-length file. Eventually, the ocs platform file will be maintained on NIPS together with the oCS well file and other oCs lease management information. 


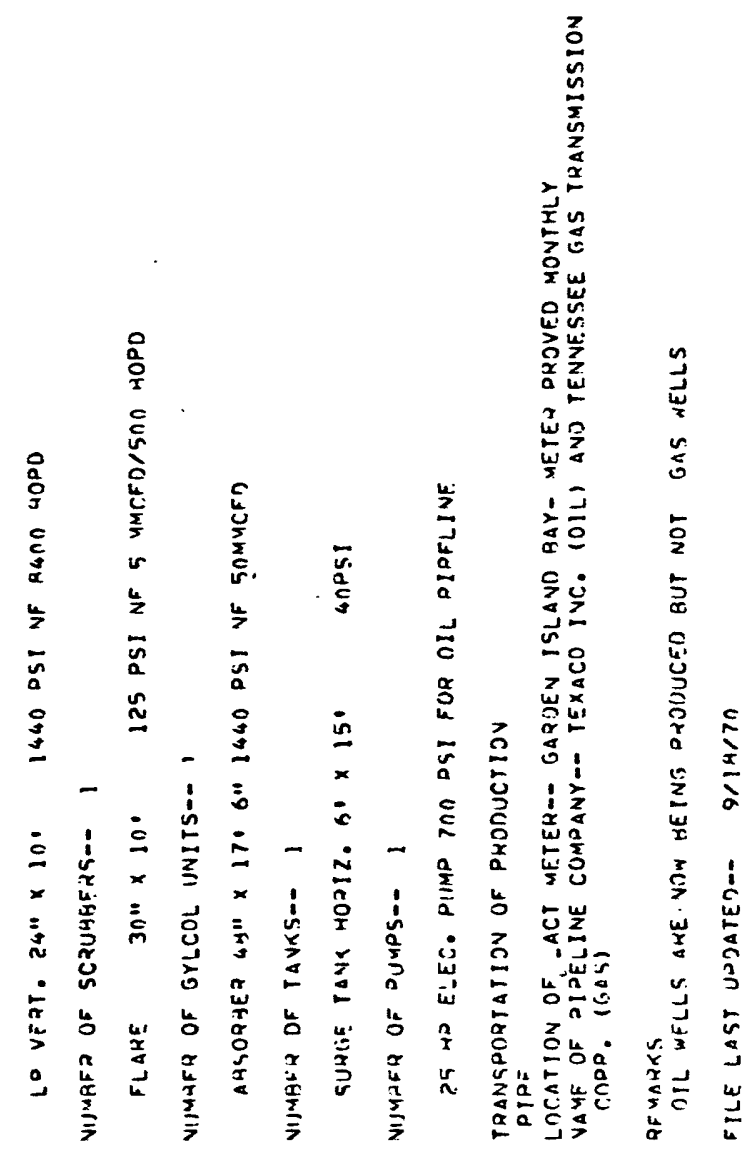

0
-1
-1
4
$E$
4
0
4
4
0
-1
0
0
0
0

委

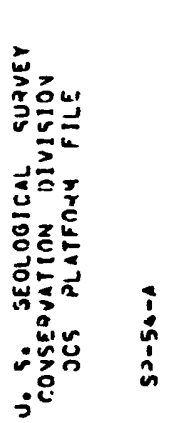

$\dot{v}$
$\grave{a}$
$\vec{a}$
$\breve{a}$
$a$
$a$
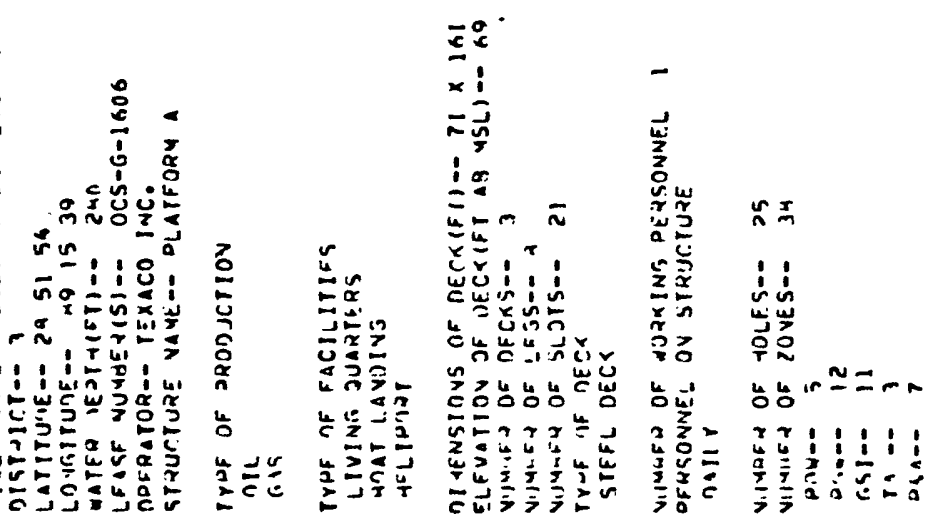

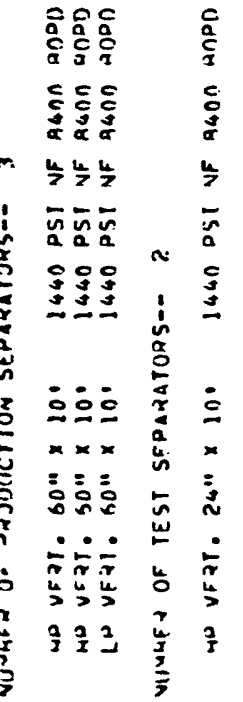


Title: OCS Events File

Sponsor: U. S. Geological Survey

Conservation Division, Branch of oil

and Gas Operations

Washington, D. C. 20242

Contact: Richard Krahl, (202) 343-4528

Status of application: Operational file

Objectives: To provide detailed information on the occurrence, circumstances, and damages caused by blowouts, Eires, explosions, and other accidents involving oil and gas operations on the outer Continental shelf of the Gulf of Mexico. The results of accident investigations, company

- reports, pollution reports, and pollution sighitings are periodically summarized to monitor the frequency of various types of events and their causes.

Source documents: Monthly Engineering Reports and accident investigations.

File organization: A record may contain up to 167 data elements including the location and date of the event, type of event, principal and secondary causes, the amount and type of pollution, number of injuries, dollars damages, lease number, name of operator (company), narrative description of event.

Users: U. S. Geological Survey engineers and other Federal agencies interested in environmental protection and safety.

Size of file: The file contains 200 event descriptions reported since. 1967 . 


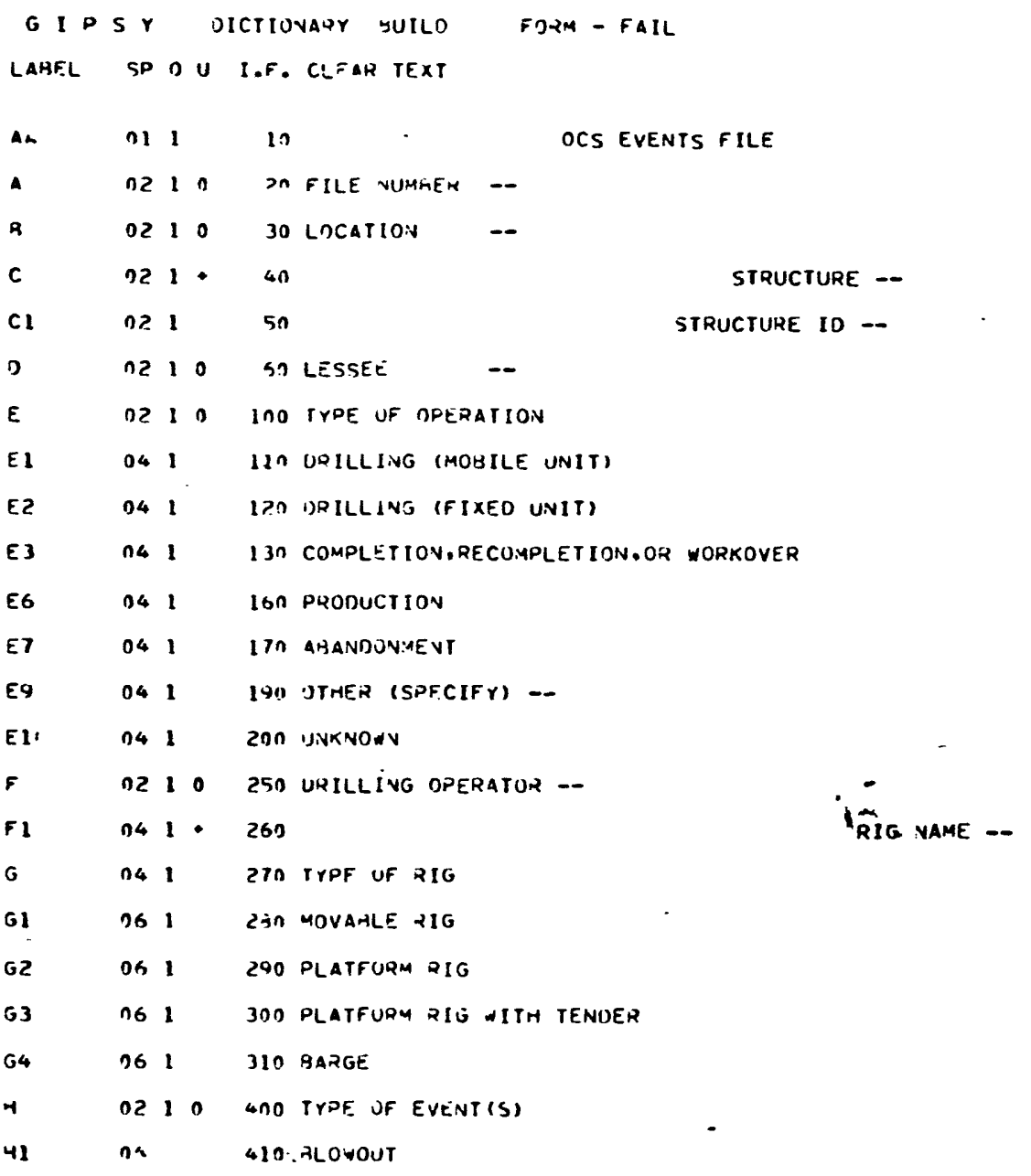

Figure 36. - GIPSY dictionary for the ocs Events file. 


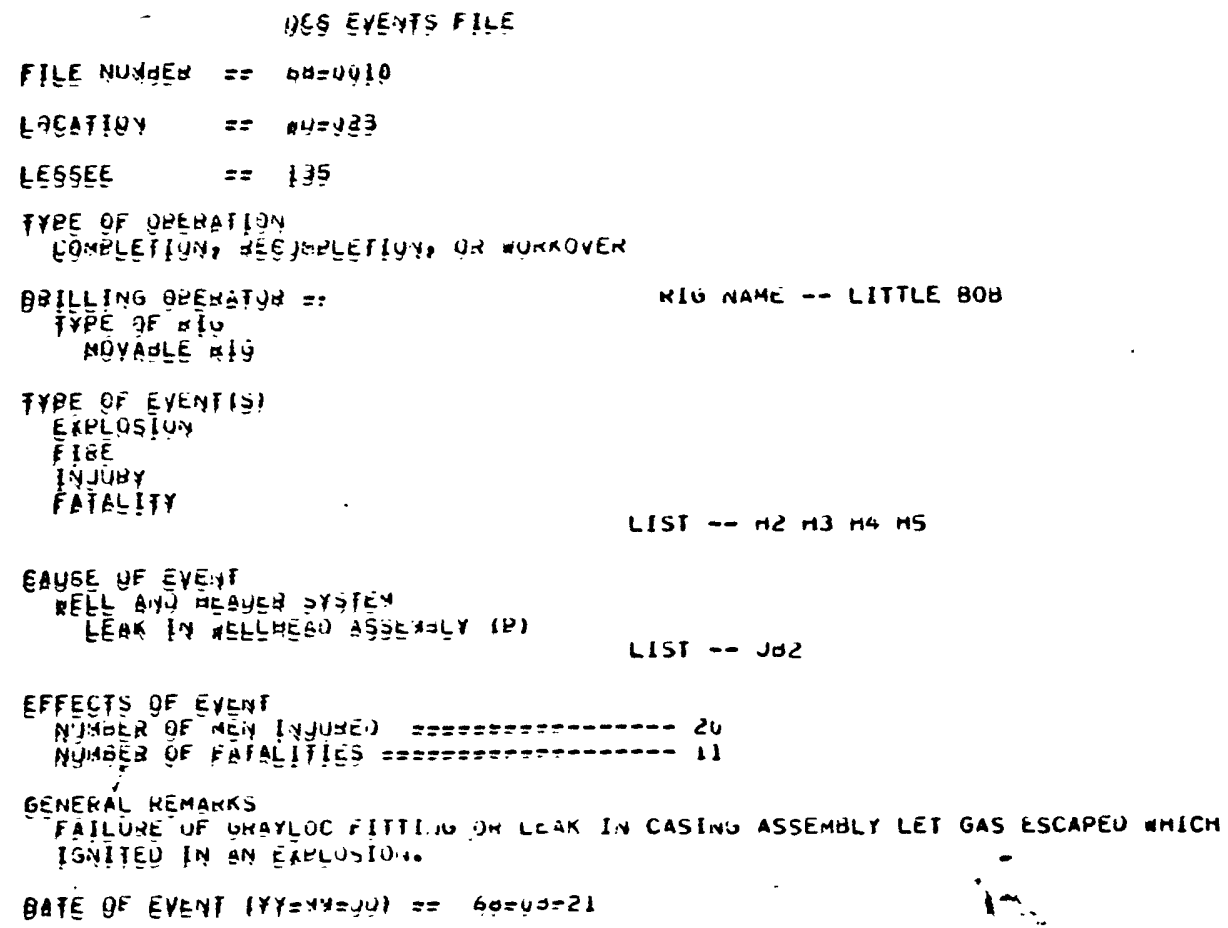

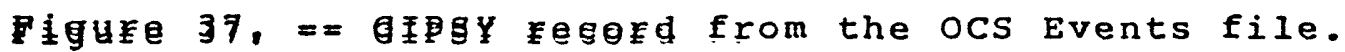


Title: WRD Project File

Sponsor: U. S. Geological survey

Water Resources Division

Washington, D. C. 20242

Contact: Robert A. Perry, (202) 343-2595

Status of application: Operational file

objectives: To provide information to survey management on the objectives, progress, funding, manpower needs, and products of approximately 1300 Water Resources Division projects. Besides meeting a variety of management needs, the file is also used to answer Congressional, Federal, state, and public inquiries about the scope geographic distribution, and intensity of survey activities in the field of water resources.

Source documents: Project description form (USGS-WRD Form 9-1686-B-G) which are keyboarded on an IBM Magnetic Tape/ selectric typewriter.

File organization: Each record may contain approximately 900 or more data elements depending primarily upon the complexity of funding. Major areas covered by the project description are listed below: project number, title (including a short title used in project listings), location, description of the problem, objectives, approach, anticipated benefits, manpower (including grade and specialty) need for additional manpower, type of project, fields of study, ppBs codes, use of data, distribution of data collection, anticipated information products, index terms (descriptors), distribution of work activities, fiscal data by type and source for a five-year period (PPBS planning period), number of data collection stations operated by type, progress and significant results, plans, project status, and reports published.

Users: Survey management. 
Size of file: At present the file contains 100 project records.

Problems: Input of a sizable amount of textual material present in this file has been handled by using IBM Magnetic Tape/Selectric typewriters to keyboard the data. The MT/ST tapes are later converted to EBCIDIC computer codes on 9-track magnetic tape, the data formatted, and the GIPSY records built.

In several instances use was made of fixed field formats within the GIPSY record. This was necessary, in the case of fiscal information, to avoid large numbers of labels in the dictionary. However, it limits the amount of information on which to base retrievals. Extensive use is made of other computer programs to process the data selected during a GIPSY search to perform statistical analyses of numeric data and to produce reports.

$$
1+
$$


(iD)

(müA

i $) 71$
U.S. GEOLOGICAL SURVEY

WATER RESOURCES DIVISION

PROJECT DESCRIPTION - PART A
Project no.

Former

Project no.

\section{Project number Al}

$F \varphi \perp G C L$

Type of funds

(Circle one or more) (!a)

Proposal no.

region

Project title $\mathrm{A24}$

a) Short title $\mathrm{A} 2 \mathrm{~A} 4$

$\begin{array}{llll}\text { Region } & \text { A3A } & \text { ACR } & 1 \\ \text { (Circle } & \text { A3M } & \text { MCR } & 2 \\ \text { one and } & \text { A3R } & \text { RMR } & 3 \\ \text { place } & \text { A3P } & \text { PCR } & 4 \\ \text { number } & \text { A3W } & \text { WRD } & 5 \\ \text { in box) } & \square\end{array}$

(4) Office $\quad$ A4 4

City

$\square$ State

(5) Initial data $\mathrm{A} 4 \square \square \square \square \square \square$

(6) Revision date $\mathrm{A} 64 \underset{\mathrm{yr}}{\square} \underset{\mathrm{mo}}{\square} \underset{\text { day }}{\square}$

Approval date $+74 \square \underset{y r}{\square \square} \square_{\text {day }}$

by

$1 \%$

Approved by

(Signature)

\section{Problem B1}

Location BIA

Objectives B2

10) Approach B3

Figure 38. - Input document for the WRD Project file. 




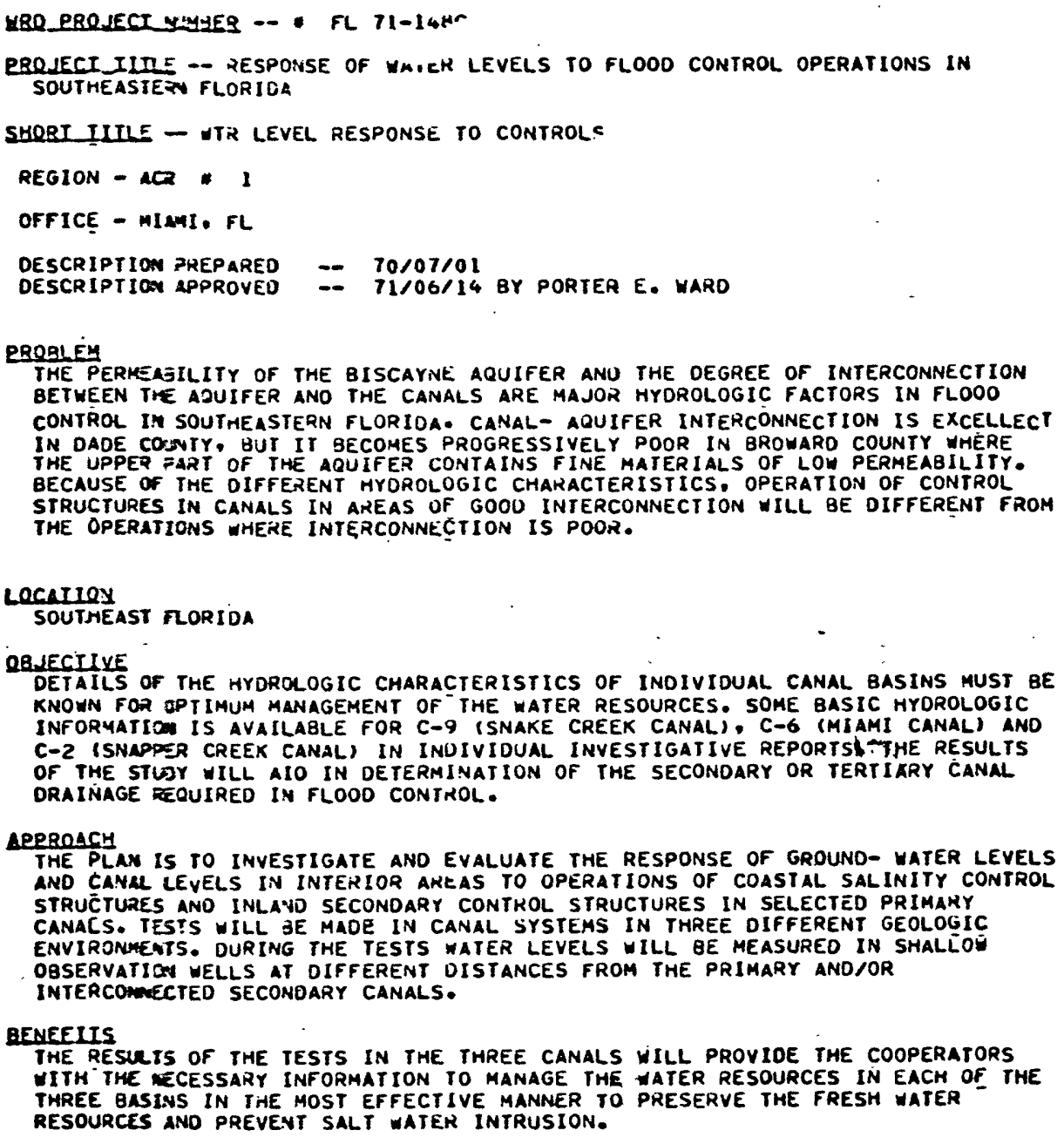
KNOWN FOR OPTIMUM MANAGEMENT OF THE WATER RESOURCES. SOME BASIC HYDROLOGIC INFORYATIO IS AVAILABLE FOR C-9 (SNAKE CREEK CANAL). C-6 (MIAMI CANAL) AND C-2 (SNMPPER CREEX CANAL) IN INUIVIDUAL INYESTIGATIVE REPORTSLTTHE RESULTS OF THE STLOY UILL AIO IN DETERMINATION OF THE SECONDARY OR TERTIARY CANAL DRAINAGE REOUIRED IN FLOOD CONTROL.

\section{APPROACH}

THE PLan is to investigate and evaluate the Response of ground- water levels AND CANRL LEVELS IN INTERIOR AKEAS TO OPERATIONS OF COASTAL SALINITY CONTROL STRUC̄TURES ANO INLAVD SECONDARY CONTHOL STRUCTURES IN SELECTED PRIMAKY CANACS. TESTS WILL JE MAOE IN CANAL SYSTEMS IN THREE DIFFERENT GEOLOGIC ENVIRONUENTS. DURING THE TESTS WATER LEVELS WILL BE MEASUREO IN SHALEOH OBSERVATIOT WELLS AT DIFFERENT DISTANCES FROM THE PRIMARY AND/OR INTERCONECTED SECONOARY CANALS.

\section{BENEEIIS}

THE RESULTS OF THE TESTS IN THE THREE CANALS WILL PROVIDE THE COOPERATORS ITH THE ECESSARY INFORMATION TO MANAGE THE HATER RESOURCES IN EACH OF THE THREE BASINS IN THE MOST EFFECTIVE MANMER TO PRESERVE THE FRESH WATER RESOURCES AND PREVENT SALT WATER INTRUSION.

Figure 40. -- GIPSY record from WRD Project file. 


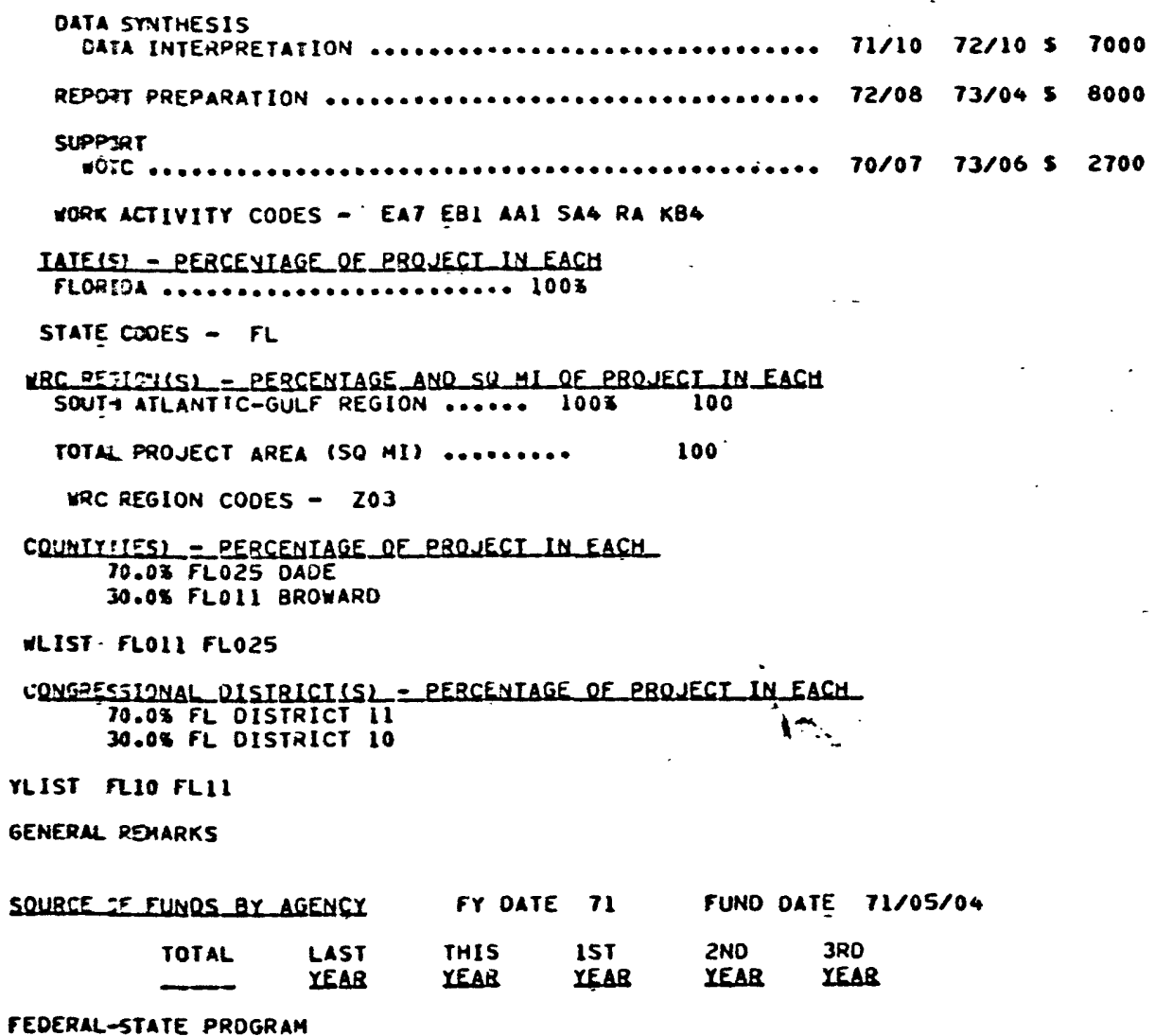

FLES CENTRAL AND SOUTHERN FLA FLOOD CONTROL OIST

$\begin{array}{rrrr}\text { REP } & 5000 & 5000 & 5000 \\ \text { WRO S } & 5000 & 5000 & 5000 \\ -5 & 10000 & 10000 & 10000 \\ -5 & .0000 & 10000 & 10000\end{array}$

Rigure 40. - (continued) 


\author{
MINUTES \\ GIPSY USERS' CONFERENCE
}

On May 12, 1971, a GIPSY users' conference was held in Washington, D. C. The host was the Department of the Interior. During this conference, users suggested various extensions and improvements to the program. Following the meeting, the Conference Chairman contacted some of the attendees and asked them to rank the suggestions in priority order. Following are. the suggestions, in priority groups, based on a sampling of attendees. Suggestions within a group are of equal rank.

I Highest Priority

1. Generic Labels. Provide synonomy or the ability to group or equate labels in the dictionary and at search time.

2. Periodicity. Provide for perioäic or fepeating label's or sets of labels for time dependent aata. Examples: a set of labels for an empioyee's previous employment history or dates of reading and measurements of well head pressures at a gas well.

3. Updating. Need generally improved update procedures incluaing the ability to update individual records through the record ID (index sequential technique), the ability to update directly from fixed field cards, and the ability to update all records in a file easily.

4. Conversion. A generalized utility program for converting existing fixed field, fixed record length files to GIPSY.

II Ist Intermediate Priority

5. Documentation. Prepare a 4-part GIPSY manual:

A. Basic User's Manual. Distinguish clearly between batch and TP versiors and provide card layouts for batch versions.

B. File Maintenance. Include conversion of existing files, builciing new files, updating, back up files and procedures. 
C. System Details. Maximums, minimums, limitations on commands, JCL, record lengths, common system error messages and probable causes, GIPSY error messages and causes.

D. Utilities. Helpful hints, unusual techniques, interface with other programs, conversion programs, MT/ST, phototypesetting---get input from. users.

6. Reentrant Program. Nake TP GIPSY reentrant so users can share a single GIiSY partition in core.

7. UC/LC. Provice, for upper and lower case characters in storage and printout, but with search based on single case.

8. Secondary Indexes. Allow the user to build secondary indexes (inverted files) on selected labels to improve search time.

9. Multiple SRF's. Allow the user to build, store, and call SRF's with Questran commanas and without changing JCL.

10. Multiple Output Files. Provide for more than one output file in COPY.

11. RPG. Provide standard report generator capability, Iinked to COPY, i.e., level controls, columnar sums, counts, format controls.

12. COPY Printed Output. Provide for title page, column headings on each page, and page numbers.

13. COPY, Clear Text. Access clear text from the Dictionary.

14. COPY, Variable Length. Output variable length fields and records, including user inserted labels, delimiters, edit codes-for typesetting and related.applications:

15. Duplicate Records. Scan for duplicate records and delete the duplicate record(s) that occur first in the file. 


\section{Lowest Priority}

16. COPY Parameters. Increase the limit on the number of COPY parameters beyond the present 100.

17. Logic Weight. Implement the logic weight statement

18. Runaway Printout. Provide for setting a limit on the number of recoras to be printed in the batch mode.

19. Space and Level. Separate the space and level controls in the dictionary.

20. Intra-Record Sum. Extend the sum capability to summing labels within a field.

21. Dictionary. Explain which dictionary fields are left or right justified.

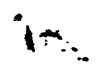

V Special recommendations which affect a single agency or which are not rarkable in priority order.

22. On Line Update. Provide for direct on-line updating througi IE: 2260 CRT terminals.

23. DUM. Provide a fix for the DUMP utility in use at USGS. This program does not clear the track overflow byte.

24. GIPSY Newsletter

VI Comments

GIPSY's principal advantage is its simplicity. In adding these extensions, we may be moving from a useroriented to a programmer-oriented system. The recommendations made at the user's conference will extend to versatility of the progran and are wholly desirable. However, they should be optionally available to the sophisticatea user or programer and transparent, or simply not there, for the general user.

The ranking of the recommendations was based on a sampling of attendees. If any attendee disagrees with the ranking, please contact Dr. Sweeney at the University of Oklahoma directly. 
I would like to thank Darrel Knoll of the National Oceanographic Data Center, David W. Moody of the Water Resources Division; U. S. Geological Survey, and Ljubo Lulich of the Water Resources Science Information Center for their assistance in organizing the user's conference.

Olaf Kays

U. S. Geological Survey

Washington, D. C. 20242

- Conference Chairman

i... 


\section{SELECTED REFERENCES}

Addison, C. H., Shields, R. W., and Sweeney, J. W., 1969, GIPSY - Generalized Information Processing System; applications description: Univ. Oklahoma Information science ser. Mon. 4.

Blackwell, P. W., Morrison, J. L., and Smith, W. E., Jr., 1969, GIPSY computer retrieval of geologic literature: Oklahoma Geology Notes, v. 29, p. 6-14.

Office of Oil and Gas, 1971, Oil and Gas Field study: two-year progress report: Office of oil and Gas Tech. Rept. - 71-1, $237 \mathrm{p}$.

Office of Water Resources Research, 1966, Water resources thesaurus: U. S. Department of the Interior, office of Water Resources Research, Washington, D. C., 237 P.

U. S. Geological survey, 1967, Guide to indexing bibliographies and abstract journals of the U. S. Geological Survey: U. S. Geol. Survey, washington,.D. C.

Water Resources Scientific Information Center, 1971, Legal aspects of water pollution in New England; a bibliography: U. S. Department of the Interior, office of Water Resources Research, Water Resources Scientific Information Center, WRSIC 71-213. 